\title{
Environmental Impacts—Coastal Ecosystems
}

\author{
Jan P. Bakker, Andreas C.W. Baas, Jesper Bartholdy, Laurence Jones, \\ Gerben Ruessink, Stijn Temmerman and Martijn van de Pol
}

\begin{abstract}
This chapter examines the impacts of climate change on the natural coastal ecosystems in the North Sea region. These comprise sandy shores and dunes and salt marshes in estuaries and along the coast. The chapter starts by describing the characteristic geomorphological features of these systems and the importance of sediment transport. Consideration is then given to the role of bioengineering organisms in feedback relationships with substrate, how changes in physical conditions such as embankments affect coastal systems, and the effects of livestock. The effects of climate change - principally accelerated sea-level rise, and changes in the wind climate, temperature and precipitation - on these factors affecting coastal ecosystems are then discussed. Although the focus of this chapter is on the interaction of abiotic conditions and the vegetation, the potential impacts of climate change on the distribution of plant species and on birds breeding in salt marshes is also addressed. Climate impacts on birds, mammals and fish species are covered in other chapters.
\end{abstract}

Electronic supplementary material Supplementary material is available in the online version of this chapter at 10.1007/978-3-31939745-0_9.

J.P. Bakker $(\bowtie)$

Groningen Institute for Evolutionary Life Sciences, University of Groningen, Groningen, The Netherlands

e-mail: j.p.bakker@rug.nl

A.C.W. Baas

Department of Geography, King's College London, London, UK e-mail: andreas.baas@kcl.ac.uk

J. Bartholdy

Department of Geosciences and Natural Resource Management, University of Copenhagen, Copenhagen, Denmark

e-mail: jb@ign.ku.dk; jb@geo.ku.dk

L. Jones

Centre for Ecology and Hydrology, Bangor, UK

e-mail: 1j@ceh.ac.uk

\section{G. Ruessink}

Department of Physical Geography, Faculty of Geosciences, Utrecht University, Utrecht, The Netherlands e-mail: B.G.Ruessink@uu.nl

\section{S. Temmerman}

Ecosystem Management Research Group, Antwerp University, Antwerp, Belgium

e-mail: stijn.temmerman@uantwerpen.be

M. van de Pol

Department of Evolution, Ecology and Genetics, Research School of Biology, Australian National University, Canberra, Australia e-mail: martijn.vandepol@anu.edu.au

M. van de Pol

Department of Animal Ecology, Netherlands Institute of Ecology (NIOO-KNAW), Wageningen, The Netherlands

e-mail: M.vandePol@nioo.knaw.nl 


\subsection{Introduction}

This chapter examines the impacts of climate change on the natural coastal ecosystems in the North Sea region. These comprise sandy shores and dunes and salt marshes in estuaries and along the coast. The chapter starts by describing the characteristic geomorphological features of these systems and the importance of sediment transport. Consideration is then given to the role of bioengineering organisms in feedback relationships with substrate, how changes in physical conditions such as embankments affect coastal systems, and the effects of livestock. The effects of climate change - principally accelerated sea-level rise, and changes in the wind climate, temperature and precipitation — on these factors affecting coastal ecosystems are then discussed. Although the focus of this chapter is on the interaction of abiotic conditions and the vegetation, the potential impacts of climate change on the distribution of plant species and on birds breeding in salt marshes is also addressed. Climate impacts on birds, mammals and fish species are covered in other chapters.

\subsection{Geomorphology of Sandy Shores and Coastal Dunes}

\subsubsection{Distribution and Composition}

\section{Andreas C.W. Baas, Gerben Ruessink}

The North Sea Basin is ringed by sandy shores and coastal dune fields developed from sedimentary deposits on nearly all sides, except the north-east. The sandy shores include most of the Belgian, Dutch, and Danish coasts as well as various parts of the English North Sea coast, where they alternate with muddy and soft rocky coasts, as well as gravel-dominated coastlines. Extensive dune fields are found along the entire coast of Belgium and the Netherlands, along the sequence of Wadden Sea barrier islands to the Elbe Estuary and up along the entire west coast to the northwest coast of Denmark. These sandy shorelines and dune fields constitute a regional complex developed out of sediment delivered mainly from the Rhine-Meuse delta into the coastal zone, transported via longshore currents following the sweep of the semi-diurnal tide anti-clockwise around the south-eastern coastlines of the North Sea Basin, and being accumulated and driven inland from the beaches by the dominant westerly winds. Coastal dunes along the western Danish coastline cover approximately $800 \mathrm{~km}^{2}$ (Doody and Skarregaard 2007), while 254 of the $350 \mathrm{~km}$ of the coastline of the Netherlands is fronted by approximately $450 \mathrm{~km}^{2}$ of coastal dune fields extending in some places up to $11 \mathrm{~km}$ inland (Doing 1995). Sand dunes also fringe most of the $65 \mathrm{~km}$ long coastline of Belgium, covering approximately $38 \mathrm{~km}^{2}$ and with widths of a few kilometres to less than $100 \mathrm{~m}$, although more than $50 \%$ of the coast has been urbanised (Herrier 2008). The western side of the North Sea Basin is also lined by dune fields along the east coast of the United Kingdom, although these are of a less continuous nature (Doody 2013). Significant dune presence can be found along the northeast of East Anglia, along most of the Lincolnshire coast, isolated stretches along the Yorkshire and Northumbrian coast, and more extensive dune fields along the south-eastern coast of Scotland. The North Sea coastal dunes in the UK are smaller and less extensive than their continental counterparts, because sediment delivery to the coastal zone is from smaller regional catchments (the Thames, the Wash, the Humber), and the easterly winds that propel the dune development are generally weaker and less frequent. A tally of dune fields between Dover and Shetland included in the Sand Dune Vegetation Survey of Great Britain (Dargie 1993; Radley 1994) amounts to $93 \mathrm{~km}^{2}$ (although a significant proportion of dune fields in Scotland are managed as golf courses).

\subsubsection{Current Stressors and Management}

In general, sandy shores are alongshore elongated sand bodies whose yearly to decadal evolution is primarily driven by waves and wind. Cross-shore and/or alongshore gradients in sand transport cause coastal morphology to change, reflected by erosion or accumulation of sand. According to a recent EU study of coastal geomorphology and erosion (Eurosion 2004), a large proportion (20-26\%) of the North Sea sandy shores is currently experiencing erosion and, as a consequence, is heavily affected by human activities, such as the presence of hard coastal defence measures (seawalls, groynes) or of regular sand nourishments. It is, however, important to realise that coastal erosion or accretion may vary on a wide range of temporal and spatial scales. A study by Taylor et al. (2004), for example, has shown that the bulk of the North Sea coast of England steepened due to erosion and coastal squeeze over the course of the entire 20th century. On a decadal scale, a coast may gently (typically, a few metres per year) accrete or erode, which is often due to small but persistent gradients in alongshore sediment transport. Shorter-term variations around the decadal trend are often significantly larger, and can be due to episodic erosion events (e.g. dune erosion during a storm) or to the alongshore migration of sand bodies (e.g. Ruessink and Jeuken 2002). Coastal changes may be due to long-period variability and oscillations in wave and storm climate unconnected to climate change (Hadley 2009). 
The vast majority of coastal dune systems around the North Sea Basin are tightly managed and controlled for the purpose of various socio-economic and ecoservices (see Electronic (E-)Supplement S9). Along the coasts of Belgium and the Netherlands especially, the main purpose of management has been to preserve and, where possible, expand the sand volume of the foredunes to provide coastal flooding protection and more than $40 \%$ of the foredunes have been artificially preserved or established (Arens and Wiersma 1994), usually by dense marram grass Ammophila arenaria planting. In the past two decades a more eco-centred concept has slowly been adopted to allow and encourage limited geomorphic re-activation of wind-blown erosion and bare-sand patches to develop a more varied and species-rich coastal dune environment (Arens and Geelen 2006). Other management practices include grazing activities on grey dunes to combat overgrowth of coarse shrubs (e.g. sea-buckthorn Hippophae rhamnoides) to preserve biodiversity (Boorman and Boorman 2001) as well as grazing and sod-cutting on species-rich dune grasslands to prevent grass-encroachment due to nitrification from atmospheric nitrogen deposition (Kooijman and Van der Meulen 1996).

\subsubsection{Expected Impacts of Climate Change}

Climate change could affect both marine and aeolian boundary conditions. In particular, climate change impacts might be felt through accelerated sea-level rise (SLR) and in modifications in the number, severity and location of extra-tropical storms, with associated changes in wind, wave, precipitation and temperature patterns. The potential consequences of climate change on the North Sea Basin sandy shores and coastal dune systems may be separated into direct geomorphic impacts relating to sea forcing (accelerated SLR and changes in wave climate), wind forcing (changes in weather patterns and wind climate), and potential changes in vegetation character and distribution related to overall climatic changes (temperature and precipitation). Consequences for the vegetation are discussed in Sect. 9.3. Some of these direct impacts may be aggravated by adjustment and intensification of human exploitation and management practices.

\subsubsection{Sea-Level Rise and Wave Characteristics}

Historic tide gauge data for the North Sea region from 1900 to 2011 show a mean SLR of $1.5 \pm 0.1 \mathrm{~mm} \mathrm{year}^{-1}$ (Wahl et al. 2013), slightly below the global mean SLR of $1.7 \pm 0.3 \mathrm{~mm} \mathrm{year}^{-1}$ during the latter half of the 20th century (Church and White 2006). Whereas SLR globally appears to have accelerated to $3.3 \pm 0.4 \mathrm{~mm} \mathrm{year}^{-1}$ from 1993 to 2009 (Ablain et al. 2009, see also Chap 3), the Wahl et al. (2013) study suggests that North Sea SLR acceleration in recent decades is not abnormal, but comparable to that of other periods in the last 200 years. Within the North Sea region local differences have been recorded (as indicated in Table 9.1 in Sect. 9.6.1). While the Intergovernmental Panel on Climate Change (IPCC) in its latest assessment (Van Oldenborgh et al. 2013) projects a global mean SLR of $74 \mathrm{~cm}$ by 2100 (at a rate of $11 \mathrm{~mm} \mathrm{year}^{-1}$ ), for the 'business-as-usual' Representative Concentration Pathway scenario (RCP8.5), other studies that include semi-empirical forcing models have projected SLR of between 30 and $180 \mathrm{~cm}$ by 2100 , depending on the model variant (Nicholls and Cazenave 2010). Recent high-end projections suggest that a $1.25 \mathrm{~m} \mathrm{SLR}$ in the North Sea may be possible by 2100 (Katsman et al. 2011), although the exact magnitude of the rise strongly depends on underlying modelling assumptions.

Studies on the significant wave height $H_{s}$ in the North Sea (e.g. Grabemann and Weisse 2008; De Winter et al. 2012) project no to small changes along the Dutch-German coast, with magnitudes depending on the type of general circulation model (GCM) or regional climate model (RCM) used and the particular greenhouse-gas emissions scenario adopted, as for example in Fig. 9.1. For example, Grabemann and Weisse (2008), who used the HadAM3H and the ECHAM4/OPYC3 GCM with SRES scenarios A2 and B2, projected a $0.1-0.3 \mathrm{~m}$ increase in the 99th percentile of $H_{s}$ in front of the Dutch coast by the end of the 21st century, while De Winter et al. (2012), using the ECHAM5/MPI-OM and the SRES A1B scenario, found no detectable change in mean wave conditions. This would seem to indicate that model uncertainty in the prediction of $H_{s}$ is larger than the emission-induced uncertainty, as was found in general for global projections in the latest IPCC assessment (Van Oldenborgh et al. 2013), which reports low confidence in wave projections because of "uncertain storm geography, limited number of model simulations, and the different methodologies used to downscale climate model results to regional scales".

It is important to consider that the wind, and hence wave climate, shows strong natural variability, which poses a difficulty in detecting climate-change induced trends that are smaller than this natural variability. This is especially relevant to wind and wave conditions with high return periods (for example, 1:1-1:10-year return values, or even rarer) that may be most relevant to coastal erosion. Using the 17-member ESSENCE ensemble (Sterl et al. 2008), De Winter et al. (2012) projected a 0.3-0.6 s decrease in the annual wave period $T$ in front of the Dutch coast for the period 2071-2100, as well as a shift in the wave direction of the annual $H_{s}$ maxima from north-west to south-west. The decrease in $T$ is induced by this wave-angle shift and associated shifts in the fetch; accordingly, the same shift may lead to an increase in $T$ elsewhere in the North Sea Basin. $H_{s}$ and $T$ with higher return periods, up to 10,000 years, were 
Table 9.1 Regional variation in mean sea-level rise (SLR) within the North Sea region (see also Chap. 3)

\begin{tabular}{|c|c|c|c|}
\hline Area & SLR mm year ${ }^{-1}$ & Period & Source \\
\hline \multirow[t]{2}{*}{ Europe } & 1.7 & $1900-2000$ & EEA (2012) \\
\hline & 3 & $1990-2010$ & EEA (2012) \\
\hline Wadden Sea & $1-2$ & $1900-2000$ & Oost et al. (2009) \\
\hline UK east coast & $0.5-2.5$ & $1900-2000$ & Woodworth et al. (2009) \\
\hline English channel & $0.5-2.5$ & $1900-2000$ & Haigh et al. (2011) \\
\hline The Netherlands & 2.5 & $1900-2000$ & Katsman et al. (2008) \\
\hline \multirow[t]{3}{*}{ German bight } & $1.2-2.4$ & $1937-2008$ & Wahl et al. (2011) \\
\hline & $1-2.8$ & $1951-2008$ & Wahl et al. (2011) \\
\hline & $2.5-4.6$ & $1971-2008$ & Wahl et al. (2011) \\
\hline Lower Saxony, Germany & 1.7 & $1936-2008$ & Albrecht et al. (2011) \\
\hline Schleswig-Holstein, Germany & 2 & $1936-2008$ & Albrecht et al. (2011) \\
\hline \multirow[t]{2}{*}{ Skallingen, Denmark } & 2.3 & 1931-1999 & Bartholdy et al. (2004) \\
\hline & 5 & 1980-2000 & Bartholdy et al. (2004) \\
\hline
\end{tabular}



Fig. 9.1 Increase in the height $(\mathrm{m})$ of a 50-year return period extreme water level event, due to combined changes in atmospheric storminess, mean sea-level rise, and vertical land movements, for the SRES A2 scenario, based on the HadRM3H regional atmospheric model and the POL storm-surge model (Lowe and Gregory 2005)

not projected to change significantly at the $95 \%$ confidence level. This also applies to storm surges with similar high return periods (Sterl et al. 2008). In a recent CMIP5 model-comparison study of wind extremes in the North Sea Basin, De Winter et al. (2013) found no changes in annual maximum wind speed or in wind speeds with lower return frequencies for the 2071-2100 period; however, they did find an indication that the annual extreme wind events are coming more often from westerly directions. Thus, these CMIP5 results are not notably different from all earlier CMIP3 (e.g. De Winter et al. 2012) model projections.

The quantitative prediction of the response of sandy shores to climate-change induced effects in the boundary conditions is still under development. The most often used model for the response to accelerated SLR is the Bruun rule (Bruun 1962), a simple two-dimensional mass conservation principle that predicts a landward and upward displacement of the cross-shore profile with SLR (Fig. 9.2). Coastal recession is simply expressed as the product of SLR and the active profile slope, giving typical projected recession distances of 50-200 $\mathrm{m}$ depending on profile slope. Although the Bruun rule was routinely used in past decades, its usefulness as a predictive tool is highly controversial (Pilkey and Cooper 2004). For example, the Bruun rule does not include any three-dimensional variability, such as found near engineering structures and tidal inlets, and can thus not be applied in areas with notable gradients in alongshore sediment transport. Also, the Bruun rule predicts sand to be moved offshore during SLR, while overwash and aeolian processes obviously transport sand onshore. Advances have been made in developing more comprehensive conceptual models for understanding and predicting shoreline change in terms of the so-called Coastal Tract (Cowell et al. 2003), but this concept has been aimed at time scales of hundreds to thousands of years. Other more realistic rule-based approaches for predicting shoreline change have been provided by Ranasinghe et al. (2012) and Rosati et al. (2013), but these have not yet been tested on North Sea sandy shores. Beach profile adjustments to accelerated SLR are more likely to involve significant alongshore components and variations as well as greater sensitivities to local changes in sediment budgets (Psuty and Silveira 2010). Even though projections of the North Sea wave climate suggest no to minor change, it is possible that accelerated SLR and changes in wave direction may still aggravate coastal erosion. A modelling study for the UK East Anglian coast, a site with notable alongshore variability in shelf bathymetry, illustrates that 
Fig. 9.2 Three potential cross-shore responses to sea-level rise (SLR): a Bruun-type response (much disputed) where sediment is redistributed to reach a new equilibrium beach profile; b reactivation, growth, and inland migration of foredunes; c vegetation cover becomes ineffective leading to a large-scale transgressive dune field (Carter 1991)

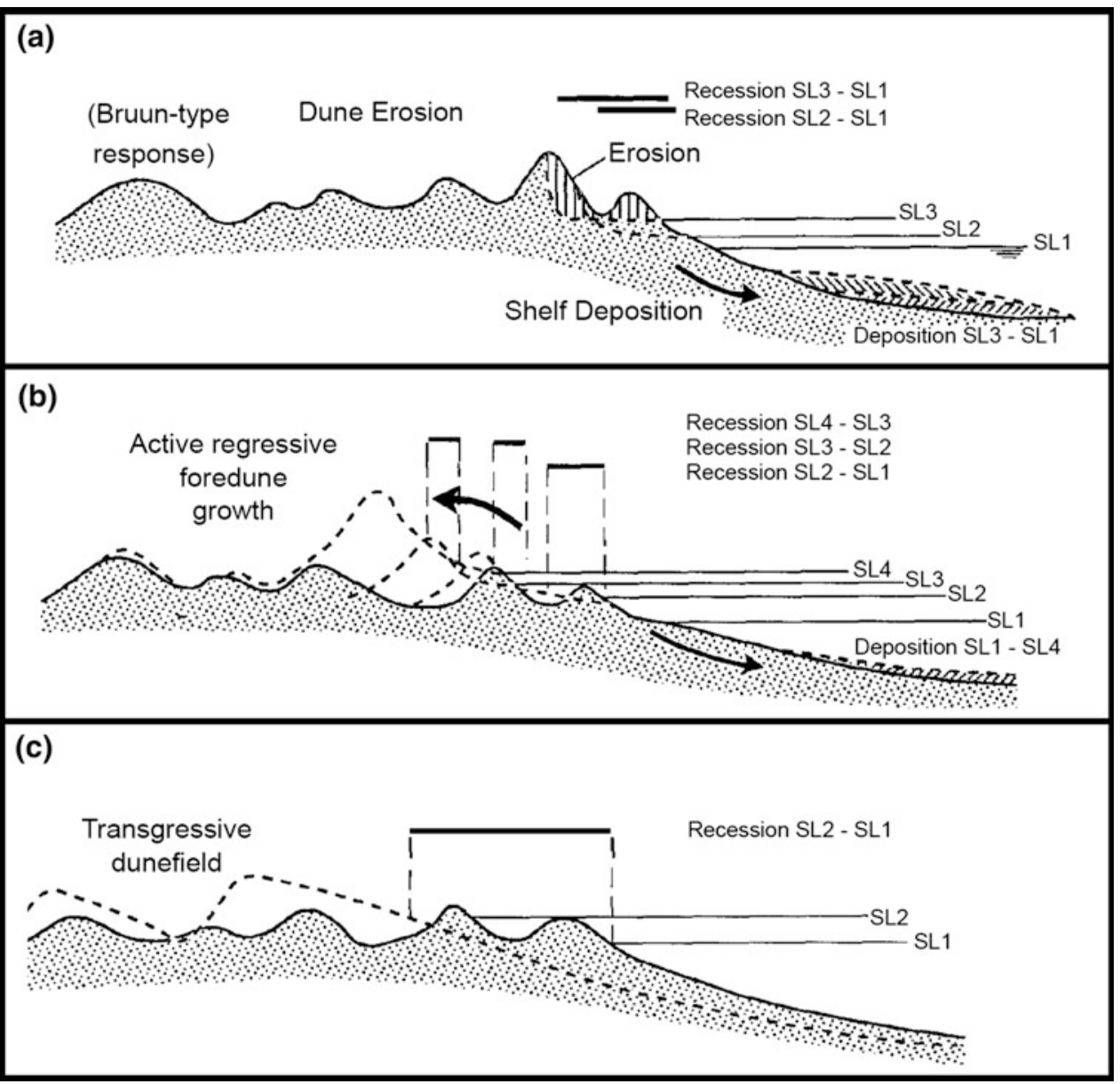

inshore wave statistics are sensitive to the trend in SLR and that frequency of occurrence of extreme inshore wave conditions may increase with SLR rates higher than $7 \mathrm{~mm}$ year $^{-1}$ (Chini et al. 2010). This, coupled with an increasing occurrence of high water levels by accelerated SLR, may lead to enhanced beach and dune erosion even if wind and wave characteristics remain unaltered under projected climate change; the same effect could also endanger the safety of existing hard coastal defence mechanisms. In a case study for the Dutch coast, De Winter (2014) projected an increase in dune erosion volume by up to $30 \%$ because of a 1-m SLR under unchanged extreme (1:10,000 year) wave conditions. The same case study also illustrated that a change in wave direction by several tens of degrees could lead to a similar increase in dune-erosion volumes as predicted for an approximately $0.4-\mathrm{m}$ rise in sea level, indicating that changes in wind and wave direction are also critically important to coastal response. Such directional changes will also affect the magnitude and, potentially, the sign of gradients in alongshore sand transport, and hence beach width. Current dune-erosion models are primarily based on data collected in laboratory experiments; extensive field validations have, however, not been performed. Furthermore, the models lack descriptions of post-storm coastal recovery by aeolian processes and thus provide an erosion-biased view of coastal evolution. Dunes and beaches are linked in a dynamic and complex sediment exchange system, where losses of sediment from foredunes during storms alternate with inter-storm deposition gains (e.g. Keijsers et al. 2014), potentially leaving the overall shoreline position unchanged in the long term. More frequent storm erosion of the foredune toe may therefore not necessarily result in permanent loss of sediment from the coastal system.

The precise response of the nearshore zone to climatic change and its consequent impact on adjacent coastal dunes is therefore ambiguous and probably subject to substantial regional variation, as in some areas the hydrodynamic boundary conditions may not change very much, while in other areas the coastal sediment budget system will be undergoing complex adjustments. Paradoxically, while sandy beaches in the worst case may get narrower and squeezed between human pressure and accelerated SLR (Carter 1991; Schlacher et al. 2007), the remobilisation and increased dynamics in sediment exchange across the nearshore profile as it is adjusting to SLR may in fact yield an opportunity for reinvigorating coastal dune development 
(Psuty and Silveira 2010), as illustrated in Fig. 9.2. Just as during the mid-Holocene, SLR and coastal regression may create opportunities for foredune expansion along some parts of the coastline. This may result from supply of increased amounts of sediment delivered from the adjusting beach profile into the coastal dune system, possibly aided by larger and more frequent storm breach of the dunes, and the potential for greater aeolian sand transport activity in the inland parts of the dune field. This type of landscape response does, however, require the availability of suitable accommodation space for the coastal dune system and in many regions a net landward migration of dunes is arrested by infrastructure and built environment, thus leading to a 'sand dune squeeze' (Doody 2013) and an eventual loss of dune habitat. Coastal squeeze also operates within sites, as the younger, more dynamic habitats including foredunes and yellow dunes may be squeezed against more stable fixed dune grassland, or scrub which occurs in older hind-dune areas. These successionally young habitats are particularly important for many of the dune rare species and, while it is possible for natural remobilisation to occur, it is unlikely under current climatic conditions, since dune mobility is strongly coupled to climate (Clarke and Rendell 2009).

\subsubsection{Wind Forcing}

As previously mentioned, an increase in storminess and associated changes in wind conditions may have implications for the potential of aeolian reactivation of coastal dunes, as well as the wind-blown transport of the additional sediment mobilised as part of beach profiles that are adjusting to accelerated SLR. Regional climate model projections by Beniston et al. (2007) suggest a $5 \%$ increase in the 90th percentile of daily maximum wind speed over most of the North Sea Basin in winter (Fig. 9.3), with storm winds coming from more north-westerly directions.

These projections conflict with the more recent prediction of more south-westerly storm winds by De Winter et al. (2012, 2013). The IPCC meanwhile indicates a "substantial uncertainty and thus low confidence in projecting changes in $\mathrm{NH}$ [northern hemisphere] winter storm tracks, especially for the North Atlantic basin" (Van Oldenborgh et al. 2013). The impact of any potential changes in wind climate on the coastal dune fields in the region has not been considered in detail. A shift in dominant wind direction may have a significant impact on the delivery of sediment from the beach into the foredunes due to changes in sub-aerial fetch distance as a function of the local orientation of the coastline (Bauer et al. 2009). For parts of the Dutch and Danish coastline that are aligned SW-NE, for example, a shift to more north-westerly storm winds may therefore result in comparatively shorter fetch distances and less opportunity for

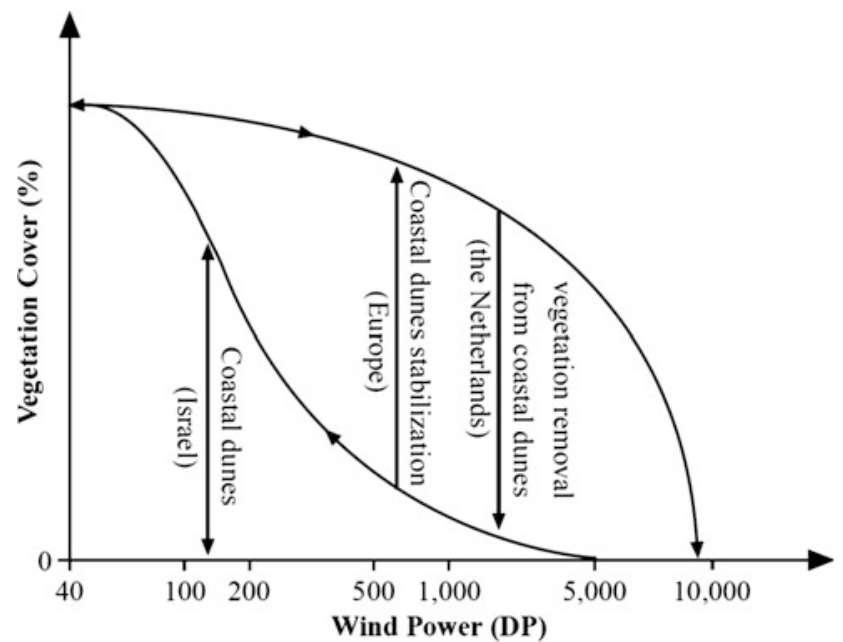

Fig. 9.3 Hysteresis in the relationship between wind power (quantified as a Drift Potential) and the vegetation cover in a coastal dune field (Tsoar 2005)

aeolian sand transport into the foredunes, as the north-westerly winds will be blowing more perpendicular to the coast. The contemporary geomorphology of the secondary dunes, meanwhile, is aligned to the typical south-westerly winds of the past and the projected shift in wind direction is likely to make it harder for aeolian activity to reactivate dormant blow-outs and parabolic dunes, as it will be acting perpendicular to their main axes and facing greater topographic roughness. Finally, even though there may be an increase in 'drift potential' (the wind power available for aeolian sand transport), its relationship with vegetation cover and associated reactivation of dormant sand dunes shows a distinct hysteresis (Tsoar 2005; Yizhaq et al. 2007), as illustrated in Fig. 9.3. While the future wind climate conditions may become equivalent to those of bare and actively migrating coastal dunes in present-day Israel, for example (as reported in the studies cited here), most North Sea Basin coastal dune fields are situated on the firmly stabilised limb of the hysteresis curve and a reactivation toward active dunes is likely to require more than just an increase in wind power. Recent attempts in the Netherlands to reactivate blowouts and parabolic dunes by removing existing vegetation have so far met with mixed success, with many opened-up sand areas quickly being recolonised and overgrown with vigorous vegetation within a few years (Arens et al. 2013), accelerated by atmospheric nitrogen deposition (Jones et al. 2004). The future change in wind climate may mean that such reactivation attempts become more successful. If not, remobilisation must be assisted by direct management intervention (Arens and Geelen 2006; Jones et al. 2010). 


\subsection{Ecology of Sandy Shores and Dunes}

\author{
Laurence Jones
}

\subsubsection{Climate Change and Dune Ecology}

European dune systems have shown constant change over time, with human influences predominating over the last few centuries (Provoost et al. 2011). However, climate change will become an increasingly important influence on dune ecosystems. Climate change is likely to affect coastal dunes in several ways. There will be direct loss of habitat due to accelerated SLR and coastal erosion (see Sect. 9.2), and changes in the climate envelopes affecting the distribution of plant and animal species. There will also be indirect effects through changes in underlying ecosystem processes. These include effects on competition, mediated via plant growth, but also effects on soil development, and groundwater systems which influence the dune wetland communities. This double impact through habitat loss as well as altered climate means that coastal habitats are more sensitive to climate change than the majority of other terrestrial ecosystems. Management of dunes, for example by livestock grazing, may interact with the effects of climate change on the vegetation, but is not discussed here.

\subsubsection{Effects of Climate Change on Dry Dune Habitats}

General effects of climate change include a lengthening of the growing season, leading to more plant growth where rainfall is not limiting. This is likely to benefit faster growing graminoids and nitrophilous species, and lead to declines in rare species. However, in the drier parts of the North Sea coast such as the Netherlands, increased summer drought may actually reduce the effective growing season, potentially reducing the dominance of some species and allowing other species to flourish. Based on the relationship between drought stress and plant compositional change in Dutch dry dunes (Fig. 9.4), Bartholomeus et al. (2012) suggested that projected increases in the severity of drought may lead to a $15 \%$ increase in the fraction of xerophytes, with potential feedbacks on dune recharge due to reduced evapotranspirative losses (Witte et al. 2012). Levine et al. (2008) predicted an increase in rare dune annuals and Witte et al. (2012) suggested a shift to more xerophytic mosses and lichens and increased cover of bare sand as a consequence of increasing summer drought, with the possible invasion of xeric Ericaceous and broom Cytisus species from more southerly European countries. Severe drought has been shown to

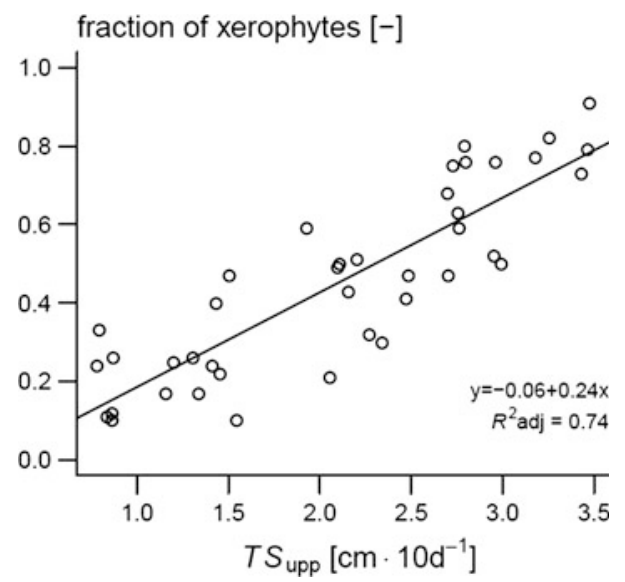

Fig. 9.4 Fraction of xerophytes as a function of the drought stress index $\mathrm{TS}_{\text {upp }}$ (uppermost transpiration stress) (after Bartholomeus et al. 2012)

negatively affect net primary production (NPP) on a European scale (Ciais et al. 2005), and such droughts are predicted to become more frequent.

The final effects of climate change that may directly impact upon the vegetation that covers most parts of the coastal dune system are changes in temperature and precipitation, and it is here that the great variety of potential climate effects may have a mixture of conflicting positive and negative biological impacts. The Holocene stratigraphic record suggests that warmer and slightly wetter climates in the past have usually resulted in dune stabilisation and full vegetation cover, whereas colder periods with less precipitation, such as the well-documented Little Ice Age, have been associated with more active dune mobility and aeolian sand transport (Pye 2001). The major dune-forming grasses, such as marram grass and sand couch Elytrigia juncea, may generally grow better in a $\mathrm{CO}_{2}$-enriched environment, and may also benefit from the projected 10-15\% increase in precipitation forecast for north-western Europe (Carter 1991). This precipitation is expected to arrive in more extreme and variable events, however, and the potentially drier summers with higher temperatures and greater heatwave risks may also result in greater wildfire incidence in the grasslands covering much of the coastal dune fields, exposing soil to wind erosion and enabling potential dune reactivation. Changes in seasonal temperature and rainfall patterns may also induce changes in species composition. Greater winter precipitation appears to facilitate scrub proliferation and overgrowth, such as sea-buckthorn, while summer droughts have an adverse impact on species diversity in dune slacks through lowering of the water table (Doody 2013). For vegetation on the back beach and foredune toe, meanwhile, simulation studies suggest that accelerated SLR and the narrowing of the beach may constrain plants to such a narrow area that successional processes 
break down (Feagin et al. 2005). Many of these effects may be difficult to distinguish from more direct anthropogenic impacts, such as grazing, nitrification, groundwater extraction, and changes in land management.

\subsubsection{Effects of Climate Change on Wet Dune Habitats}

Dune wetlands (slacks) are low-lying depressions between dune ridges, usually in seasonal contact with the water table. They are a highly biodiverse habitat, containing many rare species including plants, invertebrates, and vertebrates (Jones et al. 2011). In addition to the direct influence of temperature, rainfall and length of growing season on plant growth, dune wetlands are highly sensitive to changes in hydrological regime. They are often nitrogen $(\mathrm{N})$ and phosphorus $(\mathrm{P})$ co-limited and dune slack vegetation is dependent on hydrological regime (groundwater level, and seasonal and interannual fluctuations) and groundwater chemistry, particularly buffering capacity (Grootjans et al. 2004). The majority of dune slack plant species of high conservation value are dependent on early successional dune slacks with a high buffering capacity and low nutrient status, and which disappear as slacks decalcify or accumulate nutrients.

\subsubsection{Groundwater Level}

Both accelerated SLR and coastal erosion will lead to a change in dune groundwater tables due to impacts on the hydraulic gradient, with water tables rising (SLR), or falling (steepening of the hydraulic gradient due to coastal erosion). In Denmark it is suggested that slacks which are currently dry will become wetter due to accelerated SLR (Vestergaard 1997). However, some studies suggest that changes in recharge due to altered spatial and seasonal patterns of rainfall and evapotranspiration will have greater effects on groundwater levels than SLR or coastal erosion (Clarke and Sanitwong Na Ayutthaya 2010). In north-west England, dune water tables are predicted to fall over the next 50 years due to negative climate effects on recharge (Clarke and Sanitwong Na Ayutthaya 2010), and this is likely to apply to the majority of English dunes on the North Sea coast. In the Netherlands, recharge is predicted to change relatively little, with either slight decreases or alternatively moderate increases if feedbacks of reduced vegetation cover on the water balance are taken into account (Witte et al. 2012). A modelling study in Belgium assumed there would be increases in recharge to dune groundwater, driven primarily by increased winter precipitation (Vandenbohede et al. 2008). There is as yet little consensus on the likely effects of climate change on dune aquifer recharge and therefore a need for further work on this topic. There have also been very few studies on the impacts of changing water tables on the flora and fauna of dune wetlands. Van Dobben and Slim (2012) using a study of land subsidence due to gas extraction on the barrier island of Ameland in the Netherlands as an analogue for accelerated SLR, suggested that dune vegetation would move towards dune slacks (i.e. become wetter). In the UK, Curreli et al. (2013) showed that differences in mean water table level of only $20 \mathrm{~cm}$ differentiate between dune slack vegetation communities, with $40 \mathrm{~cm}$ separating the wettest and the driest communities. Based on predictions of falling groundwater levels for a west coast UK dune system (Clarke and Sanitwong Na Ayutthaya 2010), although outside the area of this assessment, Curreli et al. (2013) suggested that climate change may alter what are currently wet slack communities to dry slack or even dry dune grassland by the 2080s (Fig. 9.5). Changes in water table levels are also likely to affect breeding success of the Annex II listed natterjack toad Epidalea calamita which requires slacks to dry out in summer to avoid colonisation by fish predators and competitors, but needs water levels to be maintained long enough for the tadpoles to develop into toadlets. April to July is the critical breeding time for this species.

\subsubsection{Groundwater Chemistry}

Dune groundwater composition is sensitive to atmospheric $\mathrm{N}$-deposition and nitrogen and phosphorus inputs from other sources. In dune groundwater, it has been suggested that above total inorganic nitrogen concentrations of $0.2-$ $0.4 \mathrm{mg} \mathrm{TIN}^{-1}$ there may be adverse impacts on dune slack species and soils (Davy et al. 2010), although this threshold has not been tested empirically in dunes.

Although there is relatively little research into the effects of climate change on dune groundwater chemistry, it could be expected to change in the following ways. Rates of mineralisation of soil organic matter are likely to increase due to higher temperatures (Emmett et al. 2004) and an extended growing season (Linderholm 2006) in the majority of North Sea coastal areas, particularly in the north. This will lead to increased production of both nitrates $\left(\mathrm{NO}_{3}\right)$ and dissolved organic nitrogen (DON), inevitably increasing $\mathrm{N}$-leaching fluxes to the groundwater. This may not occur in the southern North Sea area however, due to increased soil-moisture deficits in summer acting to reduce mineralisation. In areas with falling groundwater levels due to climate change, or where there is an influence of external groundwater or surface waters on a site, there is potential for nutrient concentrations entering the site to be higher if these source waters become concentrated due to higher evapotranspiration rates and subsequent reduced runoff and lower river flows. Such a mechanism is suggested for altered water composition of the River Meuse under climate change (Van Vliet and Zwolsman 2008). The opposite may occur in the north of the region where runoff is expected to increase (DiPOL 2012). 
Fig. 9.5 Projections of April groundwater level to the 2080s for a UK site under UKCIP02 medium-high emissions scenario (SRES A2) (Hulme et al. 2002), showing the 70 and $90 \%$ confidence intervals $(\mathrm{CI})$, and corresponding frequency distributions for dune slack communities based on those water levels (after Curreli et al. 2013)

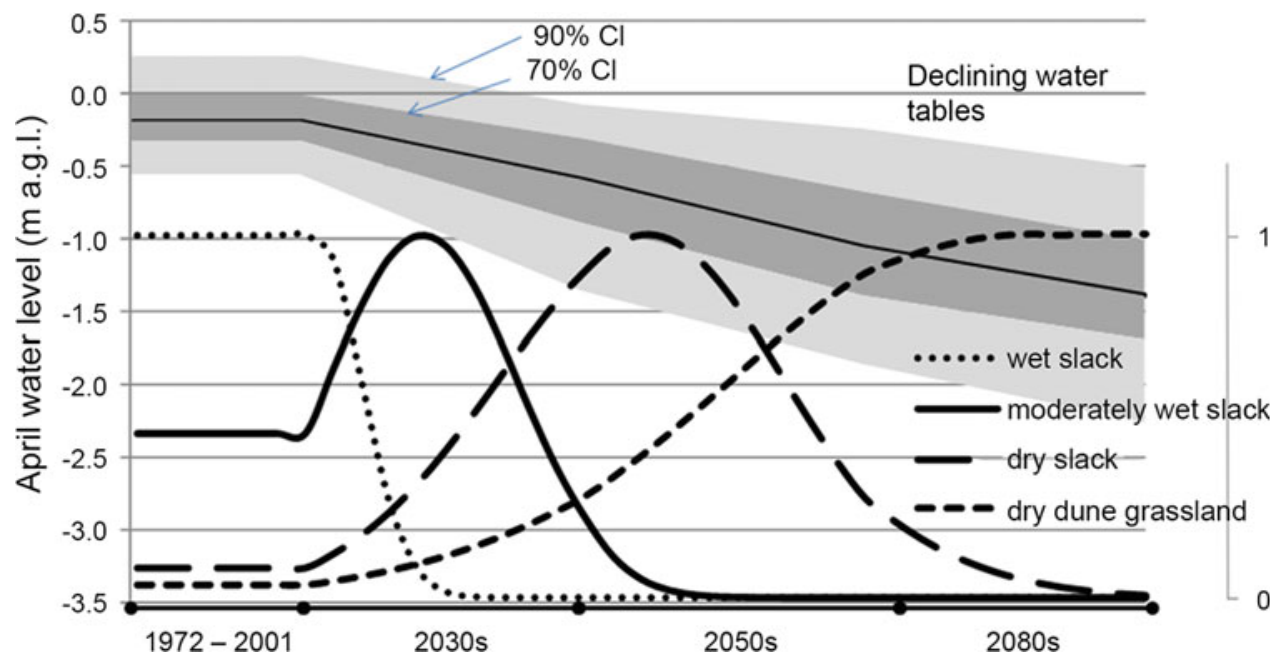

\subsubsection{Interactions with Hydrological Management}

Hydrological management both on- and off-site can affect water composition. A lowering of the water table due to drainage, water abstraction or other causes such as high evapotranspiration from forest, may allow groundwater influx from other sources such as streams or drainage ditches bordering the site or groundwater from inland. The danger is greatest in late summer when dune groundwater tables are at their lowest. These other hydrological inputs to the groundwater may contain high levels of nutrients or other chemicals which affect water composition, particularly if they drain agricultural land. Alterations to the management of hydrological regimes in response to climate change therefore also have the potential to impact dune groundwater chemistry.

\subsubsection{Climate Change Effects on Individual Species}

Climate change is likely to affect the distributions of individual dune plant species, although there have been relatively few studies on this topic. In Denmark, a study looking at spatial analogues of predicted climate in 2100 suggests that coastal heaths and sand dune vegetation are likely to be vulnerable, particularly the communities "decalcified fixed dunes with Empetrum nigrum" (type 2140 according to Annex I of the Habitats Directive; European Commission 1992) and "fixed coastal dunes with herbaceous vegetation" ('grey dunes', type 2130) (Skov et al. 2009). The study lists 17 species which may disappear including crowberry Empetrum nigrum and sea brookweed Samolus valerandi, and 25 coastal species likely to move north into Denmark, some of which may become problem species. In the UK, the Monarch programme modelled changing climate envelopes for a wide variety of species, including some dune species. Generally species ranges shifted northwards and westwards with marsh helleborine Epipactis palustris and the natterjack toad potentially gaining climate space in the UK, while the variegated horsetail Equisetum variegatum which has a predominantly northern distribution in the UK would lose climate space (Harrison et al. 2001). Note these are predicted changes in climatic envelopes, and do not take into account the subtleties of changing recharge which might affect dune groundwater levels in a different way (see Sect. 9.3.3.3). The more recent BRANCH project modelled changing climate space of 386 plant and animal species, and predicted that the fen orchid Liparis loeselii was likely to lose more than $90 \%$ of its climate space by 2080 (Berry et al. 2007). Metzing (2010) modelled the northward shift of the dune grass Leymus arenarius in Europe, which would completely disappear from current parts of its range in the southern North Sea areas of Germany, the Netherlands, Denmark and England under the worst-case scenario by 2050 (Fig. 9.6).

\subsubsection{Other Climate Change Impacts}

\subsubsection{Invasive Species}

There is much evidence in aquatic systems that invasive species may be favoured by climate change. In terrestrial systems, there is far less evidence for this. However, certain plant species such as bird cherry Prunus serotina in the Netherlands and Belgium (Baeyens and Martínez 2004) and Japanese rose Rosa rugosa in Germany (Isermann 2008) have become highly invasive in dune systems, despite being present on the systems for many decades. It is unclear why their extent has suddenly increased, but changes in climate (warmer winters and fewer severe frosts are one suggestion), while the combination of changing climate and elevated nutrient levels in dune soils due to $\mathrm{N}$-deposition may be a contributory factor. Although invasive species may initially enhance species richness, once tall species become dominant they can outcompete low-statured species, and decrease species richness. 
Fig. 9.6 Distribution of the dune grass Leymus arenarius in Europe showing: a. current distribution, b. modelled distribution under recent climate, c. distribution under 2050 a best-case climate warming of $1.5^{\circ} \mathrm{C}$ and d. distribution under a worst-case climate warming of $2.5^{\circ} \mathrm{C}$ (Metzing 2010) (a)

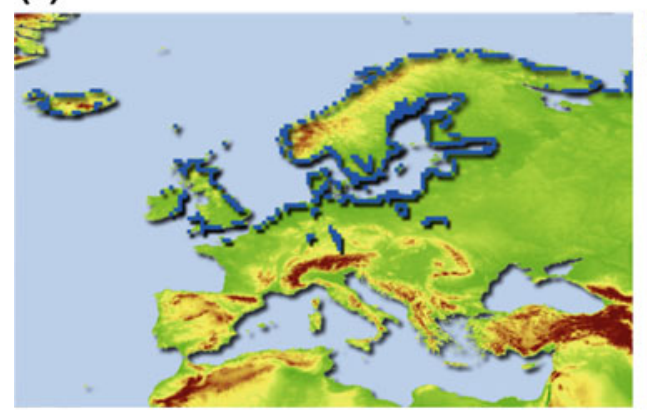

(b)

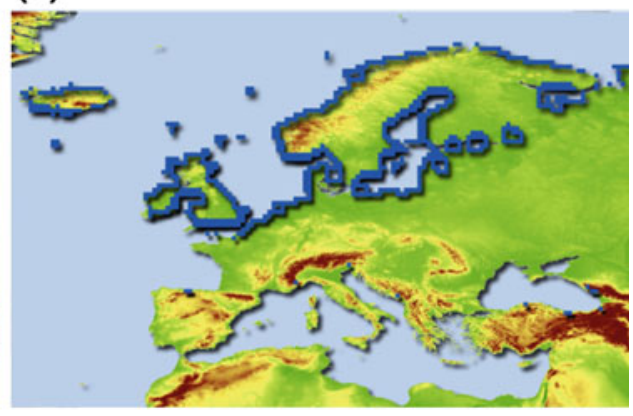

(c)



(d)

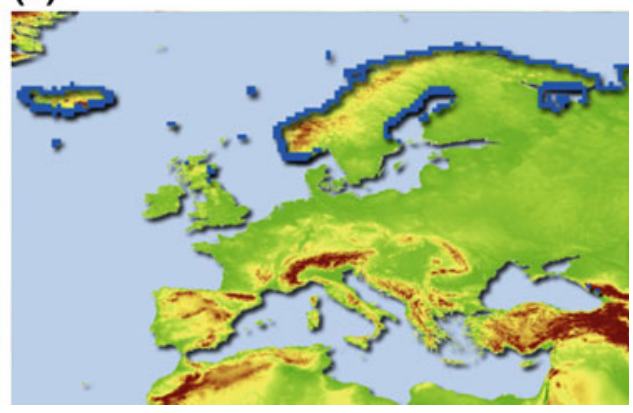

\subsubsection{Impacts on Soils}

Where higher temperatures cause greater plant growth, the increased plant production will stimulate soil development through greater litter inputs. Rates of soil organic matter accumulation represent a balance between plant productivity and rates of organic matter decomposition. While the net balance is unknown for many habitats, a dune chronosequence study over the last 60 years linked faster rates of soil development to periods of higher temperatures, and to periods with lower rainfall (Fig. 9.7) (Jones et al. 2008); changes were also correlated with increasing $\mathrm{N}$-deposition. Other changes in soils may include decalcification rates. The rate of leaching of carbonates from dune soils is largely a function of rainfall, therefore changes in rainfall are likely to lead to increases or decreases in decalcification rates of dune soils.

\subsubsection{Atmospheric Nitrogen Deposition and Interactions with Climate Change}

Atmospheric deposition remains a significant source of nitrogen input in many countries around the North Sea, particularly the Netherlands and Denmark. Recent trends in $\mathrm{N}$-deposition in Europe have shown some decline in $\mathrm{NO}_{\mathrm{X}}$ emissions and are forecast to decrease further for oxidised nitrogen, but only slightly for reduced nitrogen (Winiwarter et al. 2011). Climate is a strong determining factor in the balance of wet and dry $\mathrm{N}$-deposition, and involves complex interacting processes. Relatively little is known about how climate change may affect $\mathrm{N}$-deposition but is not expected to alter deposition of oxidised nitrogen much (Langner et al. 2005), and it is generally assumed that changes in emissions will have a greater impact on atmospheric deposition than any climate-related effect (Mayerhofer et al. 2002).

Along gradients in atmospheric deposition, studies have shown increased plant production and a decrease in species richness in dunes with higher atmospheric deposition (Fig. 9.8) (Jones et al. 2004; Hall et al. 2011). An increase in biomass occurs above critical levels of $10-20 \mathrm{~kg} \mathrm{~N} \mathrm{ha}^{-1}$ year $^{-1}$ in dry dune communities (EUNIS types B1.3, B1.4, B1.5) and above $10-25 \mathrm{~kg} \mathrm{~N} \mathrm{ha}^{-1}$ year $^{-1}$ in dune slack

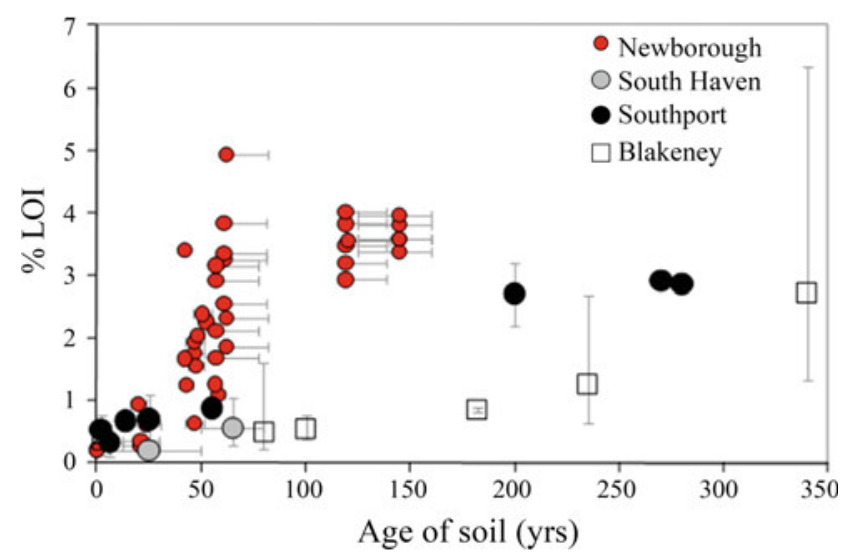

Fig. 9.7 Changes in soil organic matter accumulation in a recent dune soil chronosequence in the UK (Newborough), compared with older UK published chronosequence studies (South Haven 1960; Southport 1925; Blakeney 1922), after Jones et al. (2008) 
Fig. 9.8 Change in species richness of de-calcified dunes in north-western Europe along a gradient of atmospheric nitrogen (N) deposition (after Hall et al. 2011)

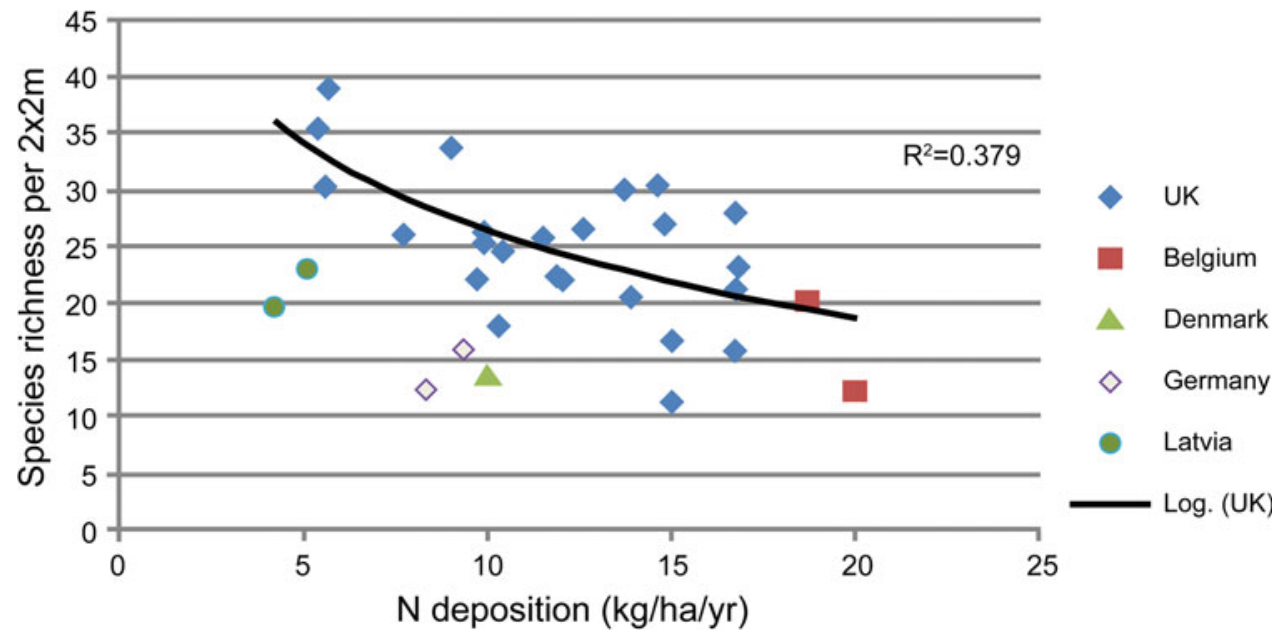

communities (EUNIS type B1.8) (Bobbink et al. 2010). The atmospheric deposition of nitrogen in combination with the release of phosphorous from enhanced mineralisation may result in increased plant production and further spread of grasses (Kooijman et al. 2012).

There is little direct or indirect evidence from dunes of interactions between climate change and N-deposition, although studies in other ecosystems suggest that the combination of higher temperatures and increased rainfall, which are both projected to occur in the northern North Sea dune systems, will lead to faster mineralisation of soil organic matter (Rustad et al. 2001), and therefore faster N-cycling. This may remobilise stored nitrogen in soils and increase leaching of dissolved organic nitrogen (DON) into dune groundwater. There are indications that higher DON concentrations in dune groundwater, which thereby increase the negative impacts of $\mathrm{N}$-deposition are correlated with higher $\mathrm{N}$-deposition (Jones et al. 2002), suggesting that impacts could be worse in areas of high nitrogen inputs. However, in the southern North Sea area where summer soil moisture deficits act to reduce mineralisation rates, there may be less $\mathrm{N}$-leaching into groundwater as a result.

\subsection{Fine-Grained Sediment Transport and Deposition in Back-Barrier Areas}

Jesper Bartholdy

\subsubsection{Physical Conditions}

As a shallow semi-enclosed shelf sea, the North Sea imports fine-grained sediment (silt, clay, organic material) from the adjacent North Atlantic. The net import across the transect between Scotland and Norway each year is estimated at 7 million tons and through the Channel at about 14 million tons (Pohlmann and Puls 1993). Due to the generally anti-clockwise circulation in the North Sea, the sediment contribution from the Channel is carried northward where it mixes with sediment of terrestrial origin carried into the North Sea from rivers draining north-western Europe. Part of this flux of fine-grained sediment passes the German Bight close to land and then continues northward as part of the Jutland Current. During this passage, the tidal exchange between the North Sea and the extensive barrier system of the Wadden Sea induces a net landward transport of sediment into the sheltered tidal areas behind the barrier islands.

This import is due to lag effects first described by Postma (1954, 1961, 1967) and Van Straaten and Kuenen (1957, 1958). At high tide, the shift between flood and ebb is slower and involves larger excursions of the water, than the shift between ebb and flood at low tide. Together with the fact that it takes time for a suspended particle to settle out during slack water (settling lag) and that erosion/resuspension of a settled fine-grained particle-due to adhesion-demands stronger currents than those in which the particle settled out (scour lag), this asymmetry causes a landward shift of sediment for each tidal period. The effect is enhanced by the apparent paradox that the average water depth in a tidal area is smallest during high tide and largest during low tide. A randomly located suspended particle in the exchanged water mass is therefore less prone to settle out during low tide, when only the relatively deep channels are inundated than it is during high tide, where the whole tidal area is inundated with a relatively small mean water depth. A quantitative model of the involved processes during settling and resuspension of sediment particles in tidal currents have shown that scour lag is by far the most important mechanism concerning import of fine-grained sediment into the Wadden Sea (Bartholdy 2000). Calibrated on the basis of 
(a)
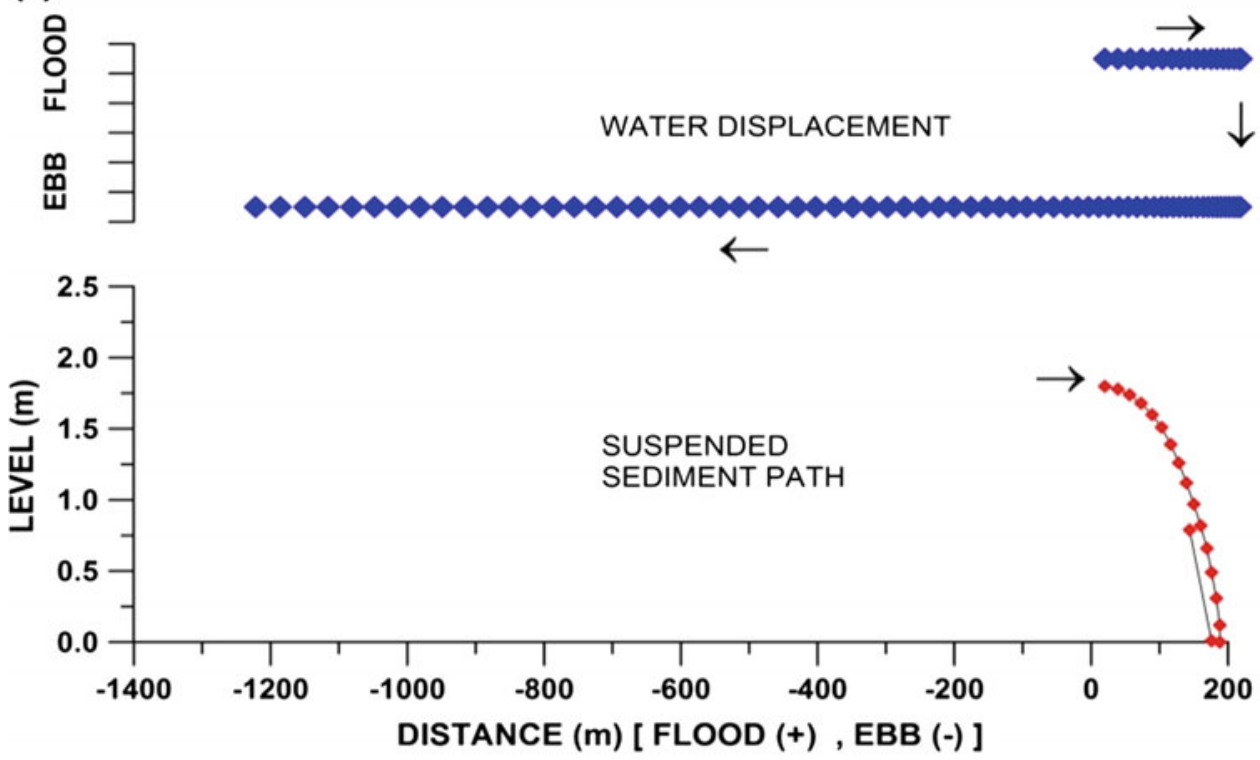

(b)



Fig. 9.9 Principals of the import of fine-grained material to tidal areas due to settling lag and scour lag. a The location of a water parcel (blue) and sediment particle (red) is tracked at time intervals of $100 \mathrm{~s}$ over a high tide period in the inner part of a tidal area. The tracking takes place from the time the particle starts to settle (at $0 \mathrm{~m}$ ) to the time it is resuspended (at $-1200 \mathrm{~m}$ ). During the period when the particle settles out, it is transported a distance of $200 \mathrm{~m}$ inland (settling lag). From here it is stable on the bottom until the water parcel which delivered it has moved $1200 \mathrm{~m}$ seawards of the zero point (scour lag). First when the

the dynamic conditions in the tidal area Grådyb in the Danish Wadden Sea, the model showed a typical net landward migration on the order of $1 \mathrm{~km}$ for each tide due to lag effects (Fig. 9.9).

As a consequence of the lag effects, fine-grained sediments concentrate and form mud flats in inner parts of the original water parcel has moved to here, current velocity at the location of the settled particle is large enough to resuspend it. Thus, the combined effect of settling lag and scour lag is a shift of the sediment particle to be suspended in a new water parcel located $(200+1200 \mathrm{~m})$ $1400 \mathrm{~m}$ inland. b The same dynamics over the low water period in the tidal inlet. Here the settling lag is about $120 \mathrm{~m}$ and the scour lag about $400 \mathrm{~m}$. Combined, the seaward shift is therefore $(120+400 \mathrm{~m}) 520 \mathrm{~m}$. The joint shift over both flood and ebb is thus (1400-520 m) $880 \mathrm{~m}$ in an inland direction (after Bartholdy 2000)

Wadden Sea. During storms where wind tide increases the water level and waves resuspend fine-grained sediments from these mud deposits, adjacent salt-marsh areas get inundated by turbid water and sedimentation of fine-grained sediment takes place on the marsh surface during high tide slack water. Because of the sheltering salt-marsh plants, resuspension of 


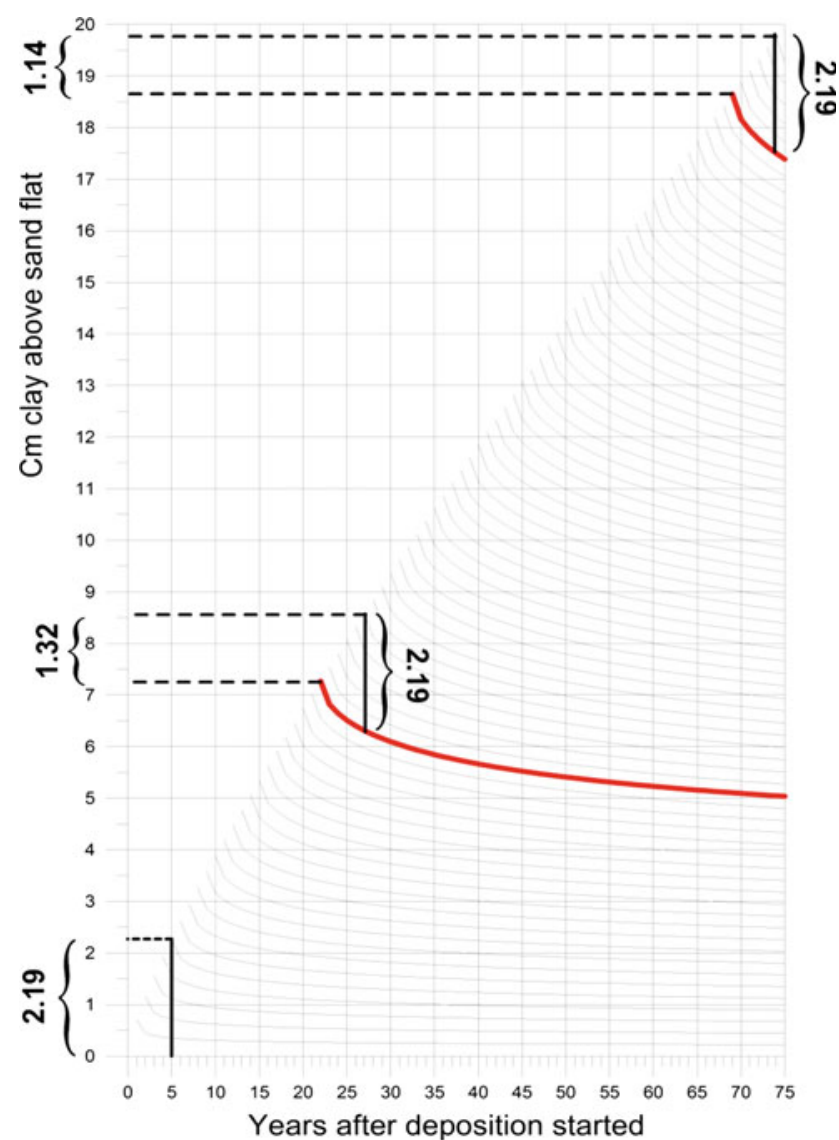

Fig. 9.10 Autocompaction in a salt marsh deposition on top of an incompressible sand flat. The accumulation rate is a constant $1.7 \mathrm{~kg}$ $\mathrm{m}^{-2}$ year $^{-1}$. The semi-horizontal lines represent yearly locations of former salt-marsh surfaces in the sediment column. The left-hand end of these lines represents the salt-marsh surface location above the sand flat at the year of deposition. After five years of deposition, the salt-marsh thickness above the sand flat is $2.19 \mathrm{~cm}$. The two red lines represent years where the salt marsh was marked by a tracer. As it appears five years of deposition also add $2.19 \mathrm{~cm}$ on top of the marker horizon; but because of compaction the absolute level increase of the salt-marsh surface, 70 years after deposition, is only about half of this amount, $1.14 \mathrm{~cm}$ (after Bartholdy et al. 2010a)

the settled particles is impeded in the succeeding ebb current, and salt marsh therefore forms the end destination of silt, clay and organic material introduced into the Wadden Sea from the North Sea and local sources. The contribution from the North Sea is by far the largest concerning the net deposition. A combined sediment budget based on results from Pejrup et al. (1997) and Pedersen and Bartholdy (2006) for the four northernmost tidal areas in the Wadden Sea (Lister Tief, Juvre Dyb, Knude Dyb and Grådyb) covering an area of $855 \mathrm{~km}^{2}$ including salt marshes, shows an accumulation of fine-grained material of 230,000 t year ${ }^{-1}$ of which $64 \%$ is derived from the North Sea, $14 \%$ from primary production, $12 \%$ from local rivers, $9 \%$ from coastal erosion and $1 \%$ from atmospheric deposition.
Once deposited on the salt-marsh surface, the fine-grained sediment consolidates due to autocompaction (e.g. Cahoon et al. 1995, 2000). This process causes the bulk dry density to vary from the top layer downwards as a logarithmic increasing function (Bartholdy et al. 2010a). Because of this, it can be misleading to measure salt-marsh accumulation by means of level/thickness change alone. Bartholdy et al. (2010a) showed that on the Skallingen back-barrier marsh in the Danish Wadden Sea, a constant accumulation (weight/area/time) can give half of its initial value of accretion (thickness change/time) after about 70 years of sedimentation (Fig. 9.10).

Sand is also found in salt marshes. Most of it is mobilised from adjacent sandy tidal flats and deposited on the salt marsh during storms. Not many direct measurements have been carried out on the effects of a storm surge on sediment transport. On 3-4 December 1999 during a storm surge at the back-barrier marsh of Skallingen, the suspended sediment concentration (SSC) on the intertidal flats increased from 10 to $200 \mathrm{mg} \mathrm{l}^{-1}$, and the mobile layer of the intertidal flat was removed. The estimated sediment deposition on the salt marsh was $0.15 \mathrm{~mm}$. This is only about $50 \%$ higher than that of a previously monitored storm, and corresponds to $<10 \%$ of the annual deposition at the site (Bartholdy and Aagaard 2001). These authors concluded that the effects of storms on deposition depend on the season as well as the sequence of previous import and high-energy events. One extreme periodic storm can be of less importance for annual variations in salt-marsh deposition than more frequent minor surges (Bartholdy and Aagaard 2001; Bartholdy et al. 2004). During deep storms, flooding wave energy may be too strong to be affected by the local vegetation structure and hence prevent settlement of sediment, or may even cause erosion (Silva et al. 2009). Apart from the quantity of material deposited during storm surges, its composition may also be affected. The occurrence of storms can be reflected in the grain-size distribution of the deposited sediment (Allen 2000). The occurrence of dated thin sand layers at the back-barrier marsh of Schiermonnikoog (Netherlands), suggests that storms capable of depositing sand in the marsh occur about every decade (De Groot et al. 2011). Storm-related coarse-grained layers and sand deposits may occur at various locations within a salt marsh. At the back-barrier marsh of Schiermonnikoog, sand layers occur on $20 \%$ of the marsh area and are partly associated with the local sources of the sand (i.e. marsh creeks, the salt-marsh edge and washovers). In total, sand layers contribute less than $10 \%$ of the volume of marsh deposits on Schiermonnikoog (De Groot et al. 2011). The back-barrier marsh of Skallingen contains about $15 \%$ sand (Bartholdy 1997). Deposition of sand layers after storm surges has also been reported from intertidal flats and salt marshes in the Leybucht on the mainland coast of Germany (Reineck 1980). 


\subsubsection{Effects of Climate Change}

\subsubsection{Sea-Level Rise}

Studies on the development of salt marshes in relation to climate change almost exclusively deal with their ability to survive different SLR scenarios. As a rule, the critical level for salt-marsh survival is taken to be close to the mean high tide (MHT) level, usually considered as the level describing the border between the pioneer zone and the lower marsh (see Fig. 9.16 in Sect. 9.6). Assessments of salt-marsh survival are normally based on accretion models built on the basis of the continuity equation for salt-marsh sedimentation (e.g. Allen 1990). French (1993) added different types of semi-empirical equations of deposition, usually based on either a constant characteristic concentration of suspended sediment in the flooding water or concentrations positively correlated with the MHT level (e.g. Temmerman et al. 2003; Bartholdy et al. 2004). The organic component of salt marshes in the Wadden Sea is usually 10-20\%, of which the major part is deposited together with the mineral part of the sediment. An additional source of organic material, the so-called belowground production, is small and either incorporated in the model calibration or added as a constant value.

French (1993) estimated the organic contribution to accretion for a British salt marsh to be about $0.2 \mathrm{~mm}_{\text {year }}{ }^{-1}$. Running this type of model for the Skallingen back-barrier marsh, sedimentation was shown to correlate with the North Atlantic Oscillation (NAO) winter index which explained about $63 \%$ of the variation in the period 1970-1999 (Bartholdy et al. 2004). Using an improved version of the model, Bartholdy et al. (2010b) modelled the distribution of salt-marsh sedimentation on the Skallingen back-barrier marsh (Fig. 9.11) and analysed its vulnerability to different SLR scenarios. This type of assessment is either based on a balance between SLR and salt-marsh accretion or on identifying the SLR during which the salt marsh will survive a certain number of years. The latter approach is most common, as the time it takes to reach a genuine balance can be unrealistically long for a constant SLR scenario (e.g. Fig. 9.12). It was found for the Skallingen salt marsh that for the next 100 years, the salt marsh could survive a SLR of about $4 \mathrm{~mm}$ year $^{-1}$ while a SLR of $6 \mathrm{~mm}$ year ${ }^{-1}$ would drown the inner part, and the outer part-the salt-marsh edge-would just survive. For a salt marsh further south on the German island of Sylt, Schuerch et al. (2013) found a similar although considerable larger mean SLR of close to $20 \mathrm{~mm}$ year ${ }^{-1}$. Both values are considered realistic for Wadden Sea salt marshes.

Predictions of this type depend primarily on the amount of sediment available in the close vicinity of the salt marsh, and this can vary considerably from place to place. This parameter can also vary in time, and represents the most obvious source of error in such assessments. As all models
Fig. 9.11 Distribution of the typical deposition of suspended sediment in flooding water over the Skallingen back-barrier marsh at a high water level of $1.3 \mathrm{~m}$ Danish Normal Nul DNN (with about $0.5 \mathrm{~m}$ of water inundating the salt marsh). This level is the most effective high water level in terms of both frequency and concentration in relation to salt-marsh deposition. The map is superimposed on an aerial photo visible outside the modelled area and in the salt-marsh creeks (after Bartholdy et al. 2010b)

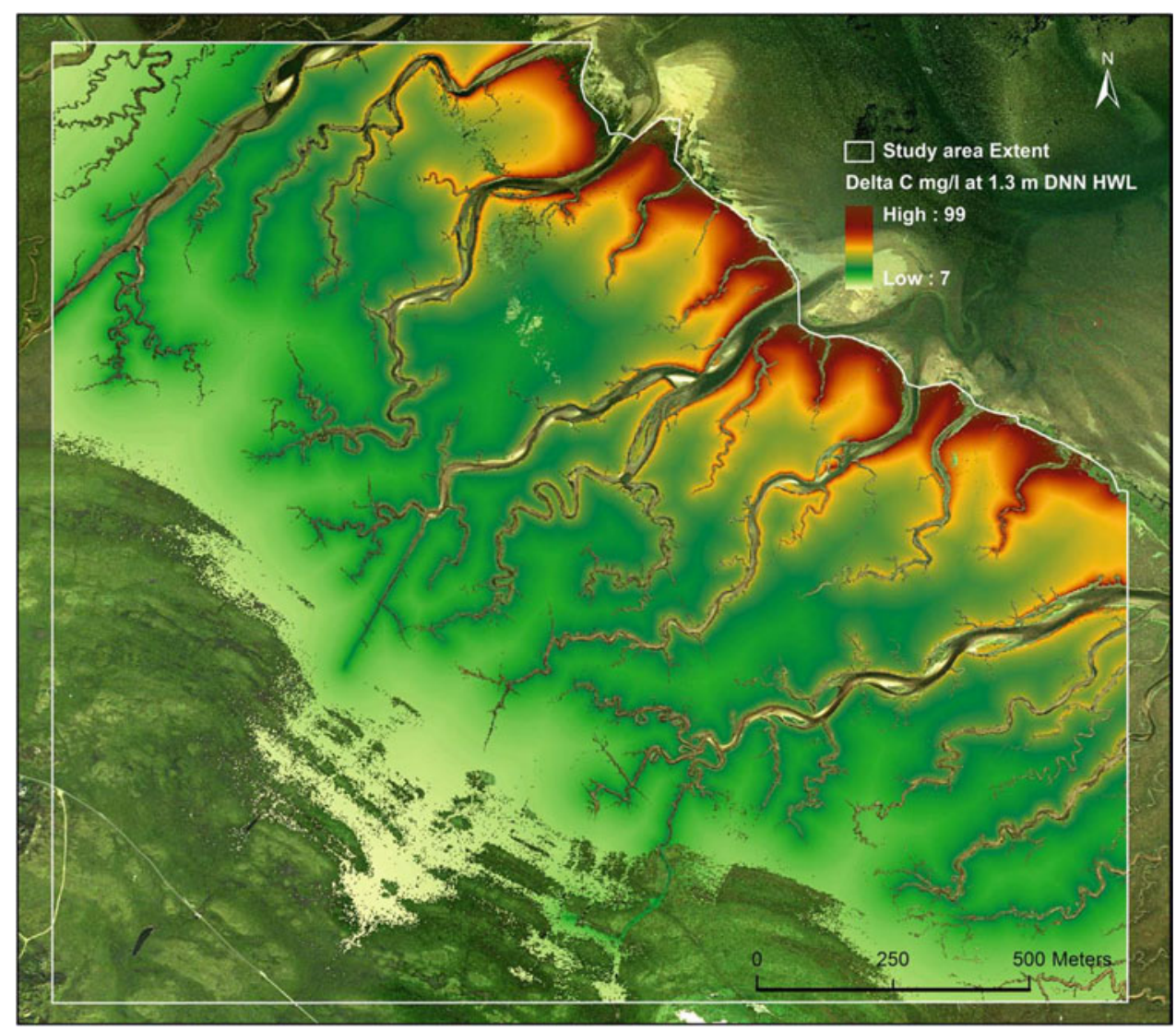




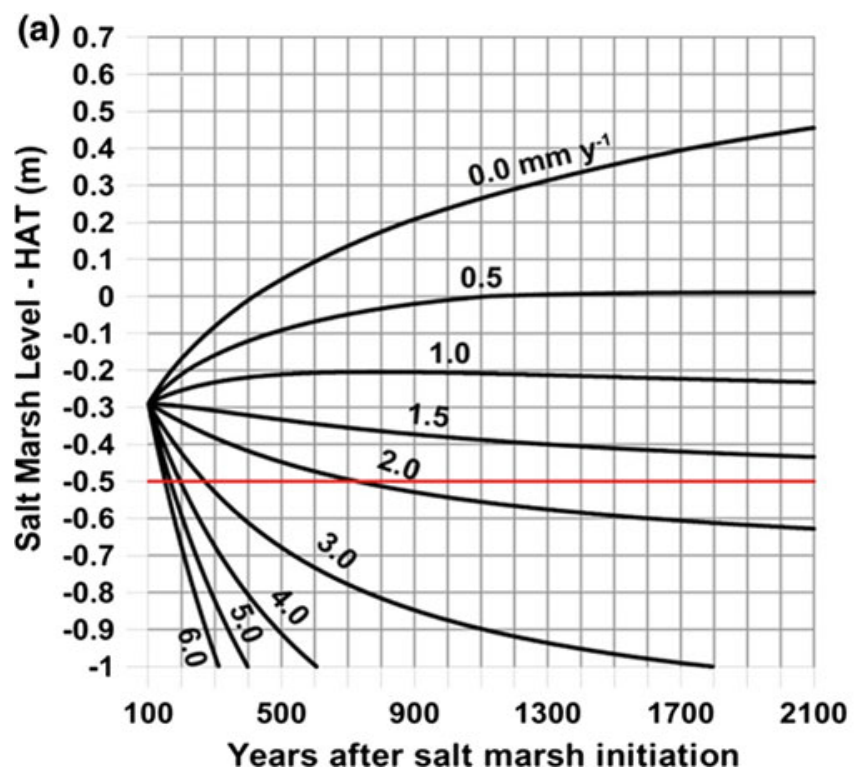

Fig. 9.12 Modelled salt-marsh level at the Skallingen back-barrier marsh minus the highest astronomical high tide level (HAT) for different sea-level rise (SLR) scenarios. A difference between the two of $-0.5 \mathrm{~m}$ represents the mean high tide level, and is regarded as the lower limit for salt-marsh growth. The start time of 100 years is chosen

are based on a calibration related to actual conditions, they will not make correct predictions of salt-marsh sedimentation if the sediment supply should for whatever reason change over time. The above-mentioned results, however, do not indicate any immediate threat to Wadden Sea salt marshes in general, including back-barrier marshes and mainland marshes. Slow-growing marshes such as that on the Skallingen peninsula, may become threatened in 50 years or so if SLR accelerates to much over $5 \mathrm{~mm}_{\text {year }}{ }^{-1}$.

\subsubsection{Wind Climate}

In addition to sediment availability, sediment dynamics (and thus ultimately changes in for example, wind climate) can also play an important role in salt-marsh sedimentation. A major feature related to this is illustrated by the difference between the Wadden Sea and similar areas on the east coast of the USA. Both areas are subject to salt-marsh formation but the salt marshes are very different. In the Wadden Sea, livestock can graze on salt marshes in summer, something which is impossible in the soft mud of the salt marshes in Georgia, for example. The reason for this is the wind-tide effect which is present in the Wadden Sea and absent in Georgia. Because of this, salt marshes in the Wadden Sea quickly grow higher than the highest astronomical tide (HAT), something that never happens in Georgia (Bartholdy 2012). The dry firm summer salt-marsh areas above HAT in the Wadden Sea, therefore appear totally different from the frequently inundated, soft and unsuitable for livestock-grazing salt marshes of Georgia. The two salt-marsh types can therefore be



because the salt marsh is about 100 years old. a Conditions characteristic of the central section of the back-barrier marsh. b Conditions characteristic for the area close to the salt-marsh edge (Bartholdy et al. 2010b)

regarded as occurring at opposite ends of a continuum of salt-marsh types directly affected by climate change in terms of changes in wind climate.

\subsection{Estuaries: Geomorphology and Sediment Transport}

Stijn Temmerman

\subsubsection{General Properties}

Major estuaries around the North Sea include the Western Scheldt (Belgium and the Netherlands), Eastern Scheldt (the Netherlands), Ems-Dollard (the Netherlands and Germany), Weser (Germany), Elbe (Germany), Firth of Forth (UK), Humber (UK), and Greater Thames (UK). Although historic human modification of these estuaries is very important (see Sect. 9.5.2), their geomorphology is generally characterised by an overall funnel-shaped, landward converging form, including landforms such as subtidal channels, sub- and intertidal sandy shoals or bars, intertidal mudflats and intertidal marshes (ranging from salt, brackish to freshwater tidal marshes) (Fig. 9.13) (Seminara et al. 2001; Prandle 2004; Dronkers 2005; Van Maanen et al. 2013). In the most downstream, wider part of the estuaries the subtidal channel system often comprises multiple channels, including flood and ebb channels, which develop as a consequence of the 


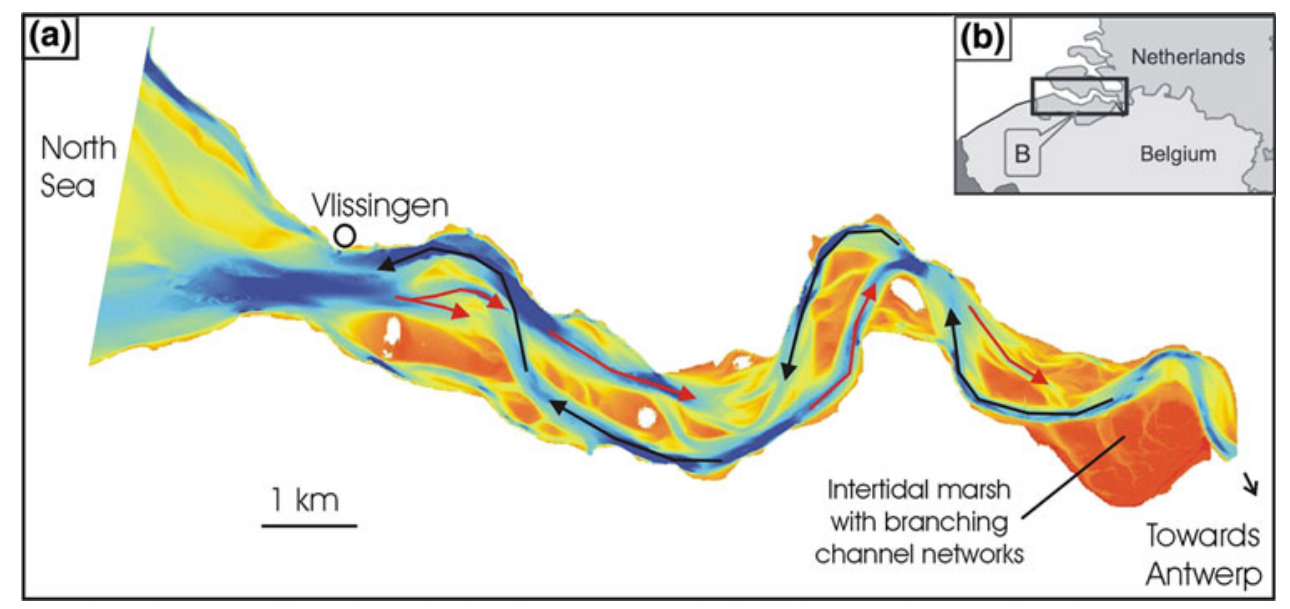

Fig. 9.13 Typical example of a North Sea estuary, the Scheldt estuary, SW Netherlands and Belgium. a General location. b Bathymetry of the most downstream section of the estuary (up to the Dutch-Belgian border). Red areas indicate intertidal flats and marshes; yellow and blue areas indicate subtidal areas; darker blue indicates deeper areas. Flood and ebb channels are indicated with red and black arrows, respectively.

semi-diurnal alternating flood and ebb flow directions and inertia in the water movement (Fig. 9.13). More upstream, estuarine channel width and depth decrease and the multiple channel system generally converges towards a single channel system. Branching channel networks typically develop where extensive intertidal flats and marshes are tidally flooded and drained (Fig. 9.13). The most downstream section may transition into a back-barrier tidal lagoon system such as in the Wadden Sea area (e.g. Ems-Dollard, Weser, Elbe) with back-barrier marshes.

The coarse-grained bedload transport is most intense in the subtidal channels and therefore is most determining for the morphodynamic evolution of these channels, while the suspended sediment is more important for the evolution of the intertidal mudflats and marshes. As a consequence of (1) the tidal pumping of sediments, (2) estuarine circulation due to stratification or partial mixing of salt seawater and fresh river water, and (3) settling and scour lag effects as described for the Wadden Sea (see also Sect. 9.4), the more downstream part of estuaries is generally dominated by a net landward transport of sediments of a marine origin; while in the most upstream part of estuaries there is an input of terrestrial sediments through rivers that discharge into the estuary. As a consequence of these converging sediment transport directions, and in combination with flocculation processes, the SSC typically reaches a maximum in the so-called estuarine turbidity maximum (ETM) zone (Fig. 9.14) (e.g. Dyer 1997). The existence of an ETM is well-documented for most estuaries in the North Sea region (e.g. Uncles et al. 2002), and may have important implications for the estuarine ecosystem, because turbidity controls
Note as for almost all estuaries around the North Sea, human modification of the estuary is important mainly due to large historical embankments of intertidal areas (around 100,000 ha over the last 1000 years) and channel dredging (deepening of sills between the North Sea and port of Antwerp)



Fig. 9.14 Time-averaged longitudinal variation in suspended sediment concentration (SSC) along the Scheldt estuary, calculated from monthly monitoring data for 1996-2001, showing the presence of an Estuarine Turbidity Maximum (ETM) zone at around $100 \mathrm{~km}$ from the estuary mouth in the North Sea. Error bars represent the 10th and 90th percentiles of all SSC measurements at a station (after Temmerman et al. 2004)

the depth of light penetration into the water column and thereby the potential limitation of primary production by phytoplankton if turbidity is too high (e.g. Cloern 1987). Furthermore, the SSC determines the capacity of intertidal mudflats and marshes to grow with SLR by sediment accretion (more details in Sect. 9.5.3.1).

The SSC may also depend on sediment surface stability depending on biological controls. These can be divided into biostabilisation and biodestabilisation, with sediment surface stability ultimately dependent on the balance between the 
two competing sets of processes. This balance varies spatially, both vertically within the tidal frame and horizontally along the estuarine salinity gradient, and temporally, on seasonal, interannual and perhaps longer timescales. These patterns have implications for estuarine morphology; strong biostabilisation will lead to a flatter profile because flood and ebb tidal pulses will be less effective on intertidal flat surfaces. Conversely, destabilisation will lead to lower critical shear stresses for erosion and thus result in steeper profiles. In general, biostabilisation is associated with microorganisms and biodestabilisation with a benthic macrofauna. Thus, for the Humber estuary (UK), Wood and Widdows (2002, 2003) developed a simple (if unvalidated) cross-shore model incorporating biostabilisation (in the form of chlorophyll $a$ content) and bioturbation (from the burrowing bivalve Baltic tellin Macoma balthica). The model suggests that the erosion or deposition driven by natural fluctuations in biota densities are as large as the changes caused by variations in tidal range and currents over a spring-neap cycle or are equivalent to a doubling of the external sediment supply. Seasonal variations in the density of stabilising diatoms can alter the magnitude of net deposition by a factor of 2 and interannual changes in Macoma balthica density change deposition by a factor of 5 . In a UK climate change scenario, milder winters result in lower springtime recruitment of Macoma, leading to lower rates of bioturbation at mid-intertidal levels and lower sediment supply to the upper intertidal zone and its fringing salt marshes (Wood and Widdows 2003).

Using the same two biotic groups, Paarlberg et al. (2005) extended Wood and Widdows (2002) approach, showing that changes in bioturbation and stabilisation by microphytobenthos can potentially alter the mud content and elevation (by $5-10 \mathrm{~cm}$ ) of shoal banks in the Western Scheldt estuary (Netherlands). In fact, field observations in the Western Scheldt estuary show that two stable sedimentological states are present at intermediate levels of bed shear stress, either a bare surface with low silt content or a high silt content supporting a high density of diatoms. This bimodal pattern results from the feedback links between the biota and silt content. Diatom growth rates are enhanced by the nutrients present in silt-rich sediments and diatom resuspension falls as diatom density increases, favouring the accumulation of silts. Loss of diatom cover sets this dynamic in reverse (Van de Koppel et al. 2001).

\subsubsection{Human Impacts}

Human impacts on estuarine geomorphology are particularly significant in the North Sea region. A general phenomenon is the historical reclamation of intertidal flats and marshes in many estuaries, since Medieval and even Roman periods. As a result the present-day area of intertidal flats and marshes is only a tiny fraction of the original area. For example, in the Western Scheldt estuary around 100,000 ha of intertidal areas - mostly marshes-have been reclaimed by seawall building since 1200; nowadays only around 2800 ha of marshes and 8000 ha of intertidal flats (i.e. $10 \%$ ) remain (Meire et al. 2005). Apart from the direct impact on the reclaimed land, the geomorphology of the remaining estuary will also react. The large reduction in intertidal areas may considerably reduce the volume of an estuary and hence its tidal prism (the volume of water within the estuary between high and low tides). Due to the reduced tidal prism and tidal currents, the long-term response of the estuary is that channels may fill with sediments and remaining intertidal mudflats in front of the seawalls may silt up promoting the succession towards marshes (e.g. Townend 2005). Extreme cases exist where progressive historical land reclamation resulted in a cascading effect and almost complete silting up and disappearance of the estuary (e.g. Zwin estuary towards Bruges, Belgium). In other cases, estuaries are still responding to historical land reclamation and estuarine sediment infilling may be expected to continue over coming decades. In still more cases, other processes may have compensated for the loss of tidal prism and land reclamation may not induce as much estuarine sediment infilling. As De Swart and Zimmerman (2009) concluded in an extensive review, interactions between intertidal and channel morphodynamics are complex and still not fully understood.

More recent human impacts include the dredging and canalisation of estuarine channels, because many estuaries in the North Sea region provide access to major harbours, including the ports of Rotterdam (Rhine-Meuse), Antwerp (Western Scheldt), and Hamburg (Elbe). Channel deepening reduces hydraulic friction, while land reclamation reduces the water storage capacity of estuaries. As a combined effect tidal penetration has increased in many estuaries (e.g. Friedrichs and Aubrey 1994). An increase in tidal range may increase the stirring of fine-grained sediments and so increase SSC towards highly turbid conditions, such as observed in the Ems estuary (e.g. Van Leussen 2011).

Other human impacts since the 1950s include the building of flood defence structures, such as storm surge barriers (e.g. Eastern Scheldt barrier; Thames barrier) and even the complete closure of estuaries by dams (e.g. Dutch Delta works). In the Eastern Scheldt estuary, the storm surge barrier seriously affects the sediment budget: as the tidal prism is reduced, the channels tend to fill in, but because marine import of sediments is restricted by the storm surge barrier, the intertidal flats inside the estuary experience erosion and sediments are redistributed towards the channels. 


\subsubsection{Future Expectations}

\subsubsection{Sea-Level Rise}

Aspects of climate change that are expected to affect the geomorphology of estuaries include accelerated SLR, increased storminess, and increased fluctuations in freshwater discharge. SLR is of particular concern for the geomorphology and ecology of intertidal flats and marshes. In some parts of the world (e.g. Mississippi Delta; Chesapeake Bay; Venice Lagoon), sediment accretion rates are not enough to compensate for relative SLR (i.e. eustatic SLR combined with local land subsidence), which has resulted over the last century in extensive die-back of marsh vegetation and conversion of marshes and mudflats into open water (e.g. Kearny et al. 2002). A recent study combining five state-of-the-art models of marsh sedimentation in response to SLR, revealed that marshes with a low tidal range and low SSC $\left(<20 \mathrm{mg} \mathrm{l}^{-1}\right)$ are especially at risk from submergence by average SLR projections (Kirwan et al. 2010). Based on Fig. 9.15, and given the large tidal ranges $(2-6 \mathrm{~m})$ and generally high SSC values (mostly $>20 \mathrm{mg} \mathrm{l}^{-1}$ and up to several hundreds of milligrams per litre) for estuaries around the North Sea, the risk of marsh submergence by SLR is low for the coming century. For example, for the Western Scheldt estuary (average SSC $\sim 40 \mathrm{mg} \mathrm{l}^{-1}$; mean tidal range $\sim 4 \mathrm{~m}$ ), marshes are expected to drown in the long term only if the rate of SLR increases to $50 \mathrm{~mm}$ year $^{-1}$, which is far more than expected by 2100 (Temmerman et al. 2004). In theory, SLR may also affect estuarine sediment regimes, as it may increase the landward penetration of tides and hence of the ETM, but only if morphodynamic changes in the estuary are assumed to be zero; however, estuarine morphodynamic changes and human impacts are likely to exert much more control over estuarine sediment regimes than SLR.

\subsubsection{Storms}

Although the precise effects of climate warming on increasing frequency and intensity of storms is subject to debate in the scientific literature, there is growing consensus that climate warming is expected to increase the intensity of extreme tropical and extra-tropical storms for many coastal areas worldwide (e.g. Knutson et al. 2010), including the North Sea (e.g. Knippertz et al. 2000; Leckebusch and Ulbrich 2004; Donat et al. 2010). Increasing storminess may have geomorphological effects as wind waves during storms may affect erosion and sedimentation processes, especially on intertidal flats and along marsh edges (e.g. Callaghan et al. 2010 and see Chap. 18). Wind waves are most important in the seaward, wider parts of the estuaries, where water surface and wind fetch length are longer so that higher

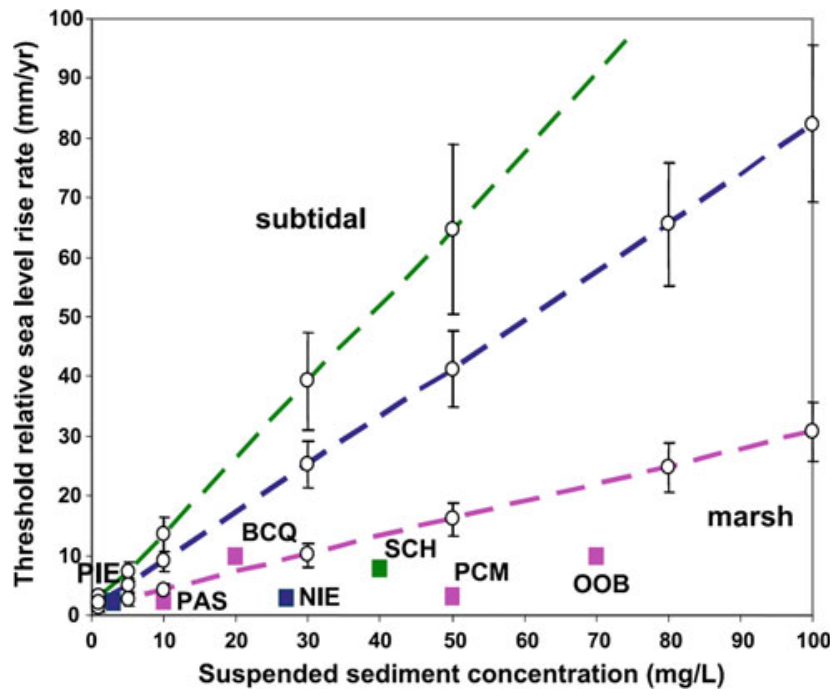

Fig. 9.15 Predicted threshold rates of sea-level rise, above which marshes are replaced by subtidal environments as the stable ecosystem. Each line represents the mean threshold rate $( \pm 1 \mathrm{SE})$ predicted by five models as a function of suspended sediment concentration and spring tidal range. The hatched line denotes thresholds for marshes modelled under a $1 \mathrm{~m}$ tidal range (pink), a $3 \mathrm{~m}$ tidal range (blue), and a $5 \mathrm{~m}$ tidal range (green). For reference, examples have been included (denoted with square markers) of marshes worldwide in estuaries with different rates of historical sea-level rise, sediment concentration, and tidal range. (PIE Plum Island Estuary, Massachusetts; PAS Pamlico Sound, North Carolina; $B C Q$ Bayou Chitique, Louisiana; NIE North Inlet Estuary, South Carolina; SCH Scheldt Estuary, Netherlands; PCM Phillips Creek Marsh, Virginia; $O O B$ Old Oyster Bayou, Louisiana) (after Kirwan et al. 2010)

storm waves can be generated, while in the more landward, smaller parts of the estuaries smaller wind waves are expected. For several North Sea estuaries, including the Greater Thames area (UK) and the Western Scheldt estuary (Netherlands), lateral erosion of the edges of intertidal flats and marshes has been reported and partly attributed to wind wave erosion (e.g. Van der Wal and Pye 2004; Van der Wal et al. 2008), which might increase with increasing storminess due to climate change. However, these studies also highlighted that the wind-wave climate is not the only variable explaining the patterns and rates of lateral marsh erosion, but that other factors also play a major role, including the larger-scale morphodynamic changes in estuarine channel position, which may be affected by human impacts such as dredging and disposal of sediments (e.g. Cox et al. 2003). Several studies also address the role of self-organising mechanisms, driven by feedbacks between marsh vegetation, sediment deposition and erosion, and wave hydrodynamics, leading to cycles of lateral marsh extension and lateral marsh erosion, that are not solely driven by external forcing factors such as storminess (Van de Koppel et al. 2005; Chauhan 2009; Mariotti and Fagherazzi 2010). 


\subsubsection{Precipitation}

According to the latest IPCC assessment, winter precipitation (October-March) in central and northern Europe (including the North Sea region) could be up to $40 \%$ higher than present-day by 2100 (this value includes the 5th to 95 th percentiles of precipitation projections for all IPCC scenarios) (Van Oldenborgh et al. 2013). For summer (AprilSeptember), climate models project a change in precipitation of $-10 \%$ to $+20 \%$ by 2100 . Although the range of projections is quite large, the IPCC projections clearly suggest a future increase in precipitation during winter, with a smaller increase or even a slight decrease, during summer. Larger fluctuations in freshwater river discharge may affect the terrestrial sediment supply to estuaries. More intense rainfall events, especially during winter, may induce larger soil erosion events within the river catchment of estuaries (e.g. Poesen et al. 2003), and so may increase the terrestrial sediment supply to estuaries, potentially contributing to higher SSC values in the ETM zone (see also Chaps. 11 and 13). However, it should be emphasised that in terms of runoff and sediment supply to estuaries and the coast, human impacts such as changes in land use within the river catchment of estuaries are often as important as or even more important than changes in precipitation (Syvitski et al. 2005).

\subsubsection{Human Impact}

It must be stressed that human impacts such as channel deepening for harbour accessibility and flood defence and shoreline protection structures on geomorphology and sediment transport in estuaries are very likely to continue over the coming decades, and may dominate, exacerbate or compensate for the potential impacts of climate change. Channel deepening is likely to exacerbate the increase in tidal range and landward tidal wave penetration over coming decades, increasing risk of sediment resuspension and a potential shift towards hyper-turbid conditions such as happened in the Ems estuary in the Netherlands over past decades (Winterwerp 2011). One particular example of mitigation of climate and human-induced impacts is the conversion and restoration of formerly reclaimed land into intertidal flats and marshes in the UK (so-called managed coastal realignment schemes, such as in the Humber and Blackwater estuaries) (French 2006b) and Belgium (the Sigma plan in the Scheldt estuary) (Maris et al. 2007). Other types of ecosystem-based adaptation to climate change ('soft engineering'), that are starting to be implemented, include the creation of oyster reefs and sand supply on tidal flats such as in the Eastern Scheldt estuary (e.g. Temmerman et al. 2013). Although such schemes provide multiple benefits in the form of ecosystem services (see E-Supplement S9) (e.g. flood storage, erosion protection, water quality regulation, carbon sequestration, fisheries production), societal opposition against conversion of reclaimed land into intertidal flats and marshes may be important and effects on changing tidal conditions in the estuary must be considered (see Temmerman et al. 2013 for a review).

In the Scheldt estuary, up to 3000 ha of historically reclaimed land are designated for conversion into floodplains, of which about 1500 ha are tidal marshes (Broeckx et al. 2011). The new intertidal areas have two objectives: to store extra water and attenuate landward propagating storm surges, thus reducing flood risk in the hinterland; and to provide ecosystem services such as water quality improvement and habitat restoration. Effects on the sediment budget of the estuary may also be expected (Maris et al. 2007). For example, in the Belgian part of the Scheldt estuary, the tidal marsh area is expected to increase from around 420 ha at present to almost 2000 ha by 2030. A pilot project showed that sediment accretion processes are already occurring in the newly created marshes at rates (per surface area) comparable to those on natural marshes (Vandenbruwaene et al. 2011), and so the completion of the whole marsh restoration scheme could reduce the risk of increasing SSC and turbidity within the estuary. Similar tidal marsh creation projects on formerly embanked land have been realised over the last few years and are planned for the near future in other estuaries around the North Sea, in particular in the Humber and Greater Thames estuaries (UK), where this management approach is called 'managed coastal realignment' (e.g. French 2006b; Turner et al. 2007).

The positive outcome of this management approach of tidal marsh creation on formerly reclaimed land should stimulate the wider implementation of this approach in other estuaries around the North Sea as a sustainable and cost-effective manner to mitigate climate- and humaninduced impacts.

\subsection{Salt Marshes}

Jan P. Bakker

\subsubsection{Distribution and Dynamics}

Salt marshes occur along an elevational gradient from the intertidal flats to middle and high marsh with an associated change in the composition of the vegetation (Fig. 9.16). Vegetation-sedimentation feedbacks are only one of the many potentially important interactions (Fig. 9.17) (Nolte et al. 2013a). The main external controls of sediment deposition are sea level (hydroperiod) and sediment supply. The latter is strongly related to the SSC. Interactions between the physical and biological features of salt marshes 




Fig. 9.16 Zonation of salt marshes in relation to the duration and frequency of tidal flooding and marsh elevation for the western German Wadden Sea. On back-barrier marshes the seawall is replaced by dunes (modified after Erchinger 1985). Eelgrass Zostera spp., glasswort Salicornia spp., common cordgrass Spartina anglica, seaside alkali grass Puccinellia maritima, sea purslane Atriplex portulacoides, red fescue Festuca rubra, sea couch Elytrigia atherica are the dominant

are also important. The accumulation of plant biomass can play an influential role in sediment deposition. Human impacts such as ditching or management practices such as livestock grazing (and then soil compaction) can also affect processes related to hydrodynamics, vegetation composition, and sediment deposition.

Although many salt marshes tend to have a 'natural' appearance, some along the mainland coast result from human interference. Salt marshes emerged about 2500 years BP after the last glacial period. Apart from small-scale embankments from the Roman period onward, most of the coastline became protected by seawalls about $1000 \mathrm{AD}$, thus reducing brackish marshes further inland and disconnecting them from the salt marshes. Peat reclamation along the coastline and subsidence behind the seawalls combined with sudden falls in the human population due to disease in the Medieval period, made the embankments vulnerable to attack by the sea. This resulted in societal collapse and a subsequent inability to maintain the seawalls that protected the embankments (Wolff 1992). This resulted in embayments such as the Lauwerszee, Dollard (the Netherlands), Leybucht (Germany), and subsequent new salt-marsh development. In past centuries, extensive areas of salt marsh have been embanked for coastal protection and agricultural exploitation (Dijkema 1987). Currently, a decline in the pioneer zone and increase in the high marsh zone in the Wadden Sea has been reported (Esselink et al. 2009). Since the 1960s it has not been economically viable to embank salt plant species. They may be replaced by other species in the northern North Sea region. Wind flood (Windflut) is defined as $92 \mathrm{~cm}+$ MHT, storm flood (Sturmflut) as $198 \mathrm{~cm}+$ MHT, hurricane flood (Orkanflut) as $275 \mathrm{~cm}+$ MHT. During a period of 20 years, they occur $\mathrm{n} \leq 10$ times, $10>\mathrm{n} \leq 0.5$, and $0.5>\mathrm{n} \leq 0.05$, respectively, in the western German Wadden Sea (Niemeyer 2015)

marshes for agricultural use (Wolff 1992). Accidental de-embankments after storm surges have occurred since the 19th century, and deliberate de-embankments in north-western Europe since the 1990s (Esselink et al. 2009). In terms of their future survival, it is important to understand the extent to which salt marshes can keep pace with the projected acceleration in SLR. An extreme episodic storm surge may destroy the vegetation at the marsh edge and cause the formation of a cliff (Van de Koppel et al. 2005). Feedbacks between sediment, vegetation and wave hydrodynamics may result in the formation of new marshes (see Sect. 9.5.3.2). Estuarine marshes in south-east England suffer from erosion. An overview of erosion rates revealed a net loss in area between 1973 and 1998 of about 1000 ha, or $33 \%$. Recent erosion rates (1988-1998) have been slower however (Cooper et al. 2001) and the area covered has recently (2006-2009) increased, resulting in a loss of 'only' 750 ha since 1973 (Phelan et al. 2011).

Lateral erosion can result in a narrowing of salt marshes, or coastal squeeze (Wolters et al. 2005a), particularly in the case of a short foreshore (Bouma et al. 2014) (see also Chap. 18). The potential loss of salt-marsh area through erosion from the seaward edge appears unrelated to the sedimentation processes in the salt marsh itself, but is determined by sedimentation in the pioneer zone, thus allowing dynamic rejuvenation of the lower salt marsh (Boorman et al. 1989; Dijkema et al. 2010), as in the case of a wide foreshore (Bouma et al. 2014). A wider foreshore will 


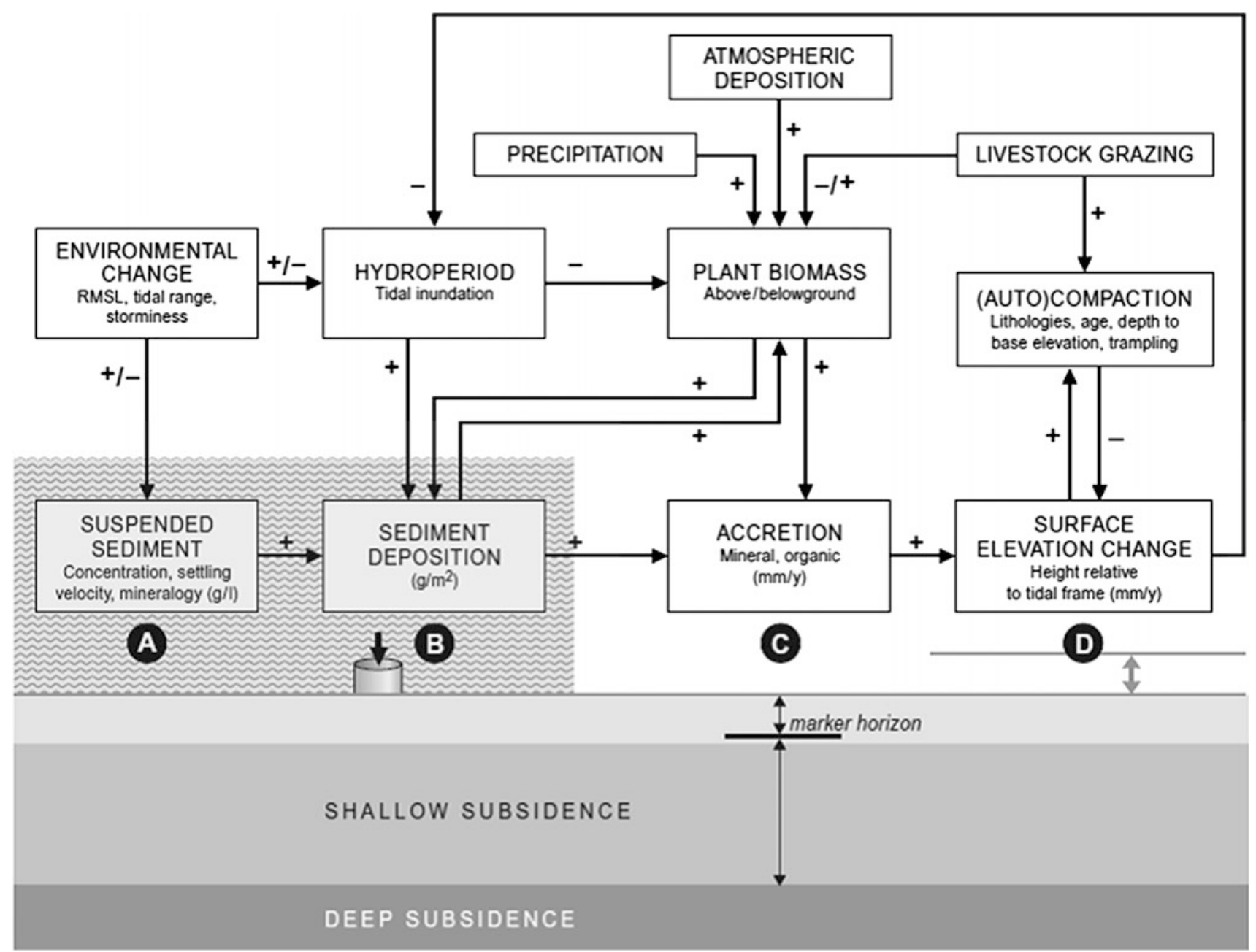

Fig. 9.17 Factors affecting sedimentation and accretion processes in coastal marshes. The letters $A, B, C$, and $D$ indicate the main factors considered in the review (after Nolte et al. 2013a)

inherently offer more space for intertidal ecosystems. Moreover, a wider foreshore will generally have weaker wave energy gradients than a narrower foreshore, thereby making it easier for epibenthic ecosystems to establish. As a result, both the maximum and minimum widths of an intertidal habitat will have a positive relationship with the size of the foreshore (Fig. 9.18). Self-organisation of this type is enhanced by the wave reduction of up to $60 \%$ attributed to vegetation compared to bare soil (Möller et al. 2014). Sea-edge erosion may result in large-scale cliff erosion. If cliff erosion is not prevented by groynes, marshes established from sedimentation fields may disappear in the long term (Dijkema 1994).

The area covered by salt marshes in the North Sea region has increased following accidental de-embankments after breaching of the seawall or summerdike during storm surges, such as occurred in 1953. Accidental de-embankments took place at 35 sites in north-western Europe before 1991. After 1991, deliberate de-embankment took place at 29 sites, and there are plans to increase this number. The de-embanked sites ranged from less than 1 ha to over 500 ha. The total area amounted to more than 5600 ha (Wolters et al. 2005b). Half of the deliberate de-embankments were carried out for habitat restoration and a quarter for flood defence (see E-Supplement S9 for ecosystem services) (Fig. 9.19).

Past SLR is not the same along the entire coastline of the North Sea, nor is it constant over time (Table 9.1 in Sect. 9.2.3.1). Global mean SLR was about $1.7 \mathrm{~mm}_{\text {year }}{ }^{-1}$ for the 20th century as a whole, but was higher at about $3 \mathrm{~mm}$ year $^{-1}$ over the last two decades. These data hold for most of the European coasts, but with variations due to local land movement, either positive or negative (EEA 2012). Mean SLR for the North Sea region over the past 20 years ${ }^{1}$ is $1.4 \pm 0.4 \mathrm{~mm}$ year $^{-1}$. A recent analysis of data from Dutch

\footnotetext{
${ }^{1}$ http://ibis.grdl.noaa.gov/SAT/SeaLevelRise/slr/slr_sla_nrs_free_all_ 66.pdf.
} 




Fig. 9.18 Schematic illustration of the relation between foreshore dimensions and the maximum and minimum widths of an intertidal ecosystem with wave-attenuating aboveground (epibenthic) structures. The maximum and minimum widths relate to the borders reached by intertidal ecosystems with cyclical dynamics: the minimum width is the size of the ecosystem that will maintain, whereas everything between the maximum and minimum will vary over time. A sufficiently wide

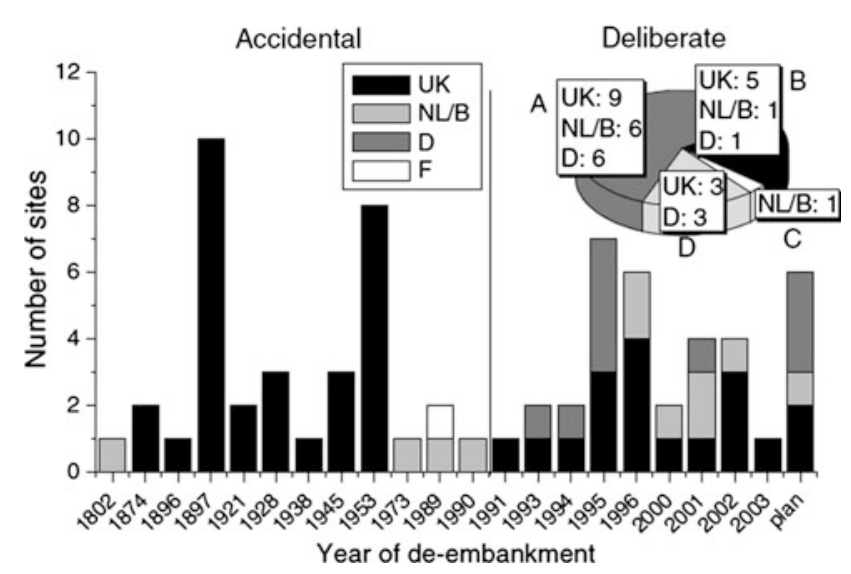

Fig. 9.19 Timing and causes of salt marsh de-embankment by country. a habitat creation or restoration; b flood defence; c gaining experience; d unknown (Wolters et al. 2005b)

tidal stations does not show an acceleration in SLR between 1990 and 2010 (Dillingh et al. 2012). SLR can be affected by vertical land movement. This varied from -1.3 to $0.1 \mathrm{~mm}$ year $^{-1}$ over the period 1843-2009 in the German Bight (Wahl et al. 2011) and from -1.1 to $-0.5 \mathrm{~mm}$ year $^{-1}$ in the English Channel through the 20th century (Haigh et al. 2011).

Not only has mean SLR changed over time, but MHT has also varied in different locations and over different periods foreshore is important to enable epibenthic intertidal ecosystems to go through natural cycles of decay and re-establishment (cf. Van de Koppel et al. 2005), without experiencing coastal squeeze. On a narrow foreshore, re-establishment of degrading epibenthic ecosystems may be hampered by gradients in wave energy that are too strong (Bouma et al. 2014)

(Table 9.2). For a given area, the rate of change in MHT was sometimes higher that SLR, sometimes lower, or was even negative.

\subsubsection{Sedimentation and Accretion in Intertidal Marshes}

Whether coastal marshes can cope with accelerated SLR depends on the change in surface elevation, which in turn depends on availability of sediment (SSC), over marsh tidal events, and autocompaction. These interact with plant biomass and exploitation of salt marshes by livestock grazing (Fig. 9.17). Rates of surface elevation change (SEC) of a broad sample of allochthonous marshes in north-western Europe and North America range from a few millimetres per year to several centimetres per year. There is no obvious trend with tidal range, but the envelope of variability is wider at larger tidal ranges. The sites included no evidence for SEC deficit (i.e. the difference between rates of SEC and SLR) with the exception of a single system (French 2006a).

Accretion and SEC are both often expressed as an average for a given area, including a range on individual measurements. Salt marshes along the mainland coast of the North Sea region reveal higher rates of accretion or SEC than those on barrier islands (Table 9.3). 
Table 9.2 Regional variation in change in mean high tide (MHT) within the North Sea region

\begin{tabular}{l|l|l|l}
\hline Area & Change in MHT, mm year & Period & Source \\
\hline Wadden Sea & $2-2.5$ & $1950-2000$ & Oost et al. (2009) \\
\hline Germany-mainland & 4.2 & $1965-2001$ & Jensen and Mudersbach (2004) \\
\hline Germany-islands & 3.5 & $1965-2001$ & Jensen and Mudersbach (2004) \\
\hline Ameland, Netherlands & 6 & $1963-1983$ & Dijkema et al. (2011) \\
\hline New Statenzijl, Dollard, Netherlands & 0 & $1983-2010$ & Dijkema et al. (2011) \\
\hline & 5.7 & $1890-1910$ & Esselink et al. (2011) \\
\hline & 1 & $1910-1954$ & Esselink et al. (2011) \\
\hline & 6 & $1955-1983$ & Esselink et al. (2011) \\
\hline
\end{tabular}

Table 9.3 Regional variation in mean rates of accretion (AC), surface elevation change (SEC) or a combination of the two on salt marshes in the North Sea region

\begin{tabular}{|c|c|c|c|}
\hline Area & AC/SEC mm year ${ }^{-1}$ & Period & Source \\
\hline \multicolumn{4}{|l|}{ Mainland } \\
\hline Friesland, Netherlands & 11-29 SEC & 1984-2010 & Dijkema and Van Duin (2012) \\
\hline Peazemerlannen, Netherlands & 9-14 SEC & $1996-2010$ & Dijkema and Van Duin (2012) \\
\hline Groningen, Netherlands & 8-14 SEC & 1984-2010 & Dijkema and Van Duin (2012) \\
\hline Dollard, Netherlands & 7-10 SEC & 1984-2003 & Dijkema and Van Duin (2012) \\
\hline Schleswig-Holstein south, Germany & 2-3 SEC & 1998-2009 & Suchrow et al. (2012) \\
\hline Schleswig-Holstein north, Germany & 5-9 SEC & $1998-2009$ & Suchrow et al. (2012) \\
\hline Hamburger Hallig, Germany & 4-17 SEC & 1996-2009 & Stock (2011) \\
\hline \multicolumn{4}{|l|}{ Back-barrier } \\
\hline Stiffkey, UK & 6.5 AC/SEC & $1995-1998$ & Cahoon et al. (2000) \\
\hline Terschelling, Netherlands & 1.3 AC/SEC & $1995-1998$ & Van Wijnen and Bakker (2000) \\
\hline Schiermonnikoog, Netherlands & 0-3 AC/SEC & $1995-1998$ & Van Wijnen and Bakker (2000) \\
\hline Rømø, Denmark & $2.6 \mathrm{AC}$ & $1980-2003$ & Pedersen and Bartholdy (2006) \\
\hline Fanø, Denmark & $2.8 \mathrm{AC}$ & 1980-2003 & Pedersen and Bartholdy (2006) \\
\hline Skallingen, Denmark & $2.4 \mathrm{AC}$ & 1980-2003 & Pedersen and Bartholdy (2006) \\
\hline Skallingen, Denmark & 1.4 AC/SEC & $1995-1998$ & Van Wijnen and Bakker (2000) \\
\hline
\end{tabular}

Data on the age of salt marshes in Table 9.3 are not often available. In contrast, age data are available for back-barrier marshes and these indicate decreasing SEC with increasing age of the marsh (Van Wijnen and Bakker 2001). SEC was $2.5 \mathrm{~mm} \mathrm{year}^{-1}$ on a marsh of up to 15 years in age, around $1.5 \mathrm{~mm} \mathrm{year}^{-1}$ on a marsh of 30 years in age, and around $0 \mathrm{~mm}$ year $^{-1}$ on a marsh of 100 years in age (Fig. 9.20). Decreasing SEC in older marshes may indicate autocompaction (see Sect. 9.4).

In addition to regional differences in SEC, there are also local differences from high marsh to intertidal flats. At the barrier island of Langli, Denmark, an accretion rate of $-1 \mathrm{~mm}$ year $^{-1}$ (2001-2009) was recorded on the high marsh and $0.5 \mathrm{~mm}$ year $^{-1}$ on the low marsh (Kuijper and Bakker 2012). On the mainland marsh of the Dollard estuary in the Netherlands, the accretion rate was $9-16 \mathrm{~mm}$ year $^{-1}$ at $10 \mathrm{~cm}+$ MHT and $0-8 \mathrm{~mm}$ year $^{-1}$ at $55 \mathrm{~cm}+$ MHT over the period 1984-1991 (Esselink et al. 1998). Plots at 20$60 \mathrm{~cm}+$ MHT revealed a SEC of 5-9 $\mathrm{mm} \mathrm{year}^{-1}$, while plots at $70-80 \mathrm{~cm}+$ MHT showed only $1 \mathrm{~mm} \mathrm{year}^{-1}$ for the period 1996-2009 in the mainland marsh of Hamburger Hallig on the German coast. Rates of accretion or SEC were generally higher near the salt-marsh edge in both mainland and back-barrier marshes (Table 9.4). However, this was not found at the southern side of Hamburger Hallig, indicating strong local differences (Stock 2011). Rates were higher on mainland marshes than back-barrier marshes (see also Table 9.3).

The rate of accretion also declines away from creeks and ditches in the mainland marshes of the Dollard; $15 \mathrm{~mm}$ year $^{-1}$ next to a creek and $2 \mathrm{~mm}$ year $^{-1}$ (over 1984-1991) at $20 \mathrm{~m}$ from the creek at a distance of $750 \mathrm{~m}$ from the marsh edge (Esselink et al. 1998). Apparently water with very little sediment in suspension inundates the marsh far from the 


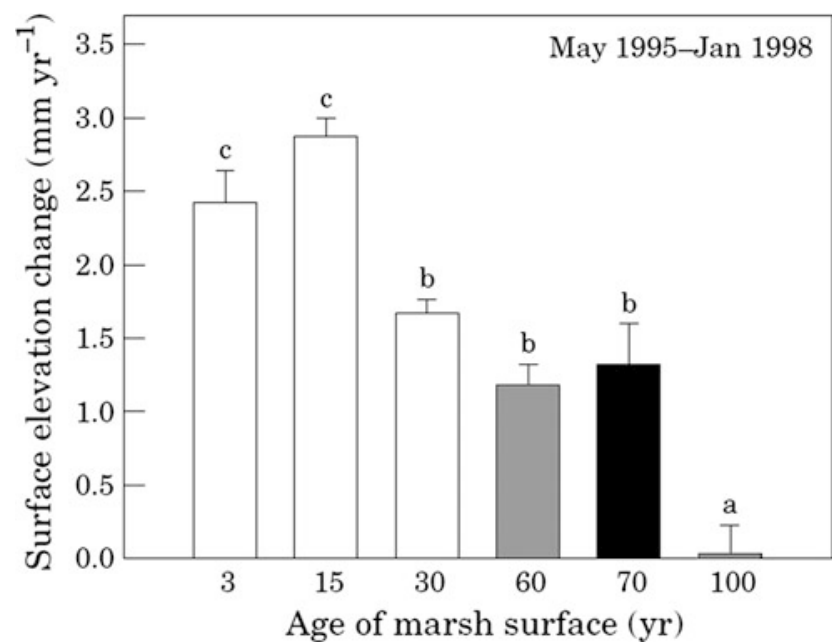

Fig. 9.20 Marsh surface elevation change at $40 \mathrm{~cm}+$ MHT in the late 1990s over a three-year period in salt marshes at various successional stages on the ungrazed back-barrier marshes of Schiermonnikoog, the Netherlands (open bars), Terschelling, the Netherlands (grey bar) and Skallingen, Denmark (black bar). Different letters indicate significant differences $(p<0.05)$ (Van Wijnen and Bakker 2001)

edge. Sediment trapping at the marsh edge is enhanced by plants causing wind wave attenuation (Möller 2006).

Data from a broad sample of allochthonous marshes in north-western Europe and North America, reveal only weak positive linkages between SSC and mean tidal range (French 2006a). Variability in SSC is dependent on the weather conditions. In the eastern Wadden Sea in the Netherlands, SSC of up to $100 \mathrm{mg} \mathrm{l}^{-1}$ was recorded during most tides, but could increase to $800 \mathrm{mg} \mathrm{l}^{-1}$ during periods of strong western winds (Kamps 1962). Elevated SSC due to wave re-suspension correlates with strong westerly wind events. These local meteorological events seem to overrule sea level and tidal range (French 2006a). An increase in extreme sea level during storm surges in the southern North Sea was



Fig. 9.21 Comparison of accretion rate using Sedimentation Erosion Bar (SEB) measurements for 2 years and 15 years. Measurements took place on levees, in the low marsh, and in basins at the Peazemerlannen mainland salt marsh in the Netherlands. The two-year measurements represent a period without winter storms (Nolte et al. 2013a)

found over the period 1850-2000 (Weisse et al. 2012). Wave activities can re-mobilise sediment, especially with onshore winds. However, surges are not always accompanied by strong onshore winds.

Spatial differences in accretion are also found. On the levees, low marsh and depressions in the mainland marsh of Peazemerlannen in the Netherlands, the rate of accretion was higher during a period that included winter storms than periods without (Nolte et al. 2013a) (Fig. 9.21). Most sediment originates offshore (see Sect. 9.4.1), the rest is mobilised from adjacent intertidal flats during storms.

Measurements of SEC over six years along the mainland coast of Friesland in the Netherlands, revealed many floodings of the salt marsh with high tides plus storm surges $\geq 0.90 \mathrm{~m}+$ MHT in the period 2002/03-2006/07. A positive relationship was found between the cumulative water column per storm year above the salt marsh and annual SEC for the high marsh $(0.57-0.85 \mathrm{~m}+$ MHT) and low marsh (0.24-0.34 m + MHT) (Fig. 9.22). Esselink and Chang

Table 9.4 Average rates of accretion (AC) or surface elevation change (SEC) on salt marshes within the North Sea region, at different distances from the salt-marsh edge

\begin{tabular}{|c|c|c|c|c|}
\hline Area & \multicolumn{2}{|c|}{$\begin{array}{l}\left.\text { AC/SEC (mm year }{ }^{-1}\right) \text { distance to } \\
\text { edge }\end{array}$} & Period & Source \\
\hline \multicolumn{5}{|l|}{ Mainland } \\
\hline Dengie Peninsula, UK & $22(50 \mathrm{~m})$ & $11(200 \mathrm{~m})$ & $1981-1983$ & Reed (1988) \\
\hline \multirow[t]{2}{*}{ Hamburger Hallig, Germany } & $17(50 \mathrm{~m})$ & $4(650 \mathrm{~m})$ & 1996-2009 & Stock (2011) \\
\hline & $22(50 \mathrm{~m})$ & $1-2(1000 \mathrm{~m})$ & 1995-1999 & Schröder et al. (2002) \\
\hline Schleswig-Holstein, Germany & $8(100 \mathrm{~m})$ & $4(400 \mathrm{~m})$ & 1988-2009 & Suchrow et al. (2012) \\
\hline Dollard, Netherlands & $12-16(50 \mathrm{~m})$ & $2-5(800 \mathrm{~m})$ & 1984-1991 & Esselink et al. (1998) \\
\hline \multicolumn{5}{|l|}{ Back barrier } \\
\hline Langli, Denmark & $0.5(50 \mathrm{~m})$ & $-1(150 \mathrm{~m})$ & $2001-2009$ & Kuijper and Bakker (2012) \\
\hline Norfolk, UK & $4.5(50 \mathrm{~m})$ & $3.4(200 \mathrm{~m})$ & 1986-1991 & French and Spencer (1993) \\
\hline Skallingen, Denmark & $4.2(50 \mathrm{~m})$ & $1.6(750 \mathrm{~m})$ & 1948-1998 & Bartholdy et al. (2004) \\
\hline
\end{tabular}


(a)

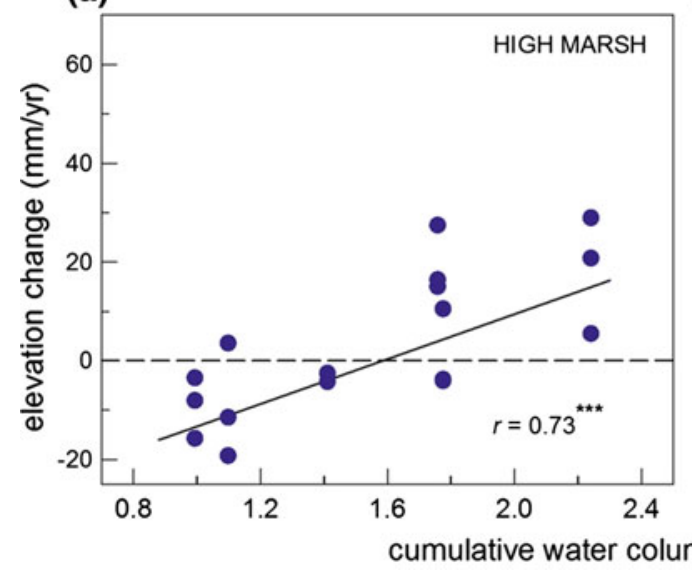

(b)



Fig. 9.22 Relation between the annual surface elevation change of the salt marsh and the cumulative water column above $0.9 \mathrm{~m}+$ MHT for each storm year (index) along the mainland coast of Friesland in the Netherlands between 2002 and 2007 for the high marsh (a) and the low marsh (b). Regression lines are based on a joint regression-analysis of the various stations, each station includes three replicates (after Esselink and Chang 2010)

Jefferies and Perkins (1977). Nitrogen accumulates during succession in the nitrogen pool of organic matter in the increasing layer of sediment and decaying plants and roots, and N-mineralisation increases with age of the marsh (Van Wijnen et al. 1997). This can be enhanced by the current high rates of atmospheric nitrogen deposition. Although the quantity of plant biomass increases during succession, the quality (more stems that are less palatable) decreases. Hence, the numbers of small herbivores such as winter-staging geese and resident hares and rabbits decrease during succession, after peaking in early successional stages (Van de Koppel et al. 1996). These smaller herbivores need livestock to facilitate for them (Bos et al. 2005).

\subsubsection{Livestock Grazing}

Livestock grazing on European salt marshes can be traced back a couple of millennia (Davy et al. 2009). Older back-barrier marshes are grazed by livestock as mainland marshes. Traditionally many salt marshes were intensively grazed by sheep or cattle (see E-Supplement S9 for ecosystem services). As a result the majority of these marshes were covered by an extremely short homogeneous vegetation of seaside alkali grass Puccinellia maritima or red fescue Festuca rubra (Kiehl et al. 1996). In the 1980s, grazing by livestock was reduced by up to $60 \%$ on back-barrier marshes and up to $40 \%$ in mainland marshes in the Wadden Sea in 2008 (Esselink et al. 2009). Alongside this change in management regimes there has been an increase in the abundance of the late-successional tall grass species sea couch Elytrigia atherica on several salt marshes along the North Sea coast, for example on the Wash, UK (Norris et al. 1997), Schiermonnikoog in the Netherlands (Van Wijnen et al. 1997) and Schleswig-Holstein in Germany (Esselink et al. 2009). There shes was demonstrated in west-European salt marshes by 
are high numbers of geese and hares on livestock-grazed salt marshes, and low numbers on long-term ungrazed marshes along the coasts of the Wadden Sea (Bos et al. 2005). When grazing ceased, intensive ditching was often discontinued. This resulted in a wetter marsh and reduced spread of sea couch (Veeneklaas et al. 2013).

At the Leybucht, Germany, SEC of $17 \mathrm{~mm}_{\text {year }}{ }^{-1}$ $(1980-1988)$ at $40 \mathrm{~cm}+$ MHT was measured in cattle-grazed marsh, but was higher at $23 \mathrm{~mm} \mathrm{year}^{-1}$ in the abandoned marsh (Andresen et al. 1990). SEC was about $7 \mathrm{~mm}$ year $^{-1}$ over 1996-2009 on ungrazed or low-density grazing on mainland marshes of Hamburger Hallig, Germany. It was however, reduced to $4 \mathrm{~mm} \mathrm{year}^{-1}$ at sites with high grazing density (Stock 2011). In mainland marshes of the Dollard estuary, intensively grazed sites showed accretion rates of about $8 \mathrm{~mm}$ year ${ }^{-1}$ and little-grazed sites about $12 \mathrm{~mm} \mathrm{year}^{-1}$ over 1984-1991 (Esselink et al. 1998). In Schleswig-Holstein, grazed sites showed an SEC of 3$4 \mathrm{~mm}$ year $^{-1}$ and ungrazed sites $8 \mathrm{~mm} \mathrm{year}^{-1}$ over 1988 2009 (Suchrow et al. 2012). Grazing reduces SEC. However, this is not due to a lower input of sediment in grazed sites, but to an increase in the bulk density of the soil in both a back-barrier marsh (Elschot et al. 2013) and in mainland marshes (Nolte et al. 2013b).

\subsubsection{Climate Change and Salt Marshes}

\subsubsection{Sea-Level Rise}

Back-barrier marshes with a low vertical accretion might be affected by SLR earlier than mainland marshes with a higher vertical accretion. With little sediment input and continuous SLR, a salt marsh gets wetter, thus preventing the spread of the late successional sea couch Elytrigia atherica on Hamburger Hallig even without livestock grazing (Esselink et al. 2009). On the back-barrier marsh of Schiermonnikoog, sea couch has been replaced by the reed Phragmites australis,

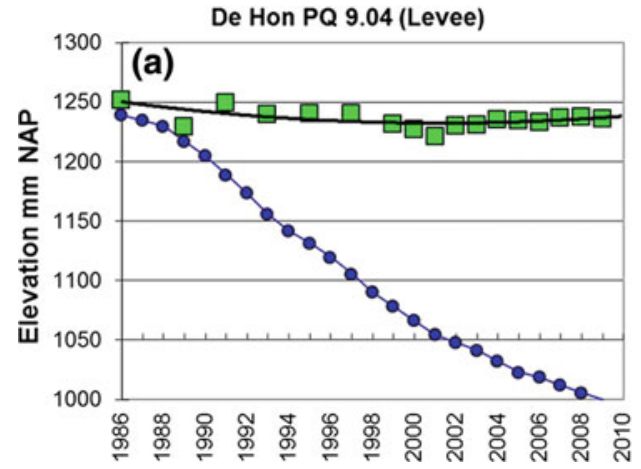

Fig. 9.23 Surface elevation change in the period 1986-2009 (green) resulting from soil subsidence due to natural gas extraction (blue) and accretion measured near the salt-marsh edge on a creek bank levee far from the salt-marsh edge (Veeneklaas et al. 2013). This suggest that on broad salt marshes geomorphological changes may occur, resulting in growing differences in elevation, that is, high salt-marsh edge and creek bank levees, and lower depressions between creeks. Especially at the foot of dunes releasing fresh seepage water, brackish conditions can develop.

Accelerated SLR is believed to affect the zonation of salt-marsh plant communities: high salt-marsh communities should turn into lower salt-marsh communities (see Fig. 9.16) (Dijkema et al. 2011). Accelerated SLR can be modelled, but it is not known what will actually happen in reality. An unintended experiment (unique in the North Sea region) taking place as a result of natural gas extraction for energy on the back-barrier salt marsh of Ameland in the Netherlands, may give some idea. Gradual soil subsidence of up to $35 \mathrm{~cm}$ by 2050 is expected close to the extraction point (Dijkema 1997). After 25 years, the maximal subsidence is about $25 \mathrm{~cm}$. Near the salt-marsh edge, subsidence is totally counteracted by accretion, with an SEC of zero. About $300 \mathrm{~m}$ from the marsh edge, only $4 \mathrm{~cm}$ accretion was measured, thus an SEC of $-21 \mathrm{~cm}$ (Fig. 9.23). Permanent plot data show no decrease in the late successional grass sea couch. At the scale of the salt marsh, however, data from repeated vegetation mapping do show some decrease in the sea couch community (Dijkema et al. 2011). To date, there has been little change in the zonation of plant communities. The future will show whether $25 \mathrm{~cm}$ subsidence is sufficient to cause vegetation change, or whether there is a time lag in the response of the vegetation.

Observations of vegetation composition, elevation, soil chemistry, net precipitation, groundwater level, and flooding frequency over the period 1986-2001 were used to predict future changes at the transition between salt marsh and dune due to the combination of ongoing soil subsidence and climate change at the barrier island of Ameland. Climate change was characterised by increases in mean sea level,

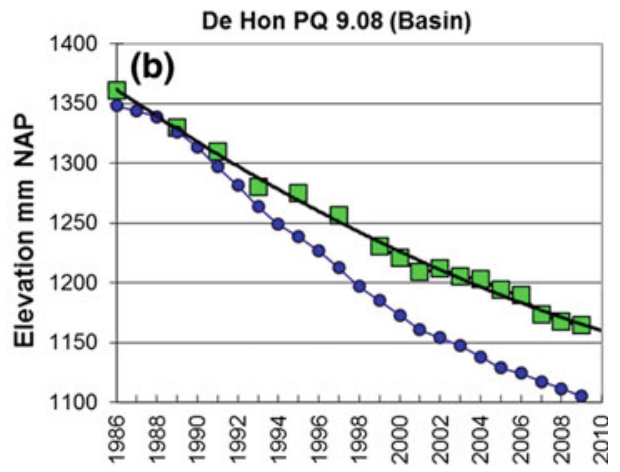

(a) and about $300 \mathrm{~m}$ from the salt-marsh edge in a depression (b) (after Dijkema et al. 2011) 
storm frequency and net precipitation. Using multiple regression, changes in the vegetation could be subdivided into (1) an oscillatory component due to fluctuations in net precipitation, (2) an oscillatory component due to incidental flooding, (3) a monotonic component due to soil subsidence, and (4) a monotonic component not related to any measured variable but probably due to eutrophication. The changes were generally small during the observation period (19862001), but the regression model suggests large changes by 2100 that are almost exclusively due to SLR. Although SLR is expected to cause a loss of plant species, this does not necessarily imply a decrease in nature conservation interest; while common species may be lost rarer species may persist (Van Dobben and Slim 2012).

Comparison of the zonation of beetles and spiders in present mainland salt marshes, and laboratory experiments with enhanced SLR, suggested that species of the lower marsh will move to higher elevation, but species of the higher marsh are unable to escape to higher elevations owing to the barrier of the seawall. These results were interpreted as an example of coastal squeeze (Irmler et al. 2002). Similarly, the lowest-lying vegetation zones will increase at the expense of upper vegetation zones in salt marshes in Denmark with enhanced SLR, according to modelling studies (Moeslund et al. 2011). However, this finding contradicts the previously mentioned results of soil subsidence through gas extraction, which showed no change in the vegetation (Dijkema et al. 2011).

\subsubsection{Precipitation and Temperature}

Although annual deviations from long-term averages are important, there is a general trend of increasing precipitation and rising temperature in the North Sea region. Changes in precipitation may affect plant production (De Leeuw et al. 1990) and plant communities, especially those above MHT (De Leeuw et al. 1991). Long-term trends in precipitation are discussed in Chap. 2 (past) and Chap. 5 (future projections).

Critical loads of atmospheric nitrogen deposition indicate the threshold amount at which ecosystems change dramatically by encroachment of grasses and subsequent loss of species. The empirical range of critical atmospheric nitrogen deposition for 'Pioneer and low-mid salt marshes' has been adjusted in the most recent review (Bobbink et al. 2010) to $30-40 \mathrm{~kg} \mathrm{~N}$ ha $^{-1}$ year $^{-1}$. This range is considered as expert judgment for EUNIS type A2.64 and A2.65. The critical deposition load is now $22 \mathrm{~kg} \mathrm{~N}^{-1}$ year $^{-1}$ (1571 mol N $\mathrm{ha}^{-1}$ year $^{-1}$ ) for salt marshes in the Netherlands (Van Dobben and Slim 2012).

Accelerated SLR will have impacts perpendicular to the coastline. In contrast, temperature may have effects parallel to the coastline. The distribution of plant species of salt marshes and dunes may shift along the coast. Based on present patterns of distribution, annual temperature and winter precipitation, Metzing (2010) proposed a model to predict changes in distribution resulting from climate change. An increase of $2.5{ }^{\circ} \mathrm{C}$ in annual temperature and $15 \%$ more winter precipitation by 2050 is projected to result in a loss of $16 \%$ of plant species in the Wadden Sea (see also Sect. 9.3.4).

\subsection{Coastal Birds}

\section{Martijn van de Pol}

Coastal birds are typically distinguished from seabirds in that they rely heavily on coastal areas for their food instead of the open sea, although the distinction is not always clear-cut. Coastal and seabirds are phylogenetically closely related and many are part of the same order of Charadriiformes. When discussing the impact of climate change on coastal birds, a rather broad definition of coastal birds is taken here by not only including the large group of waders (sometimes also called shorebirds), but also by including other species that depend heavily on coastal areas for feeding, such as Eurasian spoonbills Platalea leucorodia, common eider duck Somateria mollissima and various species of terns, geese and gulls. The focus is not on birds that use coastal habitat solely for the purpose of breeding (such as some songbirds).

Since by definition coastal birds rely on coastal areas for their food, they live in the vicinity of coastal shallow waters such as estuaries and intertidal flats and can breed on sandy shores and salt marshes (cliff coasts are generally the domain of seabirds). A substantial proportion of all coastal birds in the North Sea region breed locally, but many others are migratory (e.g. geese) that breed elsewhere (e.g. Arctic), and only use estuaries around the North Sea to overwinter. This distinction between resident and migratory birds is important, as migratory birds may also be impacted by climate change outside the North Sea region.

There is overwhelming evidence from around the globe that the distribution and population size of many bird populations are changing as a direct result of climate change (for an overview see Møller et al. 2010). Around ten species of coastal birds (both breeding and migratory) are declining in parts of the North Sea, such as the Wadden Sea that spans the Netherlands, Germany and Denmark (Fig. 9.24) and estuaries in the United Kingdom (Risely et al. 2012). The functional diversity, however, does not decline (Mendez et al. 2012). But because coastal birds are rarely used as a model system to investigate the effects of climate change, very little is known about the general role that climate change may play in causing changes in numbers of coastal birds in the North Sea region (Ens et al. 2009). Nor is it well understood which species are likely to be adversely affected by climate change and which are likely to benefit. 



4 Fig. 9.24 Recent changes in numbers of breeding (top) and migratory (bottom) coastal birds in the Danish-German-Dutch Wadden Sea estuary. Dark blue columns indicate species with significant, increasing numbers; light blue columns indicate species with stable numbers and orange columns indicate species with significant, decreasing numbers (Koffijberg et al. 2009; Laursen et al. 2010)

Nevertheless, one of the aims of this section is to illustrate that although current knowledge about the climate change impact on coastal birds is limited, recent and future climate change are expected to profoundly affect coastal avian communities.

This section focuses on the few available studies on coastal birds from the North Sea region, supplemented by studies from outside the area to help with interpretation. This involves a consideration of those aspects of climate that might be changing and how these may affect coastal birds (Sect. 9.7.1), a review of the ways in which bird populations may respond to climate change, such as the timing of key annual events (migration and egg laying) and changes in reproduction and survival (Sect. 9.7.2), and an examination of how changes in coastal bird population numbers and in distribution range are interpreted in the light of direct and indirect influences of recent climate variability (Sect. 9.7.3).

\subsubsection{Effects of Climate Change on Birds}

Weather variables such as air and sea temperature, and amounts of precipitation are changing. Intra- and interannual variability in these weather variables, temporal autocorrelation and the frequency of extreme events can also change over time, which may all affect population dynamics of coastal birds (Van de Pol et al. 2010a, b, 2011). However, climate may not change at the same rate throughout the year or in different parts of the world, and this can lead to phenological mismatches in food webs (Visser 2008) and require readjustment of migration schedules (Bauer et al. 2008).

Global warming is causing both air and water temperatures to rise. Air temperatures directly affect the energetic expenditure and thereby food requirements of birds, particularly in small species during winter (Kersten and Piersma 1987). Many benthic and fish species that are prey items of coastal birds are strongly dependent on sea temperatures for growth, reproduction and survival (see also Chap. 8, Sect. 8.4). Severe winters can cause high mortality among many invertebrates, but these same cold winters can also cause shellfish to lose less body mass (Honkoop and Beukema 1997) and result in a good spatfall (Beukema 1992). Thus, it has been suggested that global warming is already 
Fig. 9.25 Period during which birds have nests that are sensitive to flooding (eggs or young chicks in the nest) and the mean nest elevation (compared to Mean High Tide) of six salt-marsh breeding species (upper). Increase in daily flooding risk of the lower parts of the salt marsh from 19711989 (black circles) to 19902008 (grey circles) (lower) (Van de Pol et al. 2012)

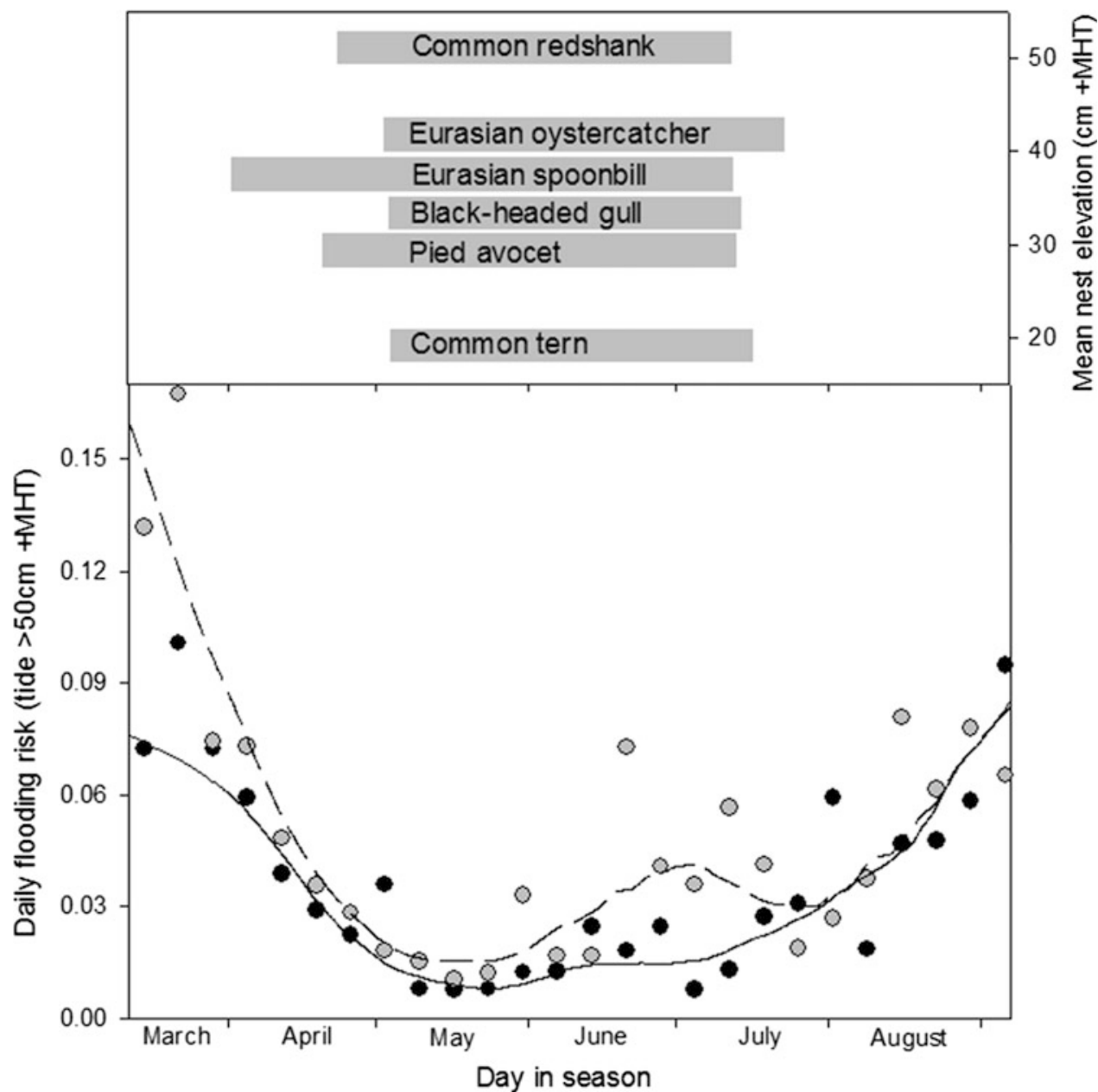

causing reduced recruitment of shellfish (Beukema and Dekker 2005; Beukema et al. 2009) and a shift in benthic community structure towards less cold-resistant species (e.g. Schückel and Kröncke 2013). Furthermore, invasion of exotic warm-water species, such as Pacific oyster Crassostrea gigas which is eaten by few birds, may result in increased competition for existing benthic species (Diederich et al. 2004).

Global warming also causes sea water to expand and land ice to melt thereby directly causing sea levels to rise. Accelerating SLR can have various consequences. The inundation time of intertidal flats may increase or flats used as feeding grounds may become completely inaccessible if sedimentation does not keep up (Flemming and Bartholomä 1997). Accelerated SLR in combination with changing wind patterns (there is currently no definitive evidence in this region for the latter due to the challenge of down-scaling future wind states from coarse resolution climate models) (Van Oldenborgh et al. 2013) can also affect breeding populations on land, as many bird species nest on low salt marshes and beaches that are susceptible to tidal (storm) flooding during the breeding season (Fig. 9.25; Hötker and
Segebade 2000; Van de Pol et al. 2010a). Over the long-term, SLR may result in loss of breeding habitat if boundaries such as dunes or seawalls mean that salt marshes cannot move landwards ('coastal squeeze'; Sect. 9.2.3).

Extreme events may also change in frequency and/or magnitude (Jentsch et al. 2007). In the Netherlands, precipitation and temperature extremes are expected to increase, with more heat waves in summer and higher temperature minima in winter and higher temperature maxima in summer, respectively (KNMI 2014). For example, global warming is expected to decrease the frequency of extremely cold winters in which ice sheets form on intertidal flats. Ice sheets make feeding areas inaccessible and if conditions prevail for long periods, they are known to result in large-scale frost migration and mass mortality of coastal birds (e.g. Camphuysen et al. 1996).

\subsubsection{Responses to Climate Change}

Individual birds may respond in various ways to a changing environment. Changes in the timing of reproduction (Crick 


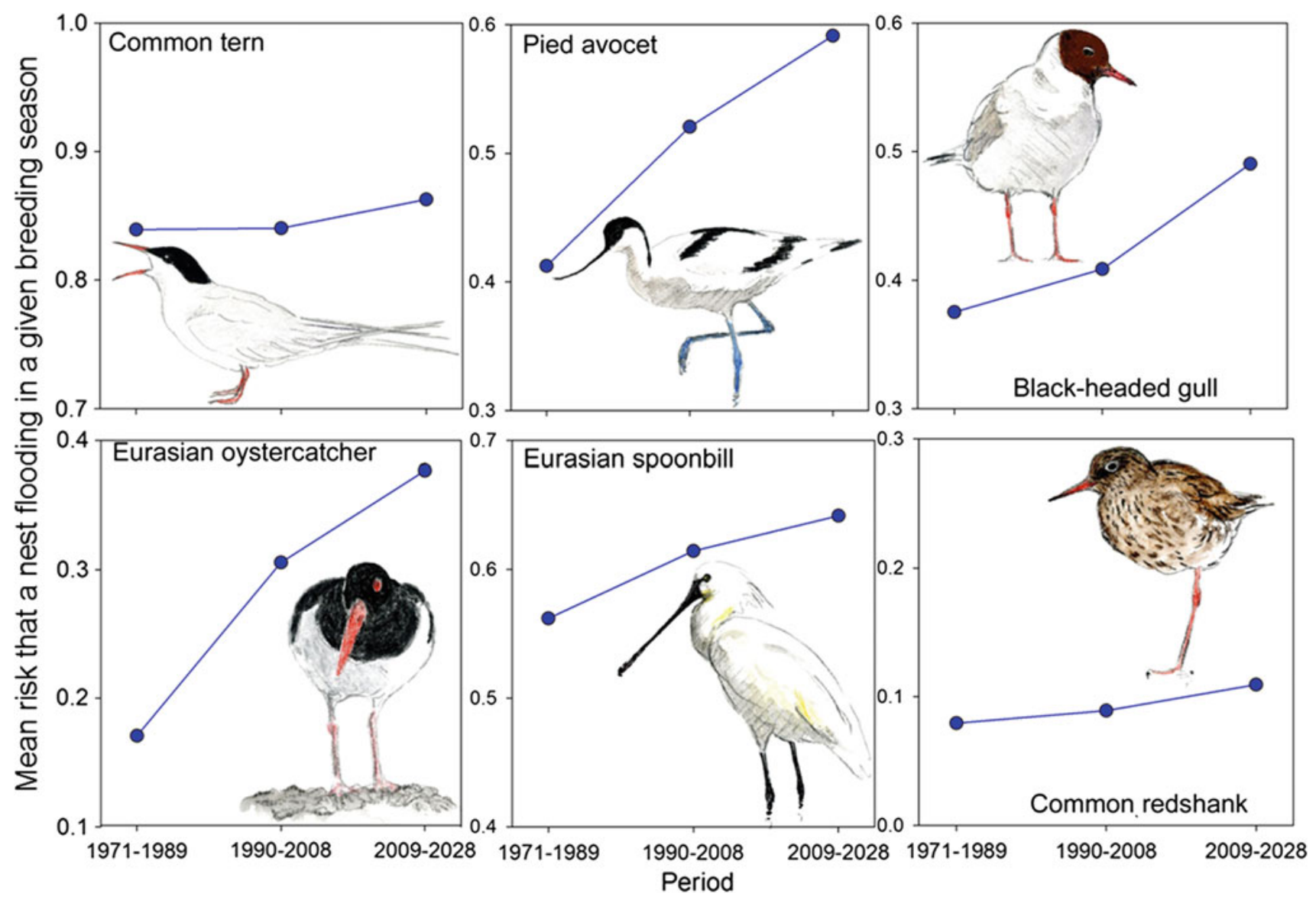

Fig. 9.26 Mean probability that a nest will flood at least once in a given breeding season, calculated for recent years (1990-2008), and projections for earlier (1971-1989) and future periods (2009-2028) based on model projections for sea-level rise and flooding risk that assume birds do not adjust their nest site selection adaptively (Van de Pol et al. 2010a). Please note that the range of the $y$-axis varies between panels and Sparks 1999) and migration (Cotton 2003) have been most widely reported, since adjusting timing is a flexible way to alter the climatic conditions experienced. If birds cannot alter their timing sufficiently or climate change makes historically adaptive cues maladaptive, then populations may suffer (Visser 2008). Focusing on coastal birds, there appears to be no general pattern in how timing of egg laying has responded, with for example northern lapwings Vanellus vanellus showing no response over the past decades, while egg laying in Eurasian oystercatchers Haematopus ostralegus advanced in response to increased rainfall, and in ringed plovers Charadrius hiaticula advanced in response to rising temperatures (Crick and Sparks 1999).

Studies have also identified various cases where interannual variability in demographic rates was associated with climatic variability. The most common pattern is that annual juvenile and/or adult survival is strongly positively related to winter temperatures in many coastal birds (e.g. Peach et al. 1994; Yalden and Pearce-Higgins 1997; Atkinson et al. 2000). By contrast, a review has suggested that populations of nidifugous species (i.e. most waders) might be more strongly influenced by climatic conditions during the breeding season via effects of summer climate on reproduction (Sæther et al. 2004). A specific example of strong effects of summer climate on the reproduction of a community of coastal birds occurs when salt marshes become flooded during periods of strong wind, which can lead to catastrophic failure of a given breeding season. However, the degree to which species are affected by such events depends strongly on their existing nesting preference and elevation (Fig. 9.26), as well as on their potential to respond to increased frequency of summer flooding events (about which virtually nothing is known).

\subsubsection{Changes in Bird Numbers and Distribution}

Although there is some evidence that key life-history traits and demographic rates are changing potentially as a direct 
Fig. 9.27 Schematic illustration of how different aspects of a changing climate affect different demographic rates in Eurasian oystercatchers (Van de Pol et al. 2010a)

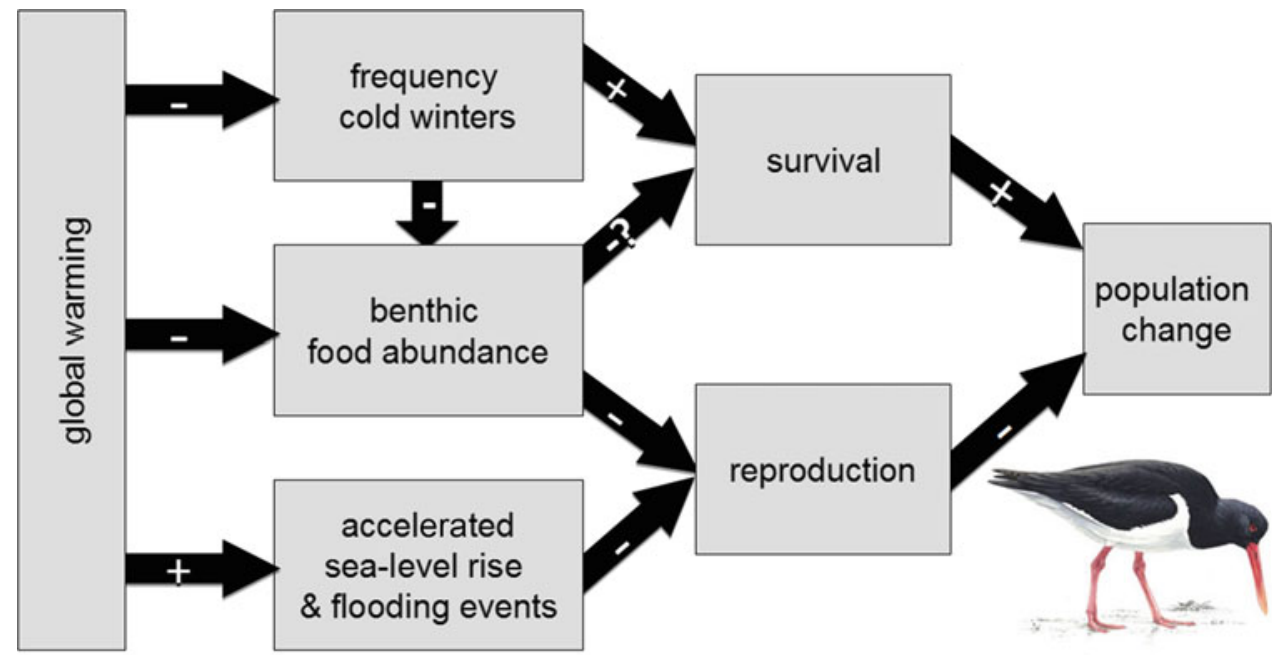

result of changes in climate variables, it remains very difficult to predict from these patterns what the population consequences of a changing climate might be. The reason for this is two-fold. First, many aspects of the weather (temperature, rainfall) are changing and not necessarily at the same rate throughout the year and in the same area. To assess the impact of climate change as a whole it is necessary to have good knowledge of all major climate drivers affecting bird populations. Second, different parts of the life-cycle may be affected by climate change, and not necessarily in the same direction. This implies that to predict how climate change will affect the population size of a species, requires a thorough understanding of which demographic rates are affected and how this in turn will affect population dynamics. In some cases, even strong climate dependency of demographic rates may not necessarily translate into changes in population size, for example in species with strong density-regulation (Reed et al. 2013).

An example of how complex the situation might be is shown in Fig. 9.27 for Eurasian oystercatchers breeding on a salt marsh on the Wadden Sea island of Schiermonnikoog (Van de Pol et al. 2010a, b, 2011). The frequency of exceptionally cold winters is predicted to decrease in this area, which is expected to result in an increase in both juvenile and adult survival. However, these warmer winters are also expected to reduce the benthic food stocks on which oystercatchers rely for their reproduction. Reproduction is expected to be further negatively affected by the flooding events that have become more frequent and higher in recent decades, especially during the breeding season (Figs. 9.25 and 9.26). Taking all these relationships together it is a priori unclear whether the local population will benefit or suffer, and a population model needs to be built that includes effects on demographic rates across the entire life-cycle in order to establish whether oystercatcher numbers are likely to benefit from climate change (Van de Pol et al. 2010b). This example also illustrates that even though reproduction is likely to be negatively affected by climate change, this does not mean that population numbers will also be reduced. Since reproduction and survival might be affected in opposite directions by different aspects of climate change predicting how population numbers will respond is not straightforward. Translating local population dynamics to meta-population dynamics is even more difficult, as climate does not affect all populations equally (e.g. some salt marshes are more susceptible to flooding than others due to geographic variation in elevation and compensatory sedimentation rates; see Sect. 9.6.2)

Finally, most coastal birds are already affected by many other (anthropogenic) threats, such as changes in land use (see, for example, effects of livestock grazing or abandoning on the vegetation of salt marshes in Sect. 9.6), predation, eutrophication, fisheries and disturbance (Koffijberg et al. 2009), and these other threats may interact with or add to the effects of climate change and thus make it difficult to isolate the contribution of climate change to changes in bird numbers (especially if multiple factors change synchronously over time). For example, as illustrated in Fig. 9.28, when looking at the effects of accelerated SLR on the flooding risk and nesting success of birds, the effects of local soil subsidence due to natural gas extraction may act in a similar cumulative way. Alternatively, the effect of changes in land use may interact indirectly with climate-related SLR via an indirect pathway and feedback loop. Specifically, salt marshes grow vertically in response to more frequent flooding due to sedimentation, but the rate of sedimentation increases with vegetation height, which in turn is affected by the land use in terms of mowing or grazing regimes (see Sect. 9.6).

Direct observations of changes in population numbers are another source of information on how coastal bird populations respond to climate change, although due to the lack of knowledge about the underlying demographic mechanisms, it 
Fig. 9.28 Schematic overview of how specific aspects of climate change and other anthropogenic threats may have cumulative or interactive effects on coastal birds (after Van de Pol et al. 2012)



may be difficult to make reliable predictions for the future. Notwithstanding there is now a strong indication that climate fluctuations are a key driver of population dynamics for coastal birds in Europe's largest estuary, the Wadden Sea. For a striking 30 out of 34 migratory species, changes in meta-population numbers were associated with changes in spring temperatures and/or the NAO index (Laursen et al. 2010). However, the direction of the relationship varied widely among species, and it remains unclear why this is the case.

On a larger scale there have been some clear patterns in observed changes in the distribution of coastal birds, which have been largely attributed to global warming (Ens et al. 2009). It was shown for waders wintering in the United Kingdom that warmer winters led to a shift from wintering on the Atlantic coast (where winters are mild, but food is poor), to wintering on the North Sea coast (where winters are generally more severe, but food supplies are higher) (Austin and Rehfisch 2005). The range shift was especially clear in the smaller species that are affected most from energy stress when temperatures are low (Kersten and Piersma 1987). It has also been suggested that milder winters allow coastal bird species with a greater range of characteristics to overwinter in British estuaries, such that changes in abundance and functional diversity of the community of shorebirds may both change, but in different ways. Another more recent analysis of waders wintering in Europe confirmed a shift in the centre of the distribution to the northeast during the past 30 years, in line with milder temperatures in these areas (Maclean et al. 2008). And also in the Wadden Sea estuary more birds remain to overwinter in the eastern part during mild winters and may also depart at an earlier date to their northern breeding grounds when springs are warm (Bairlein and Exo 2007).

Predictions have also been made for coastal breeding populations on a European-scale based on climate envelope models with mostly northward shifts in the distribution of coastal birds (Huntley et al. 2008). Although these models form a useful starting point, they do not consider the adaptive potential of species. In fact, some coastal species such as common redshanks Tringa totanus, black-tailed godwits Limosa limosa, northern lapwings and Eurasian oystercatchers have previously shown that they can be very successful in adapting to new environmental conditions, as evidenced by their extremely successful colonisation of non-coastal agricultural areas over the 21st century (Van de Kam et al. 2004).

\subsection{Conclusions}

\subsubsection{Abiotic Conditions}

Accelerated SLR, and changes in the wave climate, storms, and local sediment availability all affect the abiotic conditions of coastal systems. The relative importance of these climate change effects and how they interact is poorly understood. It is even more difficult to separate effects of climate change from natural dynamics and the human impacts such as dredging. Human impacts on the geomorphology and 
sediment transport in estuaries are very likely to continue in the coming decades, and may supersede, exacerbate or compensate for the potential impacts of climate change. Heavy storms may result in coastal squeeze. This is particularly the case for dunes and salt marshes with a short foreshore, that is, a relatively narrow and steep foreshore.

\subsubsection{Sandy Shores and Dunes}

- The general response of sandy shores to climate change in the coming decades will be difficult (if not impossible) to detect and quantitatively predict as it is most likely to be superseded by local natural and/or human-impacted dynamics. Increased wave heights, storm surges and SLR, coupled with observed steepening of beach profiles and a historical decline in sediment availability due to coastal protection mean less sediment is available to replenish erosion of beach sand.

- Future changes in abiotic conditions of coastal dune systems are more likely to be driven by local anthropogenic impacts and natural variability than attributable directly to climate change. Rate of coastal change is strongly affected by local conditions, such as the effect of offshore bathymetry on inshore wave climate, local sand availability, rather than by regional variability and changes in the wave and wind climate.

\subsubsection{Salt Marshes}

- The SSC of fine-grained material is important for salt marshes to cope with sea-level rise. Salt marshes with a low tidal range and low SSC $\left(<20 \mathrm{mg} \mathrm{l}^{-1}\right)$ are at risk of submergence by average SLR projections. The large tidal ranges $(2-6 \mathrm{~m})$ and generally large SSCs (mostly $>20$ $\mathrm{mg} \mathrm{l}^{-1}$ and up to several hundreds of $\mathrm{mg} \mathrm{l}^{-1}$ ) in estuaries make the risk low for marsh submergence by SLR. This also holds for most mainland marshes with or without sedimentation fields. The risk for marsh subsidence by SLR may be higher for back-barrier salt marshes with lower SSC values and tidal ranges.

- There is no single figure for surface elevation change for entire marshes. The position on the marsh is important: distance to source of suspended sediment, namely, edge of salt marsh or creek. Depressions away from the salt-marsh edge and creeks on back-barrier marshes are vulnerable. Surface elevation change is reduced in older marshes as a result of autocompaction, and in grazed marshes as a result of increased bulk density.

- Knowledge of vertical accretion rates at the scale of catchment areas on salt marshes (creeks with their drainage area) in salt marshes is poorly developed. Minor storm floods contribute strongly to accretion of sediment, but a heavy storm flood storm does not always result in extra accretion, and may even result in less surface elevation change at the low marsh and pioneer zone.

- More intensive process studies are needed to elucidate the linkages between tidal marshes and adjacent estuarine and coastal systems.

- De-embankment of summer polders can help to enlarge the area of salt marshes.

\subsubsection{Plant and Animal Communities}

Plant and animal communities can suffer from habitat loss by coastal squeeze in dunes and salt marshes as a result of high wave energy. This is particularly the case for dunes and salt marshes with a short foreshore. Apart from erosion by storm surges in winter, floodings occurred in summer over past decades with subsequent loss of offspring of breeding birds. Plants and animals are also affected by other aspects of climate change, such as changes in temperature and precipitation and atmospheric deposition of nitrogen. Local populations must deal with invasive species that change competitive interactions. Moreover, natural dynamics such as succession, and management practices such as grazing and mowing have a strong impact on plant and animal communities. The key challenge is not only to identify the exact role of climate change, but also to determine the relative importance of climate change compared to other impacts, and how they might interact.

\subsubsection{Sandy Shores and Dunes}

- On the drier southern North Sea coasts, vegetation of dry dunes will increase in xerophytes and bare sand due to moisture limitation of vascular plants.

- Water levels of dune wetlands are highly sensitive to changes in evapotranspiration and therefore recharge. There is currently little consensus on the effects of climate change but implications for dune slack vegetation could be severe. This is a major knowledge gap.

- Dune groundwater chemistry may become more concentrated with solutes due to lower recharge, or altered chemistry of input waters.

- There are relatively few species-specific climate studies, but most suggest a northward shift in species ranges. At a European-scale this may have few consequences, but distributions within individual countries may change markedly. Changes in climate may favour invasive shrub species such as bird cherry Prunus serotina or Japanese rose Rosa rugosa with subsequent changes in the food web.

- Atmospheric nitrogen deposition is above the critical level for dry and wet dune systems. Nitrogen is available 
in excess and causes increased plant production with subsequent loss of slow-growing plant species. There may be interactions between climate change and the effects of nitrogen deposition, linked to faster growth of competitive species in both situations, and enhanced mineralisation of soil organic matter promoting nutrient availability and leaching of nutrients to groundwater.

\subsubsection{Salt Marshes}

- Minor storm floodings in spring negatively affect breeding birds.

- Plant production is significantly positively related to increased precipitation on salt marshes above MHT. Increased plant production could result in outcompeting low-statured species, and hence a decrease in species richness on marshes with subsequent changes in the food web.

- Some southern species will extend northward as a result of higher temperatures. The number of species extinct or emigrating north is smaller than the number of immigrating from the south. The real change in distribution patterns will differ for different species, for example due to migration rates.

- Atmospheric nitrogen deposition is just below the critical level for salt-marsh communities. When the limiting resource nitrogen is available in excess, plant production can easily increase with higher precipitation and temperature.

Open Access This chapter is distributed under the terms of the Creative Commons Attribution 4.0 International License (http:// creativecommons.org/licenses/by/4.0/), which permits use, duplication, adaptation, distribution and reproduction in any medium or format, as long as you give appropriate credit to the original author(s) and the source, provide a link to the Creative Commons license and indicate if changes were made.

The images or other third party material in this chapter are included in the work's Creative Commons license, unless indicated otherwise in the credit line; if such material is not included in the work's Creative Commons license and the respective action is not permitted by statutory regulation, users will need to obtain permission from the license holder to duplicate, adapt or reproduce the material.

\section{References}

Ablain M, Cazenave A, Valladeau G, Guinehut S (2009) A new assessment of the error budget of global mean sea level rate estimated by satellite altimetry over 1993-2008. Ocean Sci 5:193-201

Albrecht F, Wahl T, Jensen J, Weisse R (2011) Determining sea level changes in the German Bight. Ocean Dyn 61:2037-2050
Allen JRL (1990) Salt-marsh growth and stratification: a numerical model with special reference to the Severn Estuary, southwest Britain. Mar Geol 95:77-96

Allen JRL (2000) Morphodynamics of Holocene salt marshes: a review sketch from the Atlantic and Southern North Sea coasts of Europe. Quat Sci Rev 19:1155-1231

Andresen H, Bakker JP, Brongers M, Heydemann B, Irmler U (1990) Long-term changes of salt marsh communities by cattle grazing. Vegetatio 89:137-148

Arens SM, Geelen L (2006) Dune landscape rejuvenation by intended destabilisation in the Amsterdam water supply dunes. J Coast Res 22:1094-1107

Arens SM, Wiersma J (1994) The Dutch foredunes: inventory and classification. J Coast Res 10:189-202

Arens SM, Mulder JPM, Slings QL, Geelen LHWT, Damsma P (2013) Dynamic dune management, integrating objectives of nature development and coastal safety: Examples from the Netherlands. Geomorphology 199:205-213

Atkinson PW, Clark NA, Clark JA, Bell MC, Dare PJ, Ireland PL (2000) The effects of changes in shellfish stocks and winter weather on shorebird populations: results of a 30-year study on the Wash, England. BTO Res Rep 238

Austin GE, Rehfisch MM (2005) Shifting nonbreeding distributions of migratory fauna in relation to climatic change. Glob Change Biol 11:31-38

Baeyens G, Martínez ML (2004) Animal life on coastal dunes: From exploitation and prosecution to protection and monitoring. In: Martínez ML, Psuty NP (eds) Coastal Dunes: Ecology and Conservation. Ecol Stud 171. Springer

Bairlein F, Exo KM (2007) Climate change and migratory waterbirds in the Wadden Sea. Seriously declining trends in migratory waterbirds: Causes-Concerns-Consequences. Common Wadden Sea Secretariat, Wilhelmshaven

Bakker JP, Bouma TJ, Van Wijnen HJ (2005) Interactions between microorganisms and intertidal plant communities. In: Kristensen K, Kostka JE, Haese RR (eds) Interactions Between Macro- and Microorganisms in Marine Sediments. Coast Estuar Stud 60. American Geophysical Union

Bartholdy J (1997) The backbarrier sediments of the Skallingen peninsula, Denmark. Dan J Geogr 97:11-32

Bartholdy J (2000) Processes controlling import of fine-grained sediment to tidal areas: a simulation model. In: Pye $K$, Allen JRL (eds) Coastal and Estuarine Environments: Sedimentology, Geomorphology and Geoarcheology. Geol Soc, London, Spec publ 175

Bartholdy J (2012) Salt marsh sedimentation. In: Davis RA, Dalrymple RW (eds) Principles of Tidal Sedimentology. Springer

Bartholdy J, Aagaard T (2001) Storm surge effects on a back-barrier tidal flat of the Danish Wadden Sea. Geo Mar Lett 20:133-141

Bartholdy J, Christiansen C, Kunzendorf H (2004) Long term variations in backbarrier salt marsh deposition on the Skallingen peninsula - the Danish Wadden Sea. Mar Geol 203:1-21

Bartholdy J, Pedersen JBT, Bartholdy AT (2010a) Autocompaction in shallow silty salt marsh clay. Sedim Geol 223:310-319

Bartholdy AT, Bartholdy J, Kroon A (2010b) Salt marsh stability and patterns of sedimentation across a backbarrier platform. Mar Geol 278:31-42

Bartholomeus RP, Witte JPM, Runhaar J (2012) Drought stress and vegetation characteristics on sites with different slopes and orientations. Ecohydrology 5:808-818

Bauer S, van Dinther M, Høgda KA, Klaassen M, Madsen J (2008) The consequences of climate-driven stop-over sites changes on migration schedules and fitness of Arctic geese. J Anim Ecol 77:654-660 
Bauer BO, Davidson-Arnott RGD, Hesp PA, Namikas SL, Ollerhead J, Walker IJ (2009) Aeolian sediment transport on a beach: surface moisture, wind fetch, and mean transport. Geomorphology 105:106-116

Beniston M, Stephenson DB, Christensen OB, Ferro CAT, Frei C, Goyette S, Halsnaes K, Holt T, Jylhä K, Koffi B, Palutikof J, Schöll R, Semmler T, Woth K (2007) Future extreme events in European climate: an exploration of regional climate model projections. Clim Change 81:71-95

Berry PM, Jones AP, Nicholls RJ, Vos CC (eds) (2007) Assessment of the vulnerability of terrestrial and coastal habitats and species in Europe to climate change, Annex 2 of Planning for biodiversity in a changing climate - BRANCH project Fin Rep. Natural England

Beukema JJ (1992) Expected changes in the Wadden Sea benthos in a warmer world: Lessons from periods with mild winters. Neth J Sea Res 30:73-79

Beukema JJ, Dekker R (2005) Decline of recruitment success in cockles and other bivalves in the Wadden Sea: possible role of climate change, predation on postlarvae and fisheries. Mar Ecol Prog Ser 287:149-167

Beukema JJ, Dekker R, Jansen J (2009) Some like it cold: populations of the tellinid bivalve Macoma balthica (L) suffer in various ways from a warming climate. Mar Ecol Prog Ser 384:135-145

Bobbink R, Hicks K, Galloway J, Spranger T, Alkemade R, Ashmore M, Bustamante M, Cinderby S, Davidson E, Dentener F, Emmett B, Erisman JW, Fenn M, Gilliam F, Norden A, Pardo L, De Vros W (2010) Global assessment of nitrogen deposition effects on terrestrial plant diversity: a synthesis. Ecol Appl 20:30-59

Boorman LA, Boorman MS (2001) The spatial and temporal effects of grazing on the species diversity of sand dunes. In: Houston JA, Edmondson SE, Rooney PJ (eds) Coastal Dune Management: shared experience of European conservation practice. Liverpool Univ Press

Boorman LA, Goss-Custard JD, McGrortyS (1989). Climate change, rising sea level and the British coast. Natural Environment Research Council. ITE Research Publication 1:1-24

Bos D, Loonen M, Stock M, Hofeditz F, Van Der Graaf S, Bakker JP (2005) Utilisation of Wadden Sea salt marshes by geese in relation to livestock grazing. J Nat Conserv 15:1-15

Bouma TJ, Van Belzen J, Balke T, Zhu Z, Airoldi L, Blight AJ, Davies AJ, Galvan C, Hawkins SJ, Hoggart SPG, Lara JL, Losad IJ, Maza M, Ondivila B, Skov MW, Strain EM, Thompson RC, Yang S, Zanuttigh B, Zhang L, Herman PMJ (2014) Identifying knowledge gaps hampering application of intertidal habitats in coastal protection: Opportunities and steps to take. Coast Eng $87: 147-157$

Broeckx S, Smets S, Liekens I, Bulckaen D, De Nocker L (2011) Designing a long-term flood risk management plan for the Scheldt estuary using a risk-based approach. Natur Haz 57:245-266

Bruun P (1962) Sea level rise as a cause of shore erosion. J Waterw Harb Div, ASCE 88:117-130

Cahoon DR, Reed DJ, Day JW (1995) Estimating shallow subsidence in microtidal salt marshes of the southeastern United States: Kaye and Barghoorn revisited. Mar Geol 128:1-9

Cahoon DR, French JR, Spencer T, Reed D, Möller I (2000) Vertical accretion versus elevational adjustment in UK saltmarshes: an evolution of alternative methodologies. In: Pye K, Allen JRL (eds) Coastal and Estuarine Environments: Sedimentology, Geomorphology and Geoarcheology. Geol Soc Spec Publ 175

Callaghan DP, Bouma TJ, Klaassen PC, Van der Wal D, Stive MJF, Herman PMJ (2010) Hydrodynamic forcing on salt-marsh development: distinguishing the relative importance of waves and tidal flows. Estuar Coast Shelf Sci 89:73-88

Camphuysen CJ, Ens BJ, Heg D, Hulscher JB, van der Meer J, Smit CJ (1996) Oystercatcher Haematopus ostralegus winter mortality in the
Netherlands: the effect of severe weather and food supply. Ardea 84a:469-492

Carter RWG (1991) Near-future sea level impacts on coastal dune landscapes. Landsc Ecol 6:29-39

Chauhan PPS (2009) Autocyclic erosion in tidal marshes. Geomorphology 61:373-391

Chini N, Stansby P, Leake J, Wolf J, Roberts-Jones J, Lowe J (2010) The impact of sea level rise and climate change on inshore wave climate: a case study for East Anglia (UK). Coast Eng 57:973-984

Church JA, White NJ (2006) A $20^{\text {th }}$ century acceleration in global sea-level rise. Geophys Res Lett 33:L01602

Ciais P, Reichstein M, Viovy N, Granier A, Ogee J, Allard V, Aubinet M, Buchmann N, Bernhofer C, Carrara A, Chevallier F, De Noblet N, Friend AD, Friedlingstein P, Grunwald T, Heinesch B, Keronen P, Knohl A, Krinner G, Loustau D, Manca G, Matteucci G, Miglietta F, Ourcival JM, Papale D, Pilegaard K, Rambal S, Seufert G, Soussana JF, Sanz MJ, Schulze ED, Vesala T, Valentini R (2005) Europe-wide reduction in primary productivity caused by the heat and drought in 2003. Nature 437:529-533

Clarke ML, Rendell HM (2009) The impact of North Atlantic storminess on western European coasts: A review. Quat Int 195:31-41

Clarke D, Sanitwong Na Ayutthaya S (2010) Predicted effects of climate change, vegetation and tree cover on dune slack habitats at Ainsdale on the Sefton Coast, UK. J Coast Conserv 14:115-125

Cloern JE (1987) Turbidity as a control on phytoplankton biomass and productivity in estuaries. Cont Shelf Res 7:1367-1381

Cooper NJ, Cooper T, Burd F (2001) 25 years of salt marsh erosion in Essex: Implications for coastal defence and nature conservation. J Coast Conserv 9:31-40

Cotton PA (2003) Avian migration phenology and global climate change. Proc Nat Acad Sci 100:12219-12222

Cowell PJ, Stive MJE, Niederoda AW, DeVriend HJ, Swift DJP, Kaminsky GM, Capobianco M (2003) The Coastal-Tract (part 1): a conceptual approach to aggregated modeling of low-order coastal change. J Coast Res 19:812-827

Cox R, Wadsworth RA, Thomson AG (2003) Long-term changes in salt marsh extent affected by channel deepening in a modified estuary. Cont Shelf Res 23:1833-1846

Crick HQP, Sparks TH (1999) Climate change related to egg-laying trends. Nature 399:423-424

Curreli A, Wallace H, Freeman C, Hollingham M, Stratford C, Johnson H, Jones L (2013) Eco-hydrological requirements of dune slack vegetation and the implications of climate change. Sci Tot Environ 443:910-919

Dargie TCD (1993) Sand dune vegetation survey of Great Britain. Part 2 - Scotland. Peterborough, Joint Nature Conservation Committee

Davy AJ, Bakker JP, Figueroa ME (2009) Human modification of European salt marshes. In: Silliman BR, Grosholz ED, Bertness MD (eds) Human Impacts on Salt Marshes. University of California Press

Davy AJ, Hiscock KM, Jones MLM, Low R, Robins NS, Stratford C (2010) Ecohydrological guidelines for wet dune habitats, phase 2. Protecting the plant communities and rare species of dune wetland systems. Bristol, Environment Agency

De Groot AV, Veeneklaas RM, Bakker JP (2011) Sand in the salt marsh: contribution of high-energy conditions to salt-marsh accretion. Mar Geol 282:240-254

De Leeuw J, Olff H, Bakker JP (1990) Year-to-year variation in salt marsh production as related to inundation and rainfall deficit. Aquat Bot 36:139-151

De Leeuw J, Van Den Dool A, De Munck W, Nieuwenhuize J, Beeftink WG (1991) Factors influencing the soil salinity regime along an intertidal gradient. Estuar Coast Shelf Sci 32:87-97

De Swart HE, Zimmerman JTF (2009) Morphodynamics of tidal inlet systems. Ann Rev Fluid Mech 41:203-229 
De Winter RC (2014) Dune erosion under climate change. PhD Thesis, Utrecht University

De Winter RC, Sterl A, de Vries JW, Weber SL, Ruessink BG (2012) The effect of climate change on extreme waves in front of the Dutch coast. Ocean Dyn 62:1139-1152

De Winter RC, Sterl A, Ruessink BG (2013) Wind extremes in the North Sea Basin under climate change: an ensemble study of 12 CMIP5 GCMs. J Geophys Res: Atmos 118:1601-1612

Diederich S, Nehls G, Beusekom JEE, Reise K (2004) Introduced Pacific oysters (Crassostrea gigas) in the northern Wadden Sea: invasion accelerated by warm summers? Helgol Mar Res 59:97-106

Dijkema KS (1987) Changes in salt-marsh area in the Netherlands Wadden Sea after 1600. In: Huiskes AHL, Blom CWPM, Rozema J (eds) Vegetation between Land and Sea. Junk, Dordrecht

Dijkema KS (1994) Auswirkungen des Meeresspieglanstieges auf die Salzwiesen. In: Lozán JJ, Rachor E, Reise K, Von Westernhage H, Lens W (eds) Warnsignale aus dem Wattenmeer. Blackwell

Dijkema KS (1997) Impact prognosis for salt marshes from subsidence by gas extraction in the Wadden Sea. J Coast Res 13:1294-1304

Dijkema KS, Van Duin WE (2012) 50 jaar monitoring van kwelderwerken. De Lev Natuur 113:118-122

Dijkema KS, Kers AS, Van Duin WE (2010) Salt marshes: applied long-term monitoring. In: Marencic $\mathrm{H}$, Eskildsen $\mathrm{K}$, Farke $\mathrm{H}$, Hedtkamp S (eds) Science for Nature Conservation and Management: The Wadden Sea Ecosystem and EU Directives. Proc $12^{\text {th }}$ Int Sci Wadden Sea Symp Wilhelmshaven, Germany, 30 March - 3 April 2009. Wadden Sea Ecosys 26. Common Wadden Sea Secretariat, Wilhelmshaven

Dijkema KS, van Dobben HF, Koppenaal EC, Dijkman EM, van Duin WE (2011) Kweldervegetatie Ameland 1986-2010: effecten van bodemdaling en opslibbing op NeerlandsReid en De Hon. In: Begeleidingscommissie Monitoring Bodemdaling Ameland. Monitoring Bodemdaling Ameland. Deel 2. Evaluatie na 23 jaar gaswinning

Dillingh D, Baart F, Ronde J de (2012) Do we have to take an acceleration of sea level rise into account? In: EGU general assembly 14. Geophys Res Abst. Munich, EGU (TUD)

DiPol (2012) WP "Risk analysis" SCREMOTOX March 2012. Interreg IVb Report

Doing H (1995) Landscape ecology of the Dutch coast. J Coast Conserv 1:145-172

Donat MG, Leckebusch GC, Pinto JG, Ulbrich U (2010) European storminess and associated circulation weather types: future changes deduced from a multi-model ensemble of GCM simulations. Clim Res 42:27-43

Doody JP (2013) Sand Dune Conservation, Management, and Restoration. Springer

Doody JP, Skarregaard P (2007) Sand dune - Country Report, Denmark. Coastal Wiki, Flanders Marine Institute (VLIZ)

Dronkers J (2005) Dynamics of Coastal Systems. World Scientific

Dyer KR (1997) Estuaries: A Physical Introduction. Wiley

EEA (2012) Climate changes impacts and vulnerability in Europe 2012. EEA report 12/2012. European Environment Agency (EEA), Copenhagen

Elschot K, Bouma TJ, Temmerman S, Bakker JP (2013) Effects of long-term grazing on sediment deposition and salt-marsh accretion. Estuar Coast Shelf Sci 133:109-115

Emmett BA, Beier C, Estiarte M, Tietema A, Kristensen HL, Williams D, Penuelas J, Schmidt I, Sowerby A (2004) The response of soil processes to climate change: Results from manipulation studies of shrublands across an environmental gradient. Ecosystems 7:625-637

Ens BJ, Blew J, Roomen MWJ, van Turnhout CAM (2009) Exploring contrasting trends of migratory waterbirds in the Wadden Sea. Common Wadden Sea Secretariat, Trilateral Monitoring and
Assessment Group, Joint Monitoring Group of Migratory Birds in the Wadden Sea, Wilhemshaven

Erchinger HF (1985) Dünen, Watt und Salzwiesen. Das Niedersächsische Ministerium für Ernährung, Landwirtschaft und Forsten. Hannover

Esselink P, Chang ER (2010) Kwelderherstel Noard-Fryslân Bûtendyks: invloed van stormactiviteit op zes jaar proefverkweldering. Rapport 01. PUCCIMAR Ecologisch Onderzoek \& Advies

Esselink P, Dijkema KS, Reents S, Hageman G (1998) Vertical accretion and profile changes in abandoned man-made tidal marshes in the Dollard estuary, the Netherlands. J Coast Res 14:570-582

Esselink P, Petersen J, Arens S, Bakker JP, Bunje J, Dijkema KS, Hecker N, Hellwig AV, Jensen B, Kers B, Körber P, Lammerts EJ, Lüerssen G, Marencic H, Stock M, Veeneklaas RM, Vreeken M, Wolters M (2009) Salt Marshes. Thematic Report 8. In: Marencic H, De Vlas J (eds) Wadden Sea Quality Status Report 2009.Wadden Sea Ecosystems 25. Common Wadden Sea Secretariat, Wilhelmshaven

Esselink P, Bos D, Oost AP, Dijkema KS, Bakker R, De Jong R (2011) Verkenning afslag Eems-Dollardkwelders. PUCCIMAR Ecologisch Onderzoek en Advies, Altenburg \&Wymenga ecologisch onderzoek, Vries

European Commission (1992) COUNCIL DIRECTIVE 92/43/EEC of 21 May 1992, on the conservation of natural habitats and of wild fauna and flora

Eurosion (2004) Living with coastal erosion in Europe: sediment and space for sustainability. Online through www.eurosion.org/reportonline/reports.html. Accessed May 2013

Feagin RA, Sherman DJ, Grant WE (2005) Coastal erosion, global sea-level rise, and the loss of sand dune plant habitats. Front Ecol Env 3:359-364

Flemming BW, Bartholomä A (1997) Response of the Wadden Sea to a rising sea level: a predictive empirical model. Deut Hydrogr Z 49:343-353

French JR (1993) Numerical simulation of vertical marsh growth and adjustment to accelerated sea-level rise, North Norfolk. Earth Surf Proc Landf 18:63-81

French J (2006a) Tidal marsh sedimentation and resilience to environmental change: Exploratory modelling of tidal, sea-level and sediment supply forcing in predominantly allochthonous systems. Mar Geol 235:119-136

French PW (2006b) Managed realignment - The developing story of a comparatively new approach to soft engineering. Estuar Coast Shelf Sci 67:409-423

French JR, Spencer T (1993) Dynamics of sedimentation in a tidal-dominated backbarrier salt marsh, Norfolk. Mar Geol 110:315-331

Friedrichs CT, Aubrey DG (1994) Tidal propagation in strongly convergent channels. J Geophys Res 99:3321-3336

Grabemann I, Weisse R (2008) Climate change impact on extreme wave conditions in the North Sea: and ensemble study. Ocean Dyn 58:199-212

Grootjans AP, Adema EB, Bekker RM, Lammerts EJ (2004) Why coastal dune slacks sustain a high biodiversity. In: Martinez ML, Psuty NP (eds) Coastal Dunes: Ecology and Conservation. Ecological Studies. Springer

Hadley D (2009) Land use and coastal zone. Land Use Pol 26S:198203

Haigh I, Nicholls R, Wells N (2011) Rising sea levels in the English Channel 1990-2100. Proc ICE Mar Eng 164:81-92

Hall J, Emmett B, Garbutt A, Jones L, Rowe E, Sheppard L, Vanguelova E, Pitman R, Britton A, Hester A, Ashmore M, Power S, Caporn S (2011) UK Status Report July 2011: Update to empirical critical loads of nitrogen. Report to Defra under contract AQ801 Critical Loads and Dynamic Modelling Report date: 5th 
July 2011. Available online at: http://cldm.defra.gov.uk/PDFs/UK status_report_2011_finalversion_July2011_v2.pdf

Harrison PA, Berry PM, Dawson TP (2001) Climate Change and Nature Conservation in Britain and Ireland: Modelling natural resource responses to climate change (the MONARCH project). UKCIP Tech Rep, Oxford

Herrier JL (2008) Sand dune - Country Report, Belgium. In: Doody JP (ed) Euromarine Consortium Wiki. www.euromarineconsortium.eu/ wiki/Sand_dune_-_Country_Report,_Belgium

Honkoop PJ, Beukema J (1997) Loss of body mass in winter in three intertidal bivalve species: an experimental and observational study of the interacting effects between water temperature, feeding time and feeding behaviour. J Exper Mar Biol Ecol 212:277-297

Hötker H, Segebade A (2000) Effects of predation and weather on the breeding success of Avocets Recurvirostra avosetta. Bird Study 47:91-101

Hulme M, Jenkins G, Lu X et al, UKCIP (2002) Climate change scenarios for the United Kingdom: the UKCIP02 scientific report. Norwich, Tyndall Centre for Climate Change Research. School of Environmental Sciences. University of East Anglia

Huntley B, Collingham YC, Willis SG, Green RE (2008) Potential impacts of climatic change on European breeding birds. PLOS ONE 3. doi:10.1371/journal.pone.0001439

Irmler U, Heller K, Meyer H, Reineke HD (2002) Zonation of ground beetles (Coleoptera: Carabidae) and spiders (Araneida) in salt marshes at the North and Baltic Sea and the impact of the predicted sea level increase. Biodiv Conserv 7:1129-1147

Isermann M (2008) Expansion of Rosa rugosa and Hippophae rhamnoides in coastal grey dunes: effects at different scales. Flora 203:273-280

Jefferies RL, Perkins N (1977) The effects on the vegetation of the additions of inorganic nutrients to salt marsh soils at Stiffkey, Norfolk. J Ecol 65:867-882

Jensen J, Mudersbach C (2004) Zeitliche Änderungen in den Wasserstandzeitreihen an den deutschen Küsten. Klimaänderung und Küstenschutz. Hamburg, Proceedings Universität Hamburg:1-15

Jentsch A, Kreyling J, Beierkuhnlein C (2007) A new generation of climate-change experiments: events, not trends. Front Ecol Env 5:365-374

Jones MLM, Hayes F, Brittain SA, Haria S, Williams PD, Ashenden TW, Norris DA, Reynolds B (2002) Changing nutrient budget of sand dunes: Consequences for the nature conservation interest and dune management. 2. Field Survey. CCW Contract No: FC 73-01-347. CEH Project No: C01919

Jones MLM, Wallace H, Norris DA, Brittain SA, Haria S, Jones RE, Rhind PM, Williams PD, Reynolds B, Emmett BA (2004) Changes in vegetation and soil characteristics in coastal sand dunes along a gradient of atmospheric nitrogen deposition. Plant Biol 6:598-605

Jones MLM, Sowerby A, Williams DL, Jones RE (2008) Factors controlling soil development in sand dunes: evidence from a coastal dune soil chronosequence. Plant and Soil 307:219-234

Jones MLM, Norman K, Rhind PM (2010) Topsoil inversion as a restoration measure in sand dunes, early results from a UK field-trial. J Coast Conserv 14:139-151

Jones MLM, Angus S, Cooper A, Doody P, Everard M, Garbutt A, Gilchrist P, Hansom G, Nicholls R, Pye K, Ravenscroft N, Rees S, Rhind P, Whitehouse A (2011) Coastal margins. In: UK National Ecosystem Assessment. Understanding nature's value to society. Cambridge, Tech Rep. UNEP-WCMC

Kamps LF (1962) Mud distribution and land reclamation in the eastern Wadden Sea shallows. Rijkswaterstaat Communications 4. Den Haag

Katsman C, Hazelager W, Drijfhout S, Van Oldenborgh G, Burgers G (2008) Climate scenarios of sea level rise for the northeast Atlantic ocean: a study including the effects of ocean dynamics and gravity changes induced by ice melt. Clim Change 91:351-374

Katsman CA, Sterl A, Beersma JJ, van den Brink HW, Church JA, hazeleger W, kopp RE, Kroon D, Kwadijk J, et al (2011) Exploring high-end scenarios for local sea level rise to develop flood protection strategies for a low-lying delta - the Netherlands as an example. Clim Change 109:617-645

Kearny MS, Rogers AS, Townshend JRG, Rizzo E, Stutzer D (2002) Landsat imagery shows decline of coastal marshes in Chesapeake and Delaware bays. EOS Trans Am Geophys Union 83:177-178

Keijsers JGS, Poortinga A, Riksen MJPM, Maroulis J (2014) Spatio-temporal variability in accretion and erosion of coastal foredunes in the Netherlands: regional climate and local topography. PLOS One 9,3:e91115. doi:10.1371/journal.pone.0091115

Kersten M, Piersma T (1987) High levels of energy expenditure in shorebirds: metabolic adaptations to an energetically expensive way of life. Ardea 75:175-187

Kiehl K, Eischeid I, Gettner S, Walter J (1996) The impact of different sheep grazing intensities on salt-marsh vegetation in Northern Germany. J Veget Sci 7:99-106

Kirwan ML, Guntenspergen GR, D’Alpaos A, Morris JT, Mudd SM, Temmerman S (2010) Limits on the adaptability of coastal marshes to rising sea level. Geophys Res Lett 37:L23401

Knippertz P, Ulbrich U, Speth P (2000) Changing cyclones and wind speeds over the North Atlantic and Europe in a transient GHG experiment. Clim Res 15:109-122

KNMI (2014) KNMI'14 Climate Scenarios for the Netherlands: A guide for professionals in climate adaptation. KNMI, De Bilt, The Netherlands

Knutson TR, McBride JL, Chan J, Emanuel K, Holland G, Landsea C, Held I, Kossin JP, Srivastava AK, Sugi M (2010) Tropical cyclones and climate change. Nat Geosci 3:157-163

Koffijberg K, Dijksen L, Hälterlein B, Laursen K, Potel P, Schrader S (2009) Thematic Report 8. Breeding birds. In: Marencic H, De Vlas J (eds) Wadden Sea Quality Status Report 2009.Wadden Sea Ecosystems 25. Common Wadden Sea Secretariat, Wilhelmshaven Kooijman AM, Van der Meulen F (1996) Grazing as a control against 'grass-encroachment' in dry dune grasslands in The Netherlands. Land Urb Plan 34:323-333

Kooijman AM, Van der Hagen HGJM, Noordwijk H (2012) Stikstof depositie in de duinen: alles in beeld? Landschap 29:147-154

Kuijper DPJ, Bakker JP (2012) Vertebrate below- and above-ground herbivory and abiotic factors alternate in shaping salt-marsh plant communities. J Exp Mar Biol Ecol 432-433:17-28

Langner J, Bergström R, Foltescu V (2005) Impact of climate change on surface ozone and deposition of sulphur and nitrogen in Europe. Atmos Env 39 1129-1141

Laursen K, Blew J, Eskildsen K, Günther K, Hälterlein B, Kleefstra R, Lüerßen G, Potel P, Schrader S (2010) Migratory Waterbirds in the Wadden Sea 1987-2008. Common Wadden Sea Secretariat, Wilhelmshaven

Leckebusch GC, Ulbrich U (2004) On the relationship between cyclones and extreme windstorm events over Europe under climate change. Glob Plan Change 44:181-193

Levine JM, McEachern AK, Cowan C (2008) Rainfall effects on rare annual plants. J Ecol 96:795-806

Linderholm HW (2006) Growing season changes in the last century. Agric Forest Meteor 137:1-14

Lowe JA, Gregory JM (2005) The effects of climate change on storm surges around the United Kingdom. Phil Trans R Soc A 363: $1313-1328$

Maclean IMD, Austin GE, Rehfisch MM, Blew J, Crowe O, Delany S, Devos K, Deceuninck B, Günther K, Laursen K, van Roomen M, Wahl J (2008) Climate change causes rapid changes in the 
distribution and site abundance of birds in winter. Glob Change Biol 14:2489-2500

Mariotti G, Fagherazzi S (2010) A numerical model for the coupled long-term evolution of salt marshes and tidal flats. J Geophys Res 115:F01004

Maris T, Cox T, Temmerman S, De Vleeschauwer P, Van Damme S, De Mulder T, Van den Bergh E, Meire P (2007) Tuning the tide: creating ecological conditions for tidal marsh development in a flood control area. Hydrobiologia 588:31-43

Mayerhofer P, de Vries B, den Elzen M, van Vuuren D, Onigkeit J, Posch M, Guardans R (2002) Long-term, consistent scenarios of emissions, deposition, and climate change in Europe. Env Sci Pol 5:273-305

Meire P, Ysebaert T, Van Damme S, Van den Bergh E, Maris T, Struyf E (2005) The Scheldt estuary: a description of a changing ecosystem. Hydrobiologia 540:1-11

Mendez V, Gill JA, Burton NHK, Austin GE, Petchey OL, Davies RG (2012) Functional diversity across space and time: trends in wader communities on British estuaries. Divers Distrib 18:356-365

Metzing D (2010) Global warming changes the terrestrial flora of the Wadden Sea. In: Marencic H, Eskilldsen K, Farke H, Hedtkamp S (eds) Science for Nature conservation and Management: the Wadden Sea Ecosystem and EU Directives. Proc $12^{\text {th }}$ Sci Wadden Sea Symp, 30 March - 3 April 2009. Wilhelmshaven. Wadden Sea Ecosys 26:211-215

Moeslund JE, Arge L, Bøcher PK, Nygaard B, Svenning JC (2011) Geographically comprehensive assessment of salt-meadow vegetation-elevation relation using LIDAR. Wetlands 31:471-482

Möller I (2006) Quantifying saltmarsh vegetation and its effect on wave height dissipation: Results from a UK east coast saltmarsh. Estuar Coast Shelf Sci 69:337-51

Møller AP, Fiedler W, Berthold P (2010) Effects of climate change on birds. Oxford University Press

Möller I, Kudella M, Rupprecht F, Spencer T, Paul M, Van Wesenbeeck B, Wolters G, Jensen K, Bouma TJ, Miranda-Lange M, Schimmels S (2014) Wave attenuation over coastal salt marshes under storm surge conditions. Nat Geosci 7:727-731

Nicholls RJ, Cazenave A (2010) Sea-level rise and its impact on coastal zones. Science 328:1517-1520

Niemeyer HD (2015) Effekte des Klimawandels auf Randbedingungen im Insel- und Küstenschutz -gegenwärtige und $\mathrm{zu}$ erwartende Trends. [Effects of climate change on boundary conditions for coastal protection - current and expected trends] Ber Forschungsstelle Küste 44:1-55

Nolte S, Koppenaal EC, Esselink P, Dijkema KS, Schürch M, De Groot AV, Bakker JP, Temmerman S (2013a) Measuring sedimentation in tidal marshes: A review on methods and their applicability in biogeomorphological studies. J Coast Conserv 17:301-325

Nolte S, Müller F, Schuerch M, Wanner A, Esselink P, Bakker JP, Jensen K (2013b) Does livestock grazing influence salt marsh resilience to sea-level rise in the Wadden Sea? Estuar Coast Shelf Sci 135:296-305

Norris K, Cook T, O'Dowd B, Durdin C (1997) The density of Redshank Tringa tetanus breeding on the salt marshes of the Wash in relation to habitat and its grazing management. $\mathrm{J}$ Appl Ecol 34:999-1013

Olff $\mathrm{H}$, de Leeuw J, Bakker JP, Platerink RJ, van Wijnen HJ, de Munck W (1997) Vegetation succession and herbivory in a salt marsh: changes induced by sea-level rise and silt deposition along an elevational gradient. J Ecol 85:799-814

Oost A, Kabat P, Wiersma A, Hofstede J (2009) Climate Change Thematic Report No.4.1. In: Marencic H, De Vlas J (eds) Wadden Sea Quality Status Report 2009.Wadden Sea Ecosystems 25 Common Wadden Sea Secretariat, Wilhelmshaven
Paarlberg AJ, Knaapen MAF, De Vries MB, Hulscher SJMH, Wang ZB (2005) Biological influences on morphology and bed composition of an intertial flat. Estuar Coast Shelf Sci 64:577-590

Peach WJ, Thompson PS, Coulson JC (1994) Annual and long-term variation in the survival rates of British Lapwings Vanellus vanellus. J Anim Ecol 63:60-70

Pedersen JBT, Bartholdy J (2006) Budgets for fine-grained sediment in the Danish Wadden Sea. Mar Geol 235:101-117

Pejrup M, Larsen M, Edelvang K (1997) A fine-grained sediment budget for the Syly-Rømø tidal basin. Helg Meeresunt 51:253-268

Phelan N, Shaw A, Baylis A (2011) The extent of saltmarsh in England and Wales. Environmental Agency, Bristol

Pilkey OH, Cooper JAG (2004) Society and sea level rise. Science 303:1781-1782

Poesen J, Nachtergaele J, Vertstraeten G, Valentin C (2003) Gully erosion and environmental change: importance and research needs. Catena 50:91-133

Pohlmann T, Puls W (1993) Currents and transport in water. In: Sünderman J (ed) Circulation and Contaminant Fluxes in the North Sea. Springer

Postma H (1954) Hydrography of the Dutch Wadden Sea, a study of the relation between water movement, the transport of suspended materials and the production of organic matter. Arch Néerland Zool $\mathrm{X}: 406-511$

Postma H (1961) Transport and accumulation of suspended matter in the Dutch Wadden Sea. Netherl J Sea Res 1:148-190

Postma H (1967) Sediment transport and sedimentation in the estuarine environment. In: Lauf H (ed) Estuaries. Am Assoc Adv Sci Publ 83:158-179

Prandle D (2004) How tides and river flows determine estuarine bathymetries. Progr Oceanogr 61:1-26

Provoost S, Jones MLM, Edmondson SE (2011) Changes in landscape and vegetation of coastal dunes in northwest Europe: a review. J Coast Conserv 15:207-26

Psuty NP, Silveira TM (2010) Global climate change: an opportunity for coastal dunes? J Coast Conserv 14:153-160

Pye K (2001) Long-term geomorphological changes and how they may affect the dune coasts of Europe. In: Houston JA, Edmondson SE, Rooney PJ (eds) Coastal Dune Management: shared experience of European conservation practice. Liverpool University Press

Radley GP (1994) Sand dune vegetation survey of Great Britain - Part 1. England. Joint Nature Conservation Committee, Peterborough

Ranasinghe R, Callaghan D, Stive MJF (2012) Estimating coastal recession due to sea level rise: beyond the Bruun rule. Clim Change 110:561-574

Reed DJ (1988) Sediment dynamics and deposition in a retreating coastal salt marsh. Estuar Coast Shelf Sci 26:67-79

Reed TE, Grøtan V, Jenouvrier S, Sæther BE, Visser ME (2013) Population growth in a wild bird is buffered against phenological mismatch. Science 340:488-491

Reineck HE (1980) Sedimentationsbeiträge und Jahresschichtung in einem marinen Einbruchsgebiet/Nordsee. Senckenb Mar 12:380-309

Risely K, Massimo D, Johnston A, Newson SE, Eaton MA, Musgrove AJ, Noble DG, Adams DC, Baillie SR (2012) The Breeding Bird Survey 2011. British Trust for Ornithology

Rosati JD, Dean RG, Walton TL (2013) The modified Bruun Rule extended for landward transport. Mar Geol 340:71-81

Ruessink BG, Jeuken MCJL (2002) Dunefoot dynamics along the Dutch coast. Earth Surf Proc Landf 27:1043-1056

Rustad LE, Campbell JL, Marion GM, Norby RJ, Mitchell MJ, Hartley AE, Cornelissen JHC, Gurevitch J (2001) A meta-analysis of the response of soil respiration, net nitrogen mineralization, and aboveground plant growth to experimental ecosystem warming. Oecologia 126:543-562 
Sæther BE, Sutherland WJ, Engen S (2004) Climate influences on avian population dynamics. Adv Ecol Res 35:185-209

Schlacher TA, Dugan J, Schoeman DS, Lastra M, Jones A (2007) Sandy beaches at the brink. Divers Distrib 13:556-560

Schröder HK, Kiehl K, Stock M (2002) Directional and non-directional vegetation changes in a temperate salt marsh in relation to biotic and abiotic factors. Appl Veget Sci 5:33-44

Schückel U, Kröncke I (2013) Temporal changes in intertidal macrofauna communities over eight decades: A result of eutrophication and climate change. Estuar Coast Shelf Sci 117:210-218

Schuerch M, Vafeidis A, Slawig T, Temmerman S (2013) Modeling the influence of changing storm patterns on the ability of a salt marsh to keep pace with sea level rise. J Geophys Res: Earth Surf 118:1-13

Seminara G, Lanzoni S, Bolla Pittaluga M, Solari L (2001) Estuarine patterns: an introduction to their morphology and mechanics. Lect Notes Phys 582:455-499

Silva H, Dias JM, Caçador I (2009). Is the salt marsh vegetation a determining factor in the sedimentation process? Hydrob 621:33-47

Skov F, Nygaard B, Wind P, Borchsenius F, Normand S, Balslev H, Flojgaard C, Svenning JC (2009) Impacts of $21^{\text {st }}$ century climate changes on flora and vegetation in Denmark. Beyond Kyoto: addressing the challenges of climate change. IOP Publishing. IOP Conf Ser: Earth Env Sci 8

Sterl A, Severijns C, Dijkstra H, Hazeleger W, van Oldenborgh GJ, van den Broeke M, Rugers G, van den Hurk B, van Leeuwen PJ, van Velthoven P (2008) When can we expect extremely high surface temperatures. Geophys Res Lett L14703. doi:10.1029/ 2008GL034071

Stock M (2011) Patterns in surface elevation change across a temperate salt marsh platform in relation to sea-level rise. Coastl Reps 17:33-48

Suchrow S, Pohlman M, Stock M, Jensen K (2012) Long-term surface elevation change in German North Sea salt marshes. Estuar Coast Shelf Sci 98:75-83

Syvitski JPM, Vorosmarty CJ, Kettner AJ, Green P (2005) Impact of humans on the flux of terrestrial sediment to the global ocean. Science 308:376-380

Taylor JA, Murdock AP, Pontee NI (2004) A macroscale analysis of coastal steepening around the coast of England and Wales. Geograph J 170:179-188

Temmerman S, Govers G, Meire P, Wartel S (2003) Modelling long-term tidal marsh growth under changing tidal conditions and suspended sediment concentrations, Scheldt estuary, Belgium. Mar Geol 193:151-169

Temmerman S, Govers G, Wartel S, Meire P (2004) Modelling estuarine variations in tidal marsh sedimentation: response to changing sea level and suspended sediment concentrations. Mar Geol 212:1-19

Temmerman S, Meire P, Bouma TJ, Herman PMJ, Ysebaert T, De Vriend HJ (2013) Ecosystem-based coastal defence in the face of global change. Nature 504:79-83

Townend I (2005) An examination of empirical stability relationships for UK estuaries, J Coast Res 21:1042-1053

Tsoar H (2005) Sand dunes mobility and stability in relation to climate. Physica A 357:50-56

Turner RK, Burgess D, Hadley D, Coombes E, Jackson NA (2007) A cost-benefit appraisal of coastal managed realignment policy. Global Env Change 17:397-407

Uncles RJ, Stephens JA, Smith RE (2002) The dependence of estuarine turbidity on tidal intrusion length, tidal range and residence time. Cont Shelf Res 22:1835-1856

Van de Kam J, Ens BJ, Piersma T, Zwarts L (2004) Shorebirds: An illustrated behavioural ecology. KNNV, Utrecht
Van de Koppel J, Huisman J, Van der Wal R, Olff H (1996) Patterns of herbivory along a productivity gradient: an empirical and theoretical investigation. Ecology 77:736-745

Van de Koppel J, Herman PMJ, Thoolen P, Heip CHR (2001) Do alternate stable states occur in natural ecosystems? Evidence from a tidal flat. Ecology 82:3449-3461

Van de Koppel J, Van der Wal D, Bakker JP, Herman PMJ (2005) Self-organisation and vegetation collapse in salt marsh ecosystems. Amer Natural 165:E1-E12

Van de Pol M, Ens BJ, Heg D, Brouwer L, Krol J, Maier M, Exo KM, Oosterbeek K, Lok T, Eising CM, Koffijberg K (2010a) Do changes in the frequency, magnitude and timing of extreme climatic events threaten the population viability of coastal birds? J Appl Ecol 47:720-730

Van de Pol M, Vindenes Y, Sæther BE, Engen S, Ens BJ, Oosterbeek K, Tinbergen JM (2010b) Effects of climate change and variability on population dynamics in a long-lived shorebird. Ecology 91:1192-1204

Van de Pol M, Vindenes Y, Sæther BE, Engen S, Ens BJ, Oosterbeek K, Tinbergen JM (2011) Poor environmental tracking can make extinction risk insensitive to the colour of environmental noise. Proc Roy Soc B 278:3713-3722

Van de Pol M, Ens BJ, Bakker JP, Esselink P (2012) Sea-level rise and increasing flooding risk of saltmarsh breeding birds. De Lev Nat 113:123-128

Van der Wal D, Pye K (2004) Patterns, rates and possible causes of saltmarsh erosion in the Greater Thames area (UK). Geomorphology 61:373-391

Van der Wal D, Wielemaker-Van den Dool A, Herman PMJ (2008) Spatial patterns, rates and mechanisms of saltmarsh cycles (Westerschelde, The Netherlands). Estuar Coast Shelf Sci 76:357-368

Van Dobben HF, Slim PA (2012) Past and future plant diversity of a coastal wetland driven by soil subsidence and climate change. Clim Change 110:597-618

Van Leussen W (2011) Macroflocs, fine-grained sediment transports, and their longitudinal variations in the Ems estuary. Ocean Dyn 61:387-401

Van Maanen B, Coco G, Bryan KR (2013) Modelling the effects of tidal range and initial bathymetry on the morphological evolution of tidal embayments. Geomorphology 191:23-34

Van Oldenborgh GJ, Collins M, Arblaster JM, Christensen JH, Marotzke J, Power SB, Rummukainen M, Zhou T (2013) IPCC 2013: Annex I: Atlas of global and regional climate projections. In: Stocker TF, Qin D, Plattner GK, Tignor M, Allen SK, Boschung J, Nauels A, Xia Y, Bex V, Midgley PM (eds) Climate Change 2013: The Physical Science Basis. Contribution of Working Group I to the Fifth Assessment Report of the Intergovernmental Panel on Climate Change. Cambridge University Press

Van Straaten LMJU, Kuenen PHH (1957) Accumulation of fine-grained sediments in the Dutch Wadden Sea. Geol Mijnbouw 19:329-354

Van Straaten LMJU, Kuenen PHH (1958) Tidal action as a cause of clay accumulation. J Sedim Petrol 28:406-413

Van Vliet MTH, Zwolsman JJG (2008) Impact of summer droughts on the water quality of the Meuse river J Hydrol 353:1-17

Van Wijnen HJ, Bakker JP (2000) Annual nitrogen budget of a temperate coastal barrier salt-marsh system along a productivity gradient at low and high marsh elevation. Persp Plant Ecol Evol Sys 3:128-141

Van Wijnen HJ, Bakker JP (2001) Long-term surface elevation changes in salt marshes: a prediction of marsh response to future sea-level rise. Estuar Coast Shelf Sci 52:381-390 
Van Wijnen HJ, Bakker JP, De VriesY (1997) Twenty years of salt marsh succession on a Dutch coastal barrier island. J Coast Conserv 3:9-18

Vandenbohede A, Luyten K Lebbe L (2008) Effects of global change on heterogeneous coastal aquifers: A case study in Belgium. J Coast Res 24:160-170

Vandenbruwaene W, Maris T, Cox TJS, Cahoon DR, Meire P, Temmerman S (2011) Sedimentation and response to sea-level rise of a restored marsh with reduced tidal exchange: Comparison with a natural tidal marsh. Geomorphology 130:115-126

Veeneklaas RM, Dijkema KS, Hecker N, Bakker JP (2013) Spatio-temporal dynamics of the invasive plant species Elytrigia atherica on natural salt marshes. Appl Veget Sci 16:205-216

Vestergaard P (1997) Possible impact of sea-level rise on some habitat types at the Baltic coast of Denmark. J Coast Conserv 3:103-112

Visser ME (2008) Keeping up with a warming world; assessing the rate of adaptation to climate change. Proc Roy Soc B 275:649-659

Wahl T, Jense J, Frank T, Haigh ID (2011) Improved estimates of mean sea level changes in the German Bight over the last 166 years. Ocean Dyn 61:701-715

Wahl T, Haigh ID, Woodworth PL, Albrecht F, Dillingh D, Jensen J, Nicholls RJ, Weisse R, Wöppelmann G (2013) Observed mean sea level changes around the North Sea coastline from 1800 to present. Earth Sci Rev 124:51-67

Weisse R, von Storch H, Niemeyer HD, Knaack H (2012) Changing North Sea storm surge climate: An increasing hazard? Ocean Coast Manage 68:58-68

Winiwarter W, Hettelingh JP, Bouwman AF et al (2011) Future scenarios of nitrogen in Europe. In: Sutton MA, Howard CM, Erisman JW et al (eds) The European Nitrogen Assessment. Cambridge University Press
Winterwerp JC (2011) Fine sediment transport by tidal asymmetry in the high-concentrated Ems River: indications for a regime shift in response to channel deepening. Ocean Dyn 61:203-215

Witte JPM, Runhaar J, van Ek R, van der Hoek DCJ, Bartholomeus RP, Batelaan O, van Bodegom PM, Wassen MJ, van der Zee SEATM (2012) An ecohydrological sketch of climate change impacts on water and natural ecosystems for the Netherlands: bridging the gap between science and society. Hydrol Earth Sys Sci 16:3945-3957

Wolff WJ (1992) The end of a tradition - 1000 years of embankment and reclamation of wetlands in the Netherlands. Ambio 21:287-291

Wolters M, Bakker JP, Bertness M, Jefferies RL, Möller I (2005a) Saltmarsh erosion and restoration in south-east England: squeezing the evidence requires realignment. J Appl Ecol 42:844-851

Wolters M, Garbutt A, Bakker JP (2005b). Salt-marsh restoration: evaluating the success of de-embankments in north-west Europe. Biol Conserv 123:249-268

Wood R, Widdows J (2002) A model of sediment transport over an intertidal transect, comparing the influences of biological and physical factors. Limnol Oceanogr 47:848-855

Wood R, Widdows J (2003) Modelling intertidal sediment transport for nutrient change and climate change scenarios. Sci Tot Environ 314:637-649

Woodworth P, Teferle F, Binley R, Shennan I, Williams S (2009) Trends in UK mean sea level revisited. Geophys J Int 176:19-30

Yalden DW, Pearce-Higgins JW (1997) Density-dependence and winter weather as factors affecting the size of a population of Golden Plovers Pluvialis apricaria. Bird Study 44:227-234

Yizhaq H, Ashkenazy Y, Tsoar H (2007) Why do active and stabilized dunes coexist under the same climatic conditions? Phys Rev Lett 98:188001 